\title{
Physical, Chemical, and Biological Characteristics of Pueblo Reservoir, Colorado, 1985-89
}

by Michael E. Lewis and Patrick Edelmann

U.S. GEOLOGICAL SURVEY

Water-Resources Investigations Report 94-4097

Prepared in cooperation with the

PUEBLO BOARD OF WATER WORKS,

FOUNTAIN VALLEY AUTHORITY,

SOUTHEASTERN COLORADO WATER CONSERVANCY DISTRICT,

PUEBLO WEST METROPOLITAN DISTRICT,

ST. CHARLES MESA WATER DISTRICT,

and the BUREAU OF RECLAMATION

Denver, Colorado

1994
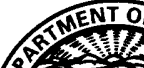


\title{
U.S. DEPARTMENT OF THE INTERIOR \\ BRUCE BABBITT, Secretary
}

\author{
U.S. GEOLOGICAL SURVEY \\ Gordon P. Eaton, Director
}

The use of trade, product, industry, or firm names is for descriptive purposes only and does not imply endorsement by the U.S. Government.

For additional information write to:

Copies of this report can be purchased from:

District Chief

U.S. Geological Survey

Box 25046, MS 415

Denver Federal Center

Denver, CO 80225
U.S. Geological Survey Earth Science Information Center Open-File Reports Section

Box 25286, MS 517

Denver Federal Center

Denver, CO 80225 


\section{CONTENTS}

Abstract
Introduction
Purpose and scope
Description of Pueblo Reservoir and reservoir operations
Water quality of the upper Arkansas River Basin
Methods of investigation
Pcknowledgments.

\section{PLATE}

[In pocket]

1. Map showing location of water-quality sampling sites on Pueblo Reservoir 


\section{FIGURES}

1. Map showing location of Pueblo Reservoir in relation to the upper Arkansas River Basin and location of sampling sites on Pueblo Reservoir...

2-7. Graphs showing:

2. End-of-month contents of Pueblo Reservoir, 1974 through 1989.

3. Monthly mean inflow and outflow for Pueblo Reservoir, 1985 through 1989

4. Monthly temperature profiles for Pueblo Reservoir and initial routing of inflow in Pueblo Reservoir, December 1986 and March through October 1987.

5. Monthly specific-conductance profiles for Pueblo Reservoir, December 1986 and March through

October 1987

6. Relation of residence time, outflow, and reservoir storage in Pueblo Reservoir

7. Minimum reservoir residence times using mean daily inflow and outflow specific conductance, 1986 and 1987

8. Boxplots of measurements of Secchi-disk depths and approximate depths of euphotic zone for Pueblo Reservoir, 1985 through 1989

9. Graphs showing monthly turbidity-measurement profiles of Pueblo Reservoir, December 1986 and March through October 1987.

10. Graphs showing selected monthly dissolved-oxygen concentration and $\mathrm{pH}$-measurement profiles of Pueblo Reservoir, March, June, August, and October 1987

11. Boxplot showing dissolved-inorganic nitrogen concentrations in Pueblo Reservoir near the reservoir surface and near the reservoir bottom, 1986 through 1989

2. Boxplot showing total phosphorus concentrations in Pueblo Reservoir near the reservoir surface and near the reservoir bottom, 1986 through 1989

13. Boxplot showing dissolved-orthophosphorus concentrations in Pueblo Reservoir near the reservoir surface and near the reservoir bottom, 1987 and 1989

14. Graphs showing spatial and temporal variations in concentrations of total-recoverable iron, manganese, and zinc in Pueblo Reservoir, December 1986 and June 1987

15-21. Boxplots showing:

15. Total-organic-carbon concentrations in Pueblo Reservoir near the reservoir surface and near the reservoir bottom, 1985 through 1987

16. Chlorophyll $a$ concentrations in Pueblo Reservoir near the reservoir surface, 1985 through $1987 \ldots \ldots \ldots \ldots . . .51$

17. Phytoplankton density and biovolume in Pueblo Reservoir, 1985 through 1987 ..................................... 53

18. Major phytoplankton group densities and biovolumes in Pueblo Reservoir, winter 1986 .......................... 54

19. Major phytoplankton group densities and biovolumes in Pueblo Reservoir, spring 1986 and 1987........... 58

20. Major phytoplankton group densities and biovolumes in Pueblo Reservoir, summer 1985 through 1987 ... 59

21. Major phytoplankton group densities and biovolumes in Pueblo Reservoir, fall 1985 through 1987........... 61

\section{TABLES}

1. Statistical summary of water-quality data for station 07097000 , Arkansas River at Portland, 1986 through 1989

2. Statistical summary of dissolved-solids and major-ion concentrations in Pueblo Reservoir, 1986 through 1989

3. Relations of dissolved-solids and major-ion concentrations to specific conductance in Pueblo Reservoir...

4. Results of Mann-Whitney test of seasonal differences between dissolved-solids concentrations in Pueblo Reservoir, 1986 through 1989.

5. Estimated loads of total nitrogen and total phosphorus in Pueblo Reservoir inflow and outflow, 1986 and 1987

6. Concentrations of biologically available nitrogen and phosphorus and N:P values for Pueblo Reservoir, 1987 and 1989

7. Statistical summary of total-recoverable and dissolved trace-element concentrations in Pueblo Reservoir, 1986 through 1989

8. A comparison of seasonal and spatial differences in trace-element concentrations in Pueblo Reservoir, 1986 through 1989 
9. Geochemical baselines for selected trace elements in soils in the Western United States and a statistical summary of trace-element concentrations in bottom-sediment samples collected from Pueblo Reservoir at transects 2 through 7 , October 1987

10. Statistical summary of radiochemical concentrations in Pueblo Reservoir, 1985 through $1987 .$.

11. Occurrence and summary of abundant and dominant phytoplankton in Pueblo Reservoir, 1985 through $1987 \ldots . .55$

12. Occurrence of phytoplankton in Pueblo Reservoir that exceed the critical taste-and-odor threshold concentrations, $1985-89$

\section{CONVERSION FACTORS}

$\begin{array}{lll}\text { Multiply } & \text { By } & \text { To obtain }\end{array}$

$\begin{array}{rcl}\text { acre-foot (acre-ft) } & 1,233 & \text { cubic meter } \\ \text { centimeter }(\mathrm{cm}) & 0.3937 & \text { inch } \\ \text { cubic foot per second }\left(\mathrm{ft}^{3} / \mathrm{s}\right) & 0.028317 & \text { cubic meter per second } \\ \text { foot }(\mathrm{ft}) & 0.3048 & \text { meter } \\ \text { inch }(\mathrm{in} .) & 2.540 & \text { centimeter } \\ \text { meter }(\mathrm{m}) & 3.281 & \text { foot } \\ \text { mile }(\mathrm{mi}) & 1.609 & \text { kilometer } \\ \text { pound (lb) } & 0.4536 & \text { kilogram } \\ \text { square mile }\left(\mathrm{mi}^{2}\right) & 2.590 & \text { square kilometer } \\ \text { ton } & 0.9072 & \text { metric ton }\end{array}$

Degree Celsius $\left({ }^{\circ} \mathrm{C}\right)$ may be converted to degree Fahrenheit $\left({ }^{\circ} \mathrm{F}\right)$ by using the following equation:

$$
{ }^{\circ} \mathrm{F}=9 / 5\left({ }^{\circ} \mathrm{C}\right)+32 \text {. }
$$

The following terms and abbreviations also are used in this report:

cell per milliliter (cell/mL)

cubic micrometer $\left(\mu \mathrm{m}^{3}\right)$

cubic micrometer per milliliter $\left(\mu \mathrm{m}^{3} / \mathrm{mL}\right)$

liter (L)

milligram per liter $(\mathrm{mg} / \mathrm{L})$

milligram per square meter per day $\left(\mathrm{mg} / \mathrm{m}^{2} /\right.$ day $)$

microsiemens per centimeter at 25 degrees Celsius $(\mu \mathrm{S} / \mathrm{cm})$

microgram per square meter per day $\left(\mu \mathrm{g} / \mathrm{m}^{2} /\right.$ day $)$

microgram per gram $(\mu \mathrm{g} / \mathrm{g})$

microgram per liter $(\mu \mathrm{g} / \mathrm{L})$

micrometer $(\mu \mathrm{m})$

millirem per year (mrem/yr)

nephelometric turbidity units (NTU)

picocurie per liter (pCi/L) 


\title{
Physical, Chemical, and Biological Characteristics of Pueblo Reservoir, Colorado, 1985-89
}

\author{
ByMichael E. Lewis and Patrick Edelmann
}

\section{Abstract}

Physical, chemical, and biological characteristics of Pueblo Reservoir are described on the basis of data collected from spring 1985 through fall 1989. Also included are discussions of water quality of the upper Arkansas River Basin and the reservoir as they relate to reservoir operations. Pueblo Reservoir is a multipurpose, main-stem reservoir on the Arkansas River about 6 miles west of Pueblo, Colorado. At the top of its conservation pool, the reservoir is more than 9 miles long and ranges in depth from a few feet at the inflow to about 155 feet at the dam. Pueblo Reservoir derives most of its contents from the Arkansas River, which comprises native and transmountain flow.

With respect to water temperature, the reservoir typically was well mixed to weakly stratified during the early spring and gradually became strongly stratified by May. The strong thermal stratification and underflow of the Arkansas River generally persisted into August, at which time the reservoir surface began to cool and the reservoir subsequently underwent fall turnover. Following fall turnover, the reservoir was stratified to some degree in the shallow upstream part and well mixed in the deeper middle and downstream parts. Reservoir residence times were affected by the extent of stratification present. When the reservoir was well mixed, residence times were as long as several months. During the summer when the reservoir was strongly stratified, reservoir releases were large, and when underflow was the prevalent flow pattern of the Arkansas River, reservoir residence times were as short as 30 days.

Most particulate matter settled from the water column between the inflow and a distance of about 5 miles downstream. On occasions of large streamflows and sediment loads from the Arkansas River, particulate matter was transported com- pletely through the reservoir. Water transparency, as measured with a Secchi disk, increased in a downstream direction from the reservoir inflow. The increase probably was a result of sediment settling from the water column in the upstream part of the reservoir. Secchi-disk depths in December through April were larger than those in May through November. Secchi-disk depths were small between May through August as inflow sediment loads and reservoir biomass increased. In the fall, Secchi-disk depths remained small possibly as the result of resuspension of sediment and detritus within the water column.

Dissolved-oxygen concentrations generally were near supersaturation near the reservoir surface. Dissolved-oxygen concentrations decreased with increasing depth. On several occasions during the summer, dissolved oxygen became completely depleted in the hypolimnion of the downstream part of the reservoir. The most extensive period of anoxia that was measured was in August 1988; the bottom 12 to 30 feet of the downstream end of the reservoir was anoxic. Fall turnover typically resulted in well-oxygenated conditions throughout the water column from September or October through the spring. Values of $\mathrm{pH}$ ranged from 7.5 to 9.0 and typically were largest near the surface and decreased with depth.

Dissolved-solids concentrations in the reservoir primarily are affected by dissolved solids in the inflow from the Arkansas River. Concentrations are largest during periods of decreased streamflows, September through April, and decrease with increasing streamflows in May through August. The median dissolved-solids concentration increased from 224 milligrams per liter at the inflow to 262 milligrams per liter at the outflow. However, a statistical analysis of dissolved solids indicated the apparent increase in dissolved-solids concentrations between the inflow and outflow was not significant. Calcium, 
sulfate, and bicarbonate are the major dissolved ions in Pueblo Reservoir.

Concentrations of the major nutrients, nitrogen and phosphorus, varied within the reservoir because of settling of particulate matter, uptake by phytoplankton near the reservoir surface, and releases from the reservoir bottom sediments. Phosphorus was indicated to be a potentially growth-limiting nutrient in the reservoir because of its relatively small concentrations. During 1986 and 1987, the reservoir retained about 35 percent ( 359 tons) of the total nitrogen load and about 83 percent (203 tons) of the total phosphorus load. Settling of particulate matter from the water column and uptake by phytoplankton are the major nutrient sinks in the reservoir.

Barium, iron, manganese, and zinc were the major trace elements in Pueblo Reservoir. Traceelement concentrations in the reservoir varied because of seasonality of trace-element concentrations in the Arkansas River, settling of particulate matter, and flux of trace elements from the bottom sediments. The aquatic-life standard in Pueblo Reservoir for total-recoverable iron (1,000 micrograms per liter) and the public water-supply standard for dissolved manganese (50 micrograms per liter) were exceeded on several occasions during the summer. Elevated concentrations of totalrecoverable iron and dissolved manganese in the Arkansas River during summer runoff contributed to exceedances in the upper part of the reservoir. Flux of manganese from the reservoir bottom sediments during periods of low or depleted dissolved-oxygen concentrations contributed to exceedances in the deeper, downstream parts of the reservoir. Concentrations of lead, mercury, and zinc were elevated in the reservoir bottom sediments and may be the result of metal-mine drainage in the upper Arkansas River Basin.

Median concentrations of total organic carbon ranged from 3.1 to 4.5 milligrams per liter in May through September and from 2.5 to 3.5 milligrams per liter in October through April. Totalorganic-carbon concentrations in the reservoir were largest in the summer when streamflows and total-organic-carbon concentrations are largest in the Arkansas River. Total-organic-carbon concentrations in the reservoir decrease downstream from the reservoir inflow because of settling of particulate organic carbon.
Levels of gross-alpha and gross-beta radioactivity generally were relatively low. In 7 of 31 samples collected, dissolved gross-alpha radioactivity, as natural uranium, exceeded 5 picocuries per liter, the level at which additional radiochemical analyses are recommended for drinking-water supplies. Potential sources of uranium in Pueblo Reservoir include weathering of exposed uranium ore deposits in the upper Arkansas River Basin and a uranium milling operation near Canon City.

Phytoplankton densities and biovolumes measured during the winter, spring, and fall generally were indicative of a small to moderate algal biomass. Phytoplankton production tended to be largest during the summer. During the summer, phytoplankton densities and biovolumes generally were indicative of a moderate to large algal biomass. However, excessive algal production and biomass periodically occurred during the spring, summer, and fall. Three species of phytoplankton that are specifically associated with taste-and-odor problems in drinking water were identified on several occasions in water samples collected from Pueblo Reservoir.

Reservoir operations and hydrodynamics can substantially affect processes that affect reservoir water quality. Stratification, underflow, and hypolimnetic withdrawals affect concentrations of dissolved solids, availability of nutrients, and concentrations of metals in the reservoir. Stratification impedes the mixing of epilimnetic and hypolimnetic waters, and the prevalent underflow that occurs during the summer results in a decrease in the potential dilution of inflowing river water with reservoir water. The underflow also decreases the maximum available nutrient load to the euphotic zone, which can, in turn, offset the maximum algal growth potential. Increased dissolved-solids, nutrient, and metal concentrations that occur in the hypolimnion during the summer are partially offset by hypolimnetic withdrawals.

\section{INTRODUCTION}

Pueblo Reservoir is located about 6 mi upstream from and west of the city of Pueblo, Colo. (fig. 1). The reservoir is an invaluable resource to southeastern Colorado providing: (1) The sole source of municipal and industrial water to the cities of Pueblo and Pueblo West; (2) the primary water supply via the Bessemer 
Ditch to St. Charles Mesa located east of Pueblo; and (3) a supplemental water supply via the Fountain Valley Pipeline for Colorado Springs, Stratmoor Hills, Security, Widefield, and Fountain, which are located several miles north of Pueblo. Altogether, Pueblo Reservoir provides water to about a half million people in southeastern Colorado. In addition, Pueblo Reservoir is one of Colorado's major recreational reservoirs that is used extensively for boating, fishing, and primary contact sports such as swimming, water skiing, and wind surfing. The reservoir provides water to a warmwater, cool-water, and cold-water fish hatchery that is located immediately downstream from the dam. Many of the current and future uses of this multipurpose reservoir depend on maintaining acceptable water quality.

Pueblo Reservoir is the farthest upstream, mainstem reservoir on the Arkansas River and has a drainage area of $4,669 \mathrm{mi}^{2}$. The surface-water quality in the upper Arkansas River Basin is affected by snowmelt runoff (the principal source of annual streamflow), rainfall runoff, mine drainage, effluents from numerous small-capacity wastewater-treatment plants, groundwater inflow, and land and water use in the basin.

Concerns over potential water-quality problems that could result from runoff, mine drainage, discharges of wastewater, salt loadings from return flows, and taste-and-odor problems associated with nuisance algae led to a comprehensive water-quality investigation of Pueblo Reservoir. The study was begun in the spring of 1985 by the U.S. Geological Survey in cooperation with the Pueblo Board of Water Works, Fountain Valley Authority, Southeastern Colorado Water Conservancy District, Pueblo West Metropolitan District, St. Charles Mesa Water District, and the Bureau of Reclamation.

This report is the third report prepared as part of the study. The first report (Edelmann, 1988) describes the water quality of the upper Arkansas River Basin and the quality of water entering the reservoir and some of the areal, vertical, and seasonal water-quality variations that occurred in Pueblo Reservoir during 1985. Some general information about potential contaminants to Pueblo Reservoir also is provided in the first report. The second report (Edelmann and others, 1991) contains water-quality data collected during 1985 through 1987.

\section{Purpose and Scope}

This report describes the temporal and spatial variations of physical, chemical, and biological characteristics of Pueblo Reservoir and provides a discussion of water quality of the upper Arkansas River Basin and the reservoir as they relate to reservoir operations. Descriptions of the following physical, chemical, and biological characteristics of Pueblo Reservoir are included in this report: measurements of water temperature, specific conductance, water transparency and turbidity, dissolved oxygen, and $\mathrm{pH}$; and analyses of dissolved solids, major nutrients, trace elements, organic carbon, radiochemical constituents, chlorophyll $a$, density and relative abundance of phytoplankton, and phytoplankton biomass. These constituents were analyzed to provide a thorough description of water-quality conditions in the reservoir and baseline of information that can be used for future investigations. Data were collected from the spring of 1985 through the fall of 1989 and are published in Ugland and others $(1988,1990)$ and Edelmann and others (1991).

\section{Description of Pueblo Reservoir and Reservoir Operations}

Pueblo Reservoir is a multipurpose storage facility of the Fryingpan-Arkansas Project that was authorized by Public Law 87-590. Storage began in January 1974, and the concrete and earth-fill dam built on the Arkansas River was completed in August 1975. The reservoir has a total initial storage capacity of 357,678 acre-ft. Since water was first impounded in Pueblo Reservoir, reservoir storage has varied greatly because of variations in annual inflow and demand for the stored water (fig. 2). Prior to 1983, the reservoir contents ranged from 22,680 acre-ft in November 1974 to 111,920 acre-ft in March 1982. From early 1983 to June 1988, the reservoir contents were more than 200,000 acre- $\mathrm{ft}$ because of greater-than-normal streamflows from the Arkansas River. From 1985 to 1987, reservoir contents ranged from 295,480 acre-ft in February 1985 to 228,850 acre-ft in October 1987 (fig. 2). During 1988 and 1989, reservoir contents decreased because of smaller streamflow in the Arkansas River upstream from the reservoir and large downstream demands for stored water. Reservoir contents decreased to 110,770 acre-ft in October 1989 (U.S. Bureau of Reclamation, written commun., 1990).

At all pool elevations, the reservoir is dendritic, and the shoreline is irregular. At minimum pool (30,355 acre-ft), the reservoir is about $3.5 \mathrm{mi}$ long, ranges in width from a few hundred feet to about $1.3 \mathrm{mi}$, and ranges in depth from a few feet at the inflow to about $72 \mathrm{ft}$ at the dam. At the top of the conservation pool (about 265,000 acre-ft or an elevation of about $4,880 \mathrm{ft}$ ), the reservoir is more than $9 \mathrm{mi}$ long, ranges in width from about 0.3 to about $2.2 \mathrm{mi}$, and has a depth 


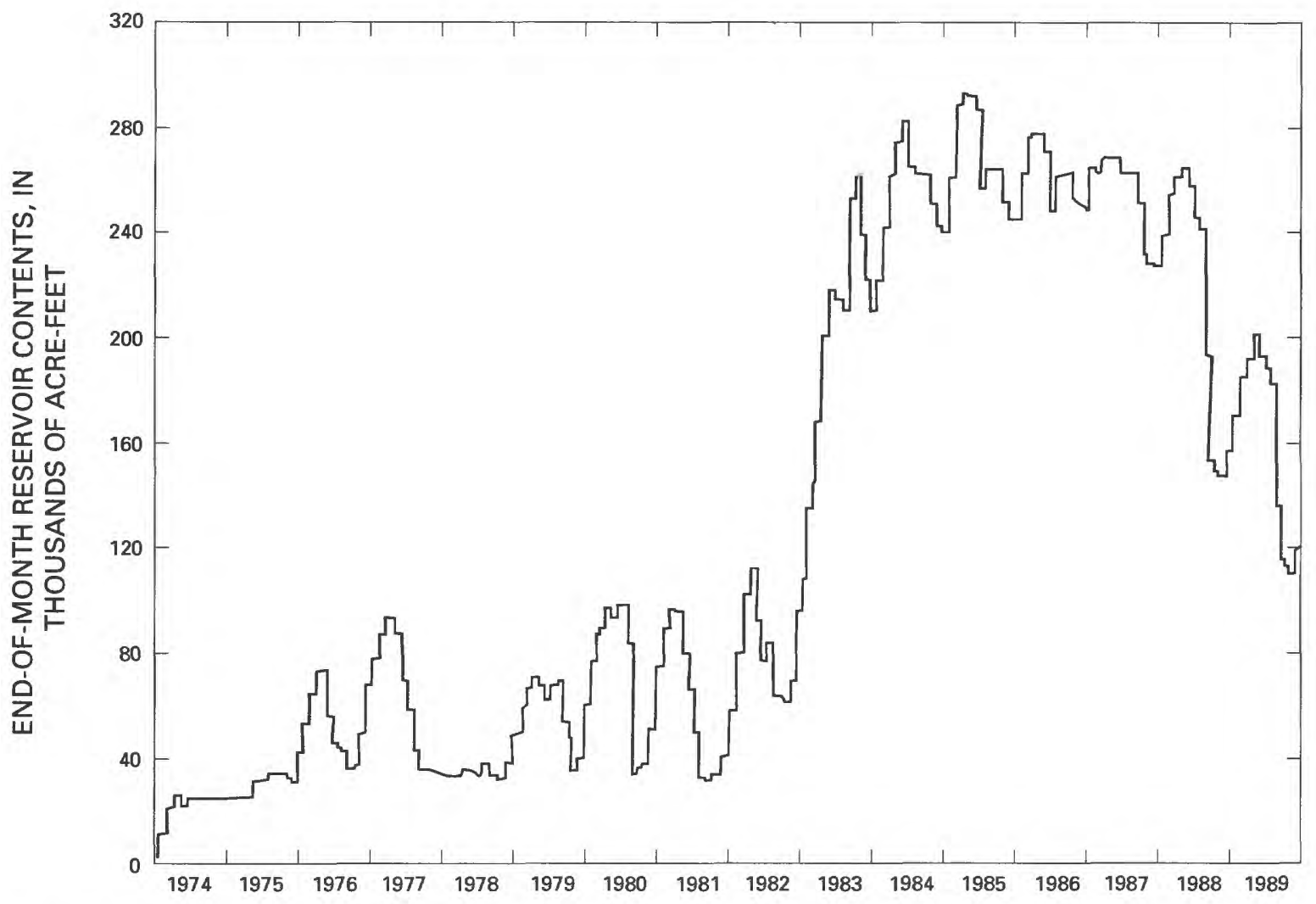

Figure 2. End-of-month contents of Pueblo Reservoir, 1974 through 1989.

that ranges from a few feet at the inflow to about $155 \mathrm{ft}$ at the dam (U.S. Bureau of Reclamation, 1972).

Pueblo Reservoir derives almost all of its contents from streamflow in the Arkansas River, which is comprised of native and transmountain flow. From 1985 through 1989, an average of 53 percent of the annual inflow to Pueblo Reservoir entered during May through July (U.S. Bureau of Reclamation, written commun., 1990).

Water is released from the reservoir through the river outlets, the Bessemer Ditch outlet, the south outlets, and the fish hatchery outlets. Outlet works also have been constructed for future developments downstream from the dam, such as a municipal outlet for a future water-treatment plant for the city of Pueblo. The river outlets are at an elevation of $4,766 \mathrm{ft}$ or about $41 \mathrm{ft}$ above the reservoir bottom and release the majority of the water from the reservoir. Water released through the river outlets provides municipal and industrial water to Pueblo and irrigation water to downstream irrigators. The Bessemer Ditch outlet is located at an elevation of $4,780 \mathrm{ft}$ or about $55 \mathrm{ft}$ above the reservoir bottom and releases water to the Bessemer Ditch, an irrigation canal, that provides water to
St. Charles Mesa. The south outlets transport water to Pueblo West and the Fountain Valley Pipeline, which is a 45-mi-long pipeline that transports water to the city of Colorado Springs and the communities of Stratmoor Hills, Security, Widefield, and Fountain (fig. 1). The south outlets release water through multilevel intake lines located at elevations of $4,840,4,805,4,776$, and $4,768 \mathrm{ft}$, which correspond to about $115,80,51$, and $43 \mathrm{ft}$, respectively, above the reservoir bottom. Water can be released concurrently from one or more of these intake lines. The fish hatchery outlets also are comprised of multilevel intake lines and can release water from elevations of 4,851, 4,811, 4,786, and 4,736 ft, which correspond to about $126,86,61$, and $11 \mathrm{ft}$ above the reservoir bottom (U.S. Bureau of Reclamation, written commun., 1986).

From 1985 through 1989, 88.2 percent of the total outflow was released through the river outlets, 11.3 percent was released through the Bessemer Ditch outlet, and 0.5 percent was released through the south outlets to the Fountain Valley Pipeline (fig. 3). Water is released through the river and south outlets during the entire year. However, water has been released through the south outlets only since the Fountain Valley 

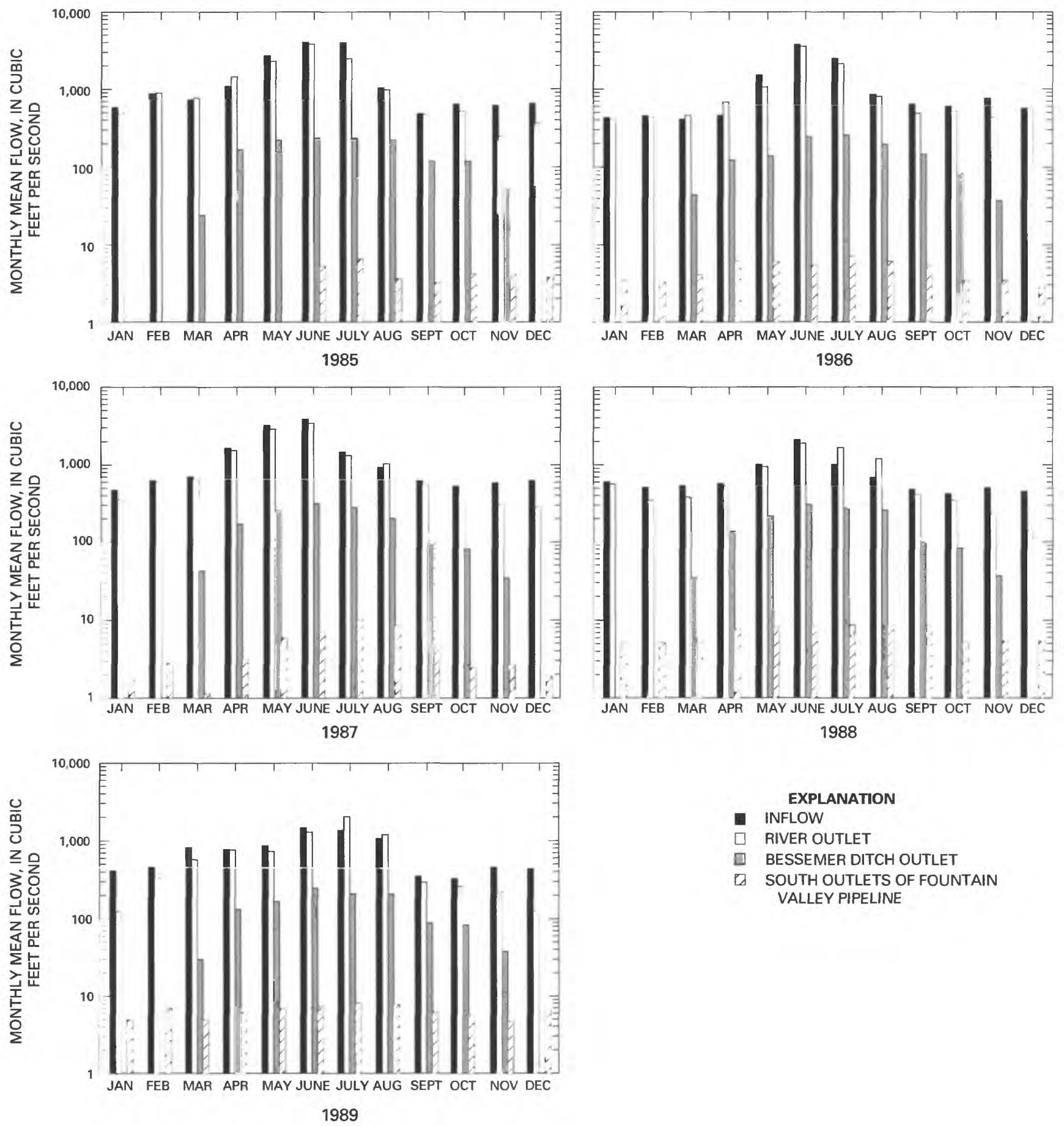

Figure 3. Monthly mean inflow and outflow for Pueblo Reservoir, 1985 through 1989. 
Pipeline project was completed in June 1985. Water is released through the Bessemer Ditch outlet during the spring, summer, and fall. During the winter, St. Charles Mesa obtains its surface water by diverting Arkansas River water downstream from the dam.

In general, at least since 1985 , a volume of water comparable to the amount of annual inflow has been released annually from the reservoir outlet works. However, a net increase in storage occurs from November to April of each year because of the Winter Water Storage Program. Because of Pueblo Reservoir operation practices, the reservoir has a short residence time. From 1985 through 1989, an average of 12 percent of the reservoir contents was released each month during November to April (the period of the Winter Water Storage Program); an average of 52 percent of the reservoir contents was released each month during May and June (the major snowmelt-runoff period); an average of 47 percent of the reservoir contents was released each month during July and August (the upper-basin reservoir-release period and rainfall-runoff period); and an average of 15 percent of the reservoir contents was released each month during September and October.

\section{Water Quality of the Upper Arkansas River Basin}

A discussion of the physical and chemical conditions of the Arkansas River upstream from Pueblo Reservoir is necessary to fully understand the physical and chemical characteristics of the reservoir, because the Arkansas River has a dominant effect on the reservoir. The chemical quality of the upper Arkansas River Basin has been studied by the Federal Water Pollution Control Administration (1968), Moran and Wentz (1974), Wentz (1974), La Bounty and others (1975), Miles (1977), Roline and Boehmke (1981), Crouch and others (1984), Cain (1987), and Kimball and others (1988). The reader is referred to these reports for a detailed description of the historical water quality in the upper Arkansas River Basin. The following discussion is intended to provide an overview of the quality of water in the upper basin and to provide a description of the quality of water entering the reservoir.

The chemical quality of surface water in the Arkansas River Basin is affected by runoff from snowmelt and rainfall, transmountain diversions, mine drainage, wastewater-treatment-plant effluents, ground water, and land and water use within the basin. Water entering the basin near the headwaters of the Arkansas River and its tributaries is derived mostly from snow- melt and generally is suitable for most uses (Federal Water Pollution Control Administration, 1968).

Dissolved-solids concentrations in the upper reaches of the Arkansas River have been increased by acid mine drainage in the basin headwaters (Cain, 1987). Dilution by tributary inflows results in decreasing dissolved-solids concentrations and specific conductance between Leadville and Buena Vista. Dissolved solids and specific conductance increase downstream from Buena Vista because of: (1) dissolution of sedimentary rock minerals, (2) irrigation return flows and saline ground-water inflow, and (3) discharges from wastewater-treatment plants. Dissolved solids and specific conductance increased only slightly between Buena Vista and Canon City (fig. 1), but dissolved solids increase substantially and specific conductance almost doubles in the 20-mi reach downstream from Canon City, primarily as a result of saline ground-water inflows and irrigation return flows (Cain, 1987).

The limited amount of nutrient data available for the upper Arkansas River Basin indicates that nitrogen and phosphorus concentrations increase downstream (Edelmann and others, 1991). Concentrations of total nitrogen generally are less than $1 \mathrm{mg} / \mathrm{L}$, and totalphosphorus concentrations generally are less than $0.2 \mathrm{mg} / \mathrm{L}$.

Acid mine drainage has resulted in relatively large concentrations of cadmium, iron, lead, manganese, nickel, and zinc in the upper Arkansas River and is a major source of these constituents to Pueblo Reservoir (A.J. Medine, Water Science, Boulder, Colorado, written commun., 1991). Weathering of sedimentary rocks in the lower half of the basin seems to be another major source of iron and manganese to the river and reservoir. Chemical precipitation; sorption to iron and aluminum oxides, organics, and clay minerals; sedimentation; and dilution contribute to downstream decreases in most dissolved-metal concentrations in the upper Arkansas River.

The chemical quality of water entering Pueblo Reservoir can be summarized by using data collected at station 07097000, Arkansas River at Portland (table 1). The U.S. Geological Survey has been analyzing waterquality samples collected at this station since 1977 . Daily measurements of water temperature and specific conductance have been made since 1979. A summary and discussion of water-quality data collected at this station from 1977 through 1985 are provided in Edelmann (1988).

Strong seasonal variations in water temperature, specific conductance, and dissolved-solids concentrations occur in the Arkansas River. Mean daily water temperature of the Arkansas River at Portland ranged 
Table 1. Statistical summary of water-quality data for station 07097000, Arkansas River at Portland, 1986 through 1989

$\left[\mathrm{ft}^{3} / \mathrm{s}\right.$, cubic feet per second; ${ }^{\circ} \mathrm{C}$, degrees Celsius; $\mu \mathrm{S} / \mathrm{cm}$, microsiemens per centimeter at 25 degrees Celsius; mg $/ \mathrm{L}$, milligrams per liter; NTU, nephelometric turbidity units; $\mu \mathrm{g} /$, micrograms per liter; <, less than; NA, statistic not applicable]

\begin{tabular}{|c|c|c|c|c|c|c|c|}
\hline Constituent & $\begin{array}{l}\text { Number } \\
\text { of } \\
\text { measure- } \\
\text { ments or } \\
\text { analyses }\end{array}$ & $\begin{array}{c}\text { Number } \\
\text { of } \\
\text { measure- } \\
\text { ments } \\
\text { less than } \\
\text { detectlon } \\
\text { level' }\end{array}$ & Mean & $\begin{array}{l}\text { Standard } \\
\text { deviation }\end{array}$ & $\begin{array}{l}\text { Twenty- } \\
\text { fifth } \\
\text { percentlie }\end{array}$ & Median & $\begin{array}{l}\text { Seventy- } \\
\text { fifth } \\
\text { percentile }\end{array}$ \\
\hline Streamflow, instantaneous $\left(\mathrm{ft}^{3} / \mathrm{s}\right)$ & 130 & 0 & 1,228 & 874 & 608 & 1,120 & 1,525 \\
\hline Temperature $\left({ }^{\circ} \mathrm{C}\right)$ & 135 & 0 & 16.1 & 5.6 & 13.9 & 17.0 & 21.0 \\
\hline Specific conductance $(\mu \mathrm{S} / \mathrm{cm})$ & 89 & 0 & 363 & 133 & 230 & 369 & 493 \\
\hline Oxygen, dissolved (mg/L) & 122 & 0 & 9.4 & 2.1 & 7.9 & 8.6 & 11.0 \\
\hline pH (standard units) & 129 & 0 & NA & NA & 8.1 & 8.4 & 8.8 \\
\hline Turbidity (NTU) & 80 & 0 & 42 & 126 & 4.2 & 7.1 & 27 \\
\hline Nitrogen, total (mg/L) & 19 & 0 & .97 & 2.4 & .23 & .37 & .62 \\
\hline $\begin{array}{l}\text { Nitrite plus nitrate as nitrogen, } \\
\text { dissolved }(\mathrm{mg} / \mathrm{L})\end{array}$ & 35 & 7 & .22 & .19 & .10 & .16 & .33 \\
\hline $\begin{array}{l}\text { Nitrite plus nitrate as nitrogen, } \\
\text { total (mg/L) }\end{array}$ & 19 & 0 & .22 & .14 & .11 & .18 & .30 \\
\hline $\begin{array}{l}\text { Ammonia as nitrogen, dissolved } \\
(\mathrm{mg} / \mathrm{L})\end{array}$ & 35 & 10 & .03 & .03 & .01 & .03 & .04 \\
\hline Ammonia as nitrogen, total $(\mathrm{mg} / \mathrm{L})$ & 44 & 9 & .04 & .04 & .02 & .03 & .04 \\
\hline $\begin{array}{l}\text { Ammonia plus organic nitrogen as } \\
\text { nitrogen, dissolved (mg/L) }\end{array}$ & 44 & 2 & .61 & 1.5 & .20 & .30 & .50 \\
\hline $\begin{array}{l}\text { Phosphorus, orthophosphate, as } \\
\text { phosphorus, dissolved (mg/L) }\end{array}$ & 33 & 1 & 0.03 & 0.02 & 0.02 & 0.03 & 0.05 \\
\hline Phosphorus, dissolved (mg/L) & 34 & 0 & .05 & .02 & .03 & .04 & .06 \\
\hline Phosphorus, total (mg/L) & 41 & 0 & .14 & .15 & .06 & .08 & .14 \\
\hline Hardness (mg/L) & 42 & 0 & 174 & 53 & 135 & 190 & 213 \\
\hline Calcium, dissolved (mg/L) & 42 & 0 & 47 & 13 & 38 & 51 & 57 \\
\hline Magnesium, dissolved (mg/L) & 42 & 0 & 13.7 & 5.1 & 9.7 & 15.5 & 18.0 \\
\hline Potassium, dissolved (mg/L) & 42 & 0 & 2.3 & .69 & 1.8 & 2.5 & 2.7 \\
\hline Sodium, dissolved (mg/L) & 42 & 0 & 19.7 & 8.1 & 14.8 & 22.7 & 26.0 \\
\hline Chloride, dissolved (mg/L) & 41 & $\mathbf{0}$ & 7.6 & 3.0 & 5.0 & 8.3 & 10.0 \\
\hline Fluoride, dissolved (mg/L) & 41 & $\mathbf{0}$ & .50 & .13 & .42 & .5 & .6 \\
\hline Sulfate, dissolved (mg/L) & 55 & 0 & 82 & 31 & 60 & 86 & 110 \\
\hline Alkalinity, laboratory (mg/L) & 15 & $\mathbf{0}$ & 128 & 28 & 113 & 132 & 154 \\
\hline $\begin{array}{l}\text { Carbonate, as calcium carbonate } \\
(\mathrm{mg} / \mathrm{L})\end{array}$ & 8 & 0 & 2.4 & 3.0 & 0 & 1 & 4.8 \\
\hline $\begin{array}{l}\text { Bicarbonate, as calcium carbonate } \\
(\mathrm{mg} / \mathrm{L})\end{array}$ & 8 & $\mathbf{0}$ & 142 & 43 & 102 & 143 & 183 \\
\hline Dissolved solids at $180^{\circ} \mathrm{C}(\mathrm{mg} / \mathrm{L})$ & 23 & 0 & 277 & 83 & 200 & 306 & 335 \\
\hline
\end{tabular}


Table 1. Statistical summary of water-quality data for station 07097000, Arkansas River at Portland, 1986 through 1989 --Continued

\begin{tabular}{|c|c|c|c|c|c|c|c|}
\hline Constituent & $\begin{array}{c}\text { Number } \\
\text { of } \\
\text { measure- } \\
\text { ments or } \\
\text { anaiyses }\end{array}$ & $\begin{array}{c}\text { Number } \\
\text { of } \\
\text { measure- } \\
\text { ments } \\
\text { less than } \\
\text { detection } \\
\text { level' }\end{array}$ & Mean & $\begin{array}{l}\text { Standard } \\
\text { deviation }\end{array}$ & $\begin{array}{l}\text { Twenty- } \\
\text { fifth } \\
\text { percentile }\end{array}$ & Median & $\begin{array}{l}\text { Seventy- } \\
\text { fifth } \\
\text { percentile }\end{array}$ \\
\hline $\begin{array}{l}\text { Dissolved solids, sum of } \\
\text { constituents }(\mathrm{mg} / \mathrm{L})\end{array}$ & 41 & 0 & 258 & 84 & 190 & 285 & 327 \\
\hline Arsenic, dissolved $(\mu \mathrm{g} / \mathrm{L})$ & 33 & 27 & .53 & 1.4 & .04 & .14 & .44 \\
\hline Arsenic, total $(\mu \mathrm{g} / \mathrm{L})$ & 18 & 12 & 1.2 & 1.7 & .28 & .63 & 2 \\
\hline Barium, dissolved $(\mu \mathrm{g} / \mathrm{L})$ & 34 & 0 & 56 & 17 & 39 & 60 & 67 \\
\hline Barium, total recoverable $(\mu \mathrm{g} / \mathrm{L})$ & 19 & 0 & 139 & 88 & 78 & 106 & 182 \\
\hline Cadmium, dissolved $(\mu \mathrm{g} / \mathrm{L})$ & 32 & 22 & .99 & 1.2 & .30 & .60 & 1.0 \\
\hline Cadmium, total recoverable $(\mu \mathrm{g} / \mathrm{L})$ & 19 & 19 & NA & NA & $<10$ & $<10$ & $<10$ \\
\hline Chromium, dissolved $(\mu \mathrm{g} / \mathrm{L})$ & 32 & 19 & 1.1 & .92 & .50 & .83 & 1.8 \\
\hline Chromium, total recoverable $(\mu \mathrm{g} / \mathrm{L})$ & 19 & 0 & 7.5 & 7.8 & 3 & 4 & 10 \\
\hline Cobalt, dissolved $(\mu \mathrm{g} / \mathrm{L})$ & 13 & 13 & NA & NA & $<3$ & $<3$ & $<3$ \\
\hline Copper, dissolved $(\mu \mathrm{g} / \mathrm{L})$ & 34 & 0 & 5.2 & 7 & 2 & 4 & 5 \\
\hline Copper, total recoverable $(\mu \mathrm{g} / \mathrm{L})$ & 18 & 8 & 13.7 & 9.4 & 7.4 & 11 & 20.3 \\
\hline Iron, dissolved $(\mu \mathrm{g} / \mathrm{L})$ & 34 & 0 & 46 & 57 & 22 & 30 & 40 \\
\hline Iron, total recoverable $(\mu \mathrm{g} / \mathrm{L})$ & 19 & 0 & 3,818 & 4,112 & 515 & 2,400 & 6,330 \\
\hline Lead, dissolved $(\mu \mathrm{g} / \mathrm{L})$ & 34 & 25 & 1.2 & 2.9 & .13 & .37 & 1 \\
\hline Lead, total recoverable $(\mu \mathrm{g} / \mathrm{L})$ & 19 & 10 & 14 & 15.3 & 5 & 9.4 & 20 \\
\hline Manganese, dissolved $(\mu g / L)$ & 34 & 0 & 19.7 & 8.2 & 13 & 18.5 & 27 \\
\hline $\begin{array}{l}\text { Manganese, total recoverable } \\
(\mu \mathrm{g} / \mathrm{L})\end{array}$ & 19 & 0 & 189 & 218 & 47 & 95 & 248 \\
\hline Molybdenum, dissolved $(\mu \mathrm{g} / \mathrm{L})$ & 34 & 15 & 6.5 & 3.1 & 4.4 & 5.9 & 8 \\
\hline $\begin{array}{l}\text { Molybdenum, total recoverable } \\
(\mu \mathrm{g} / \mathrm{L})\end{array}$ & 19 & 0 & 8.9 & 3.5 & 5 & 10 & 12 \\
\hline Nickel, dissolved $(\mu \mathrm{g} / \mathrm{L})$ & 34 & 8 & 5.8 & 10.4 & 1.1 & 3.5 & 8.3 \\
\hline Nickel, total recoverable $(\mu \mathrm{g} / \mathrm{L})$ & 19 & 6 & 16.2 & 10.6 & 9 & 15 & 20 \\
\hline Selenium, dissolved $(\mu \mathrm{g} / \mathrm{L})$ & 34 & 9 & 1.5 & .82 & .89 & 1 & 2 \\
\hline Selenium, total recoverable $(\mu \mathrm{g} / \mathrm{L})$ & 19 & 4 & 1.5 & .76 & 1 & 1 & 2 \\
\hline Silver, dissolved $(\mu \mathrm{g} / \mathrm{L})$ & 33 & 29 & NA & NA & $<1$ & $<1$ & $<1$ \\
\hline Silver, total recoverable $(\mu \mathrm{g} / \mathrm{L})$ & 19 & 19 & NA & NA & $<10$ & $<10$ & $<10$ \\
\hline Zinc, dissolved $(\mu \mathrm{g} / \mathrm{L})$ & 34 & 0 & 19.9 & 15.7 & 8.8 & 14 & 30 \\
\hline Zinc, total recoverable $(\mu \mathrm{g} / \mathrm{L})$ & 19 & 0 & 123 & 73 & 64 & 113 & 190 \\
\hline Carbon, organic total (mg/L) & 16 & 0 & 5.7 & 4.3 & 3.0 & 4.0 & 7.7 \\
\hline
\end{tabular}


from about $0^{\circ} \mathrm{C}$ in December through February to about $20^{\circ} \mathrm{C}$ in July and August during 1986 through 1989. Mean daily specific conductance usually is largest from January to March when streamflows are smallest, and the smallest specific-conductance values occur during May through July when streamflows are the largest. During 1986 through 1989, the largest mean daily specific conductance was $793 \mu \mathrm{S} / \mathrm{cm}$, which occurred during February 1989; the smallest mean daily specific conductance of $147 \mu \mathrm{S} / \mathrm{cm}$ occurred in June 1986. Dissolved-solids concentrations vary proportionately with specific conductance. Calcium is the dominant cation and bicarbonate and sulfate are the codominant anions. Cain (1987) determined relations between: (1) specific conductance and streamflow, (2) specific conductance and concentration of dissolved solids, and (3) specific conductance and concentrations of major ions. Hardness values at station 07097000 ranged from $66 \mathrm{mg} / \mathrm{L}$ (moderately hard) to $240 \mathrm{mg} / \mathrm{L}$ (very hard) as calcium carbonate. Hardness varies inversely with streamflow.

Dissolved oxygen, $\mathrm{pH}$, and alkalinity data summarized in table 1 indicate that the water at station 07097000 is: (1) well oxygenated, (2) alkaline ( $\mathrm{pH}$ values usually range from 8.1 to 8.8), and (3) well buffered (median alkalinity equals $132 \mathrm{mg} / \mathrm{L}$ as calcium carbonate).

Concentrations of total nitrogen at station 07097000 generally are less than $1.0 \mathrm{mg} / \mathrm{L}$, and organic nitrogen is the dominant nitrogen species (table 1 ). Edelmann (1988) reported that 61 percent of the total nitrogen consisted of organic nitrogen, 32 percent as nitrite plus nitrate, and 7 percent as ammonia. Additionally, about 70 percent of the total nitrogen was dissolved. Concentrations of total phosphorus ranged from 0.038 to $0.88 \mathrm{mg} / \mathrm{L}$ during 1986 through 1989 ; the median total phosphorus concentration was $0.08 \mathrm{mg} / \mathrm{L}$. Based on the analyses of 34 water samples collected from 1986 through 1989, about 50 percent of the total phosphorus was dissolved.

Concentrations of total and dissolved trace elements analyzed from water samples collected at station 07097000 are summarized in table 1. Trace elements that have the largest concentrations are barium, iron, manganese, and zinc. Most of the samples collected were filtered and analyzed for dissolved concentrations. However, several of the samples were analyzed for concentrations of dissolved and total trace elements. These analyses indicate that most of the trace elements are attached to suspended material; the largest concentrations of trace elements occur with the largest streamflows that transport relatively large quantities of suspended material.

\section{Methods of Investigation}

Following an initial reconnaissance of Pueblo Reservoir in May 1985, a comprehensive water-quality investigation of the reservoir was done in two phases. Phase I was done from the spring of 1985 through the fall of 1987 and included intensive collection of reservoir water-quality data from seven transects located from the inflow (transect 1) to the dam (transect 7) (pl. 1). Water-quality samples were collected from seven transects in the reservoir in order to adequately represent any potential effects by tributaries or reservoir morphometry: Three sampling sites were selected along each transect. Onsite measurements of water temperature, specific conductance, water transparency, dissolved oxygen, and $\mathrm{pH}$ were made at all 21 sites, and water-quality samples were collected from the middle site in each transect. Onsite measurements were made monthly in the summer of 1985 , biweekly in the summer of 1986, and weekly in the summer of 1987. Water-quality samples generally were collected monthly in the spring, summer, and fall. A sample also was collected in the winter when weather conditions permitted.

Phase II was done from the summer of 1988 through the fall of 1989. Analysis of data collected during Phase I indicated that data collected from sites $3 \mathrm{~B}, 5 \mathrm{C}$, and $7 \mathrm{~B}$ adequately describe the spatial variations of the physical, chemical, and biological characteristics within the reservoir. Therefore, waterquality data collection during Phase II and most analysis and discussion of water-quality data for the study are limited to sites 3B, 5C, and 7B. During Phase II, data were collected four times annually: (1) spring, (2) early summer, (3) late summer, and (4) fall. Biological data were collected twice in 1988 and four times in 1989.

Bottom-sediment and interstitial pore-water samples were collected and analyzed as part of a separate, unrelated research effort (Callendar and others, 1988). Bottom-sediment samples were collected from 23 locations in October 1987 and analyzed for major chemical constituents. Additionally, samples of bottom sediments were collected for trace-element and nutrient analyses of the interstitial water in October 1987 from transects 2, 5, and 7 and in August 1988 from transects 3 and 6. In September 1990, bottomsediment samples were collected from transects 4 and 5 for nutrient analyses of the interstitial water.

Water temperature, specific conductance, dissolved oxygen, and $\mathrm{pH}$ generally were measured at $3-\mathrm{ft}$ intervals from the reservoir surface to the reservoir bottom with a multiparameter instrument. Water transparency was measured with a Secchi disk. Water samples 
were collected for chemical analyses from near the reservoir surface and from near the reservoir bottom using a 4-L, nonmetallic, 2-ft-long water-sampling bottle. The near-surface samples were collected at the Secchidisk depth, and the near-bottom sample was collected about $3 \mathrm{ft}$ above the reservoir bottom. The near-surface samples were collected to characterize conditions in the photic zone, and the near-bottom samples were collected to characterize conditions in the hypolimnion. Samples collected for chemical analyses were treated and preserved using methods described in Feltz and others (1985), except samples treated onsite for analyses of nitrogen were not preserved with mercuric chloride. Mercuric chloride was not added to the nitrogen samples analyzed by the Pueblo Board of Water Works Laboratory because of interference effects. The inorganic chemical constituents discussed in this report were analyzed using methods described by Fishman and Friedman (1985). The Pueblo Board of Water Works Laboratory analyzed samples collected for analyses of turbidity, major ions, dissolved and total nitrogen species, and dissolved and total-recoverable trace elements. The U.S. Geological Survey National Water Quality Laboratory in Arvada, Colorado, analyzed samples collected for sulfate, dissolved and total phosphorus species, radiochemical constituents, and total organic carbon. Analyses for radiochemical constituents were made using methods developed by Thatcher and others (1977). Total organic carbon was analyzed using methods described by Wershaw and others (1983). The U.S. Geological Survey National Water Quality Laboratory also analyzed samples for all constituents that were collected for quality-assurance purposes (Edelmann and others, 1991).

Sediment cores were collected for analysis of selected trace elements from reservoir sites using a 4-ft-long, weighted, stainless-steel 4-in. corer that contained a plastic sleeve. The sediment cores were subsampled at the 0-2-cm depth interval and the 4-6-cm depth interval for total-recoverable analyses of selected constituents by the Pueblo Board of Water Works Laboratory and for total analyses by the U.S. Geological Survey, Geologic Division Laboratory in Lakewood, Colorado. In addition, interstitial water was collected at discrete intervals and analyzed by the U.S. Geological Survey.

Biological samples were collected for analyses of phytoplankton and chlorophyll $a$. Biological analyses were done by Chadwick and Associates of Littleton, Colorado. Phytoplankton samples were collected from a single depth near the reservoir surface using a 4-L, nonmetallic, 2-ft-long, water-sampling bottle. Phytoplankton samples were preserved using a 37-percent formaldehyde solution. Phytoplankton density values are reported in cells per milliliter. Chlorophyll $a$ samples were collected from near the reservoir surface and from near the reservoir bottom. The sampling depths were the same as the depths at which water samples were collected for chemical analyses. One to two liters of water were filtered through a $0.45-\mu \mathrm{m}$ filter; the filter then was frozen onsite using dry ice. Chlorophyll $a$ was extracted in the laboratory using acetone. The analyses were made using the chromatography and spectroscopy method (Britton and Greeson, 1989), and a correction was made for pheophytin (Chadwick and Associates, Littleton, Colo., written commun., 1985).

In addition to data collection on Pueblo Reservoir, water samples were routinely collected from the Arkansas River upstream and downstream from the reservoir for analyses of inorganic chemical constituents. Specifically, samples were collected from station 07097000, Arkansas River at Portland (upstream station) and station 07099400, Arkansas River above Pueblo (fig. 1).

\section{Acknowledgments}

The authors would like to express special thanks for the cooperation, interest, and support provided by: Alan C. Hamel, James D. Hurt, and Brian B. Elson, Pueblo Board of Water Works; Jim Phillips, Edward W. Bailey, and Patricia McGlothlin, Fountain Valley Authority; Charles L. Thompson, Southeastern Colorado Water Conservancy District; Eugene M. Zamecki and Richard Hayes, Pueblo West Metropolitan District; Lee W. Simpson, David K. Simpson, and Donald Williams, St. Charles Mesa Water District; and Jack Garner, Bureau of Reclamation. The analytical chemistry work done by Julie A. Scaplo and Don A. Colalancia, Pueblo Board of Water Works, during the study is greatly appreciated.

\section{PHYSICAL CHARACTERISTICS}

The physical characteristics of the reservoir discussed in this section are thermal and specificconductance stratification and mixing patterns, residence times, water transparency, and distribution and transport of particulate matter. These characteristics affect many important chemical and biological processes within the reservoir. 


\section{Thermal Stratification and Mixing Patterns}

Thermal stratification is one of the most important physical processes in the annual cycle of a lake or reservoir. Thermal stratification is a direct result of heating by the sun and the variability of water density with temperature. Typically, reservoirs such as Pueblo Reservoir that are located in the temperate zone undergo an annual cycle of warming and cooling that affect the timing and extent of stratification and mixing. In Pueblo Reservoir, thermal stratification results in a warm, less dense water layer near the reservoir surface-the epilimnion; a cooler, more dense deep layer-the hypolimnion; and a transitional zone between the two layers-the thermocline or metalimnion. The density gradient that results from thermal stratification suppresses the vertical movement of water particles while allowing their horizontal movement to become more pronounced and persistent (Wunderlich, 1971).

Stratification and mixing patterns in Pueblo Reservoir were evaluated with temperature-profile measurements that generally were made at 3-ft-depth increments from the water surface to the reservoir bottom at several established transects located between the reservoir inflow and the dam (fig. 1) from 1985 through 1989 (Ugland and others, 1988, 1990; Edelmann and others, 1991). The temperature-profile data indicate that there is little lateral variation in temperatures within a transect; therefore, the thermal profile of the reservoir may be adequately defined with measurements made at a central location within each transect. Additionally, diel variations in the water-temperature profile were evaluated with temperature data collected during separate 24-hour periods in July 1986, May 1987, and July 1987 (Edelmann and others, 1991). During these periods, reservoir temperature profiles did not vary enough to result in diel variations in reservoir stratification and mixing patterns; therefore, a single temperature profile made during the day generally can be expected to define the daily mixing and stratification patterns.

A comparison of temperature-profile data collected from 1985 through 1989 (Ugland and others, 1988, 1990; Edelmann and others, 1991) indicates there is little year-to-year variation in the spatial and temporal temperature patterns in Pueblo Reservoir. Temperature-profile data were collected for a 5-year period that included a wide range of hydrologic conditions (figs. 2 and 3); therefore, unless Arkansas River or Pueblo Reservoir water-operations practices change substantially, the annual stratification and mixing patterns observed in 1985 through 1989 can be expected to continue in the future if water levels, inflows, and out- flows remain within the range observed during 1985 through 1989.

The temperature profiles (fig. 4) also were used to evaluate the initial routing of the Arkansas River within the reservoir-the inflowing water enters the reservoir at a depth of equal density, which for Pueblo Reservoir generally is determined by water temperature. Inflow that is warmer than the reservoir will enter as overflow at the reservoir surface because the warm inflow is less dense than the colder reservoir water. Interflow, which is the routing of water into the middle of the water column, results when the inflow is cooler and more dense than the surface water and warmer and less dense than the bottom water. Underflow results when the inflow is colder and more dense than the reservoir water and results in initial routing of the inflow along the reservoir bottom. The point in a reservoir where inflow plunges or flows beneath the reservoir surface is referred to as the plunge point.

Underflow and interflow seem to be the more dominant flow patterns in Pueblo Reservoir. The plunge point in the reservoir typically is located in the upstream end of the reservoir between transects 1 and 3 . Routing of inflow through the entire reservoir cannot be determined by the temperature of the inflow and upstream end of the reservoir because of some degree of mixing in the downstream end of the reservoir. The outlet type and operation of a reservoir also affect the routing of horizontal density currents. As previously discussed in the "Introduction" section, Pueblo Reservoir has a multilevel outlet structure that is capable of releasing water from several depths. However, the majority of flow is released from the river outlet located about $41 \mathrm{ft}$ from the reservoir bottom. During periods that a reservoir is stratified, Ford (1990) indicated that vertical flow can be inhibited and the outflow zone can be restricted to a horizontal layer that can extend the full length of the reservoir. In Pueblo Reservoir, the horizontal layer encompasses a large portion of the reservoir and, during peak outflow, extends most of the length of the reservoir.

Diel variations in the temperature of the Arkansas River result in corresponding diel variations in the initial routing of inflow into the reservoir. The mean diel variation in the temperature of the Arkansas River inflow is about $4.5^{\circ} \mathrm{C}$, and the ranges of water temperature in the river often overlap the water temperature in the reservoir. Therefore, throughout much of the year, it is common for the initial routing of inflow to include overflow, interflow, and underflow during a 24-hour period. During these 24-hour periods, there still can be a dominant direction of inflow routing if the relative density difference between the river and reservoir 

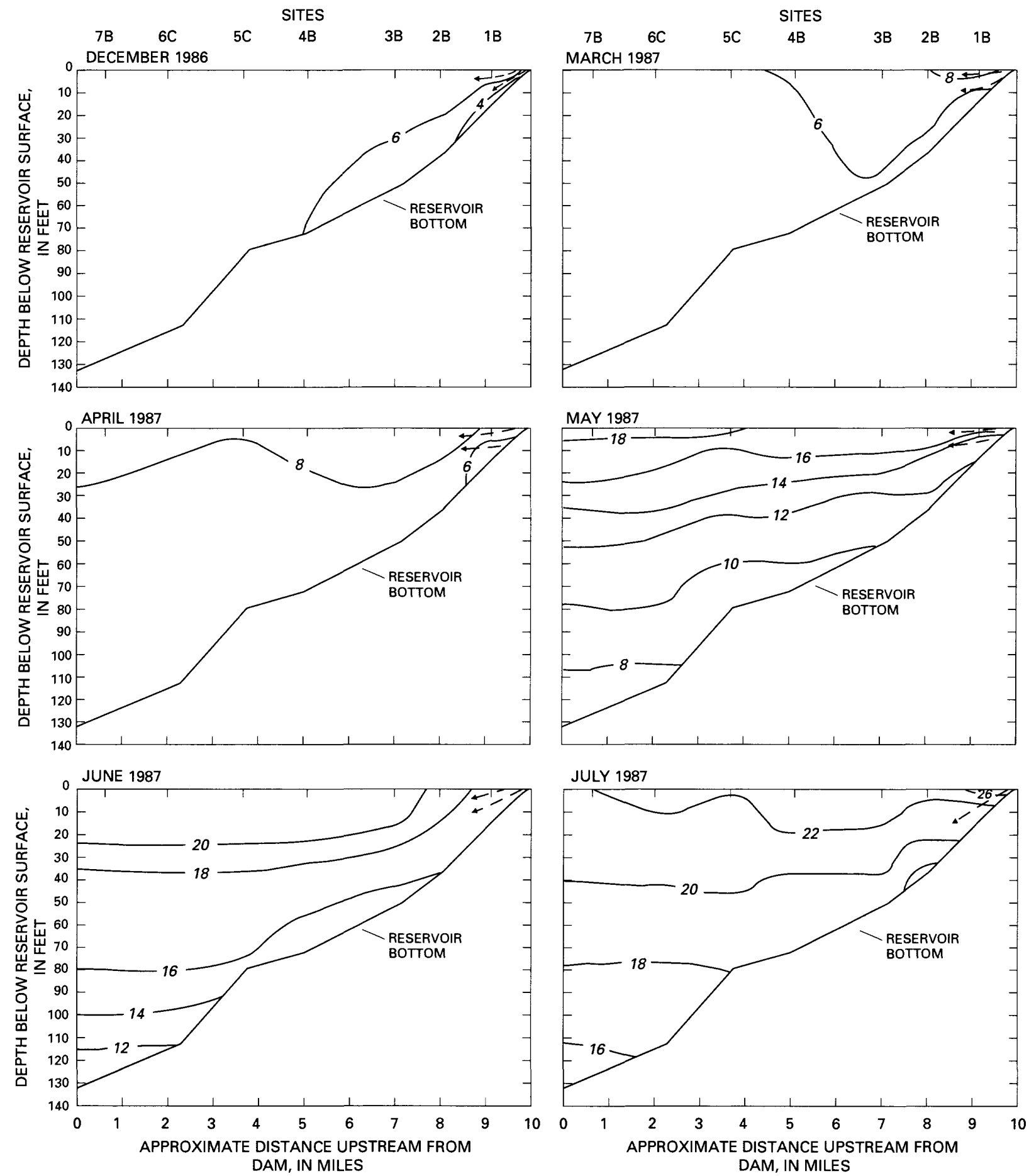

Flgure 4. Monthly temperature profiles for Pueblo Reservoir and initial routing of inflow in Pueblo Reservoir, December 1986 and March through October 1987. 

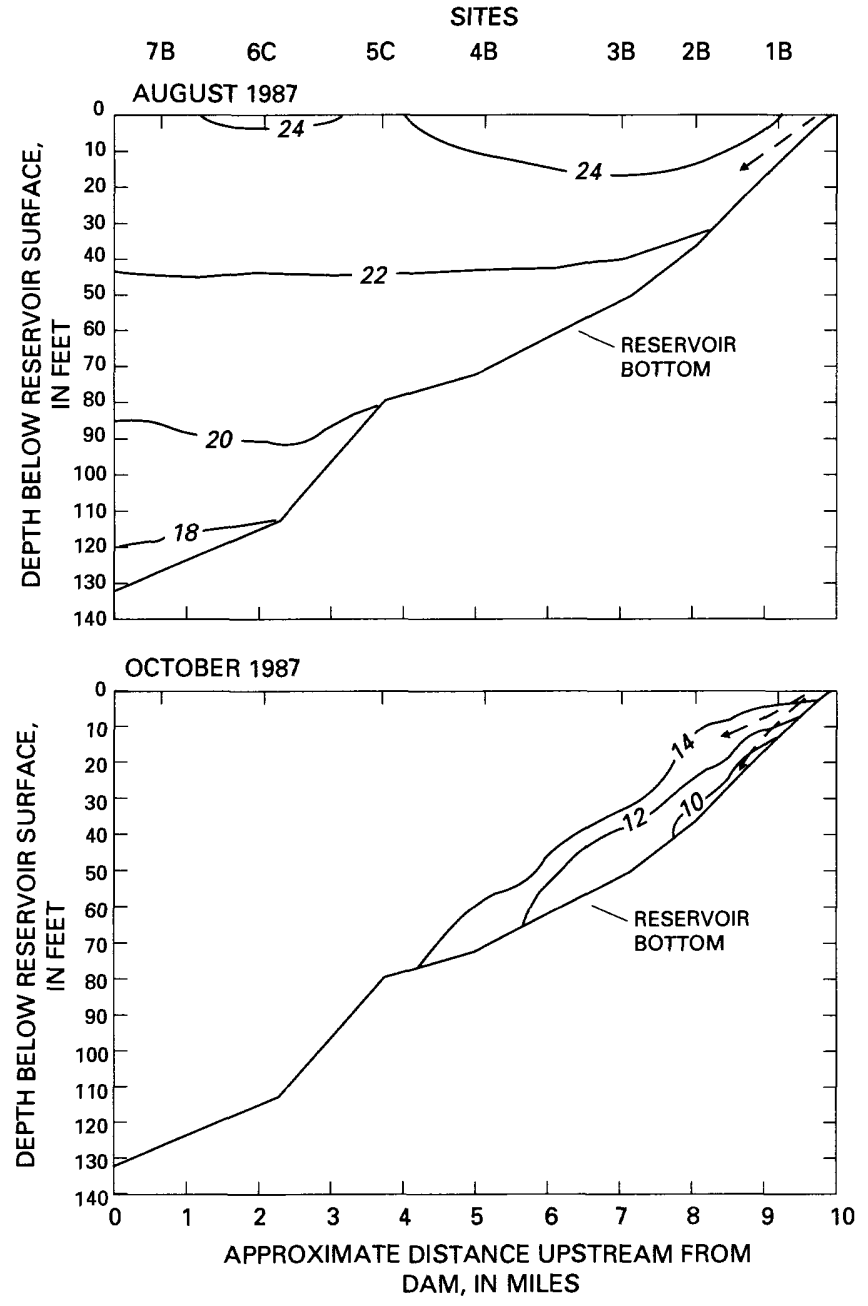

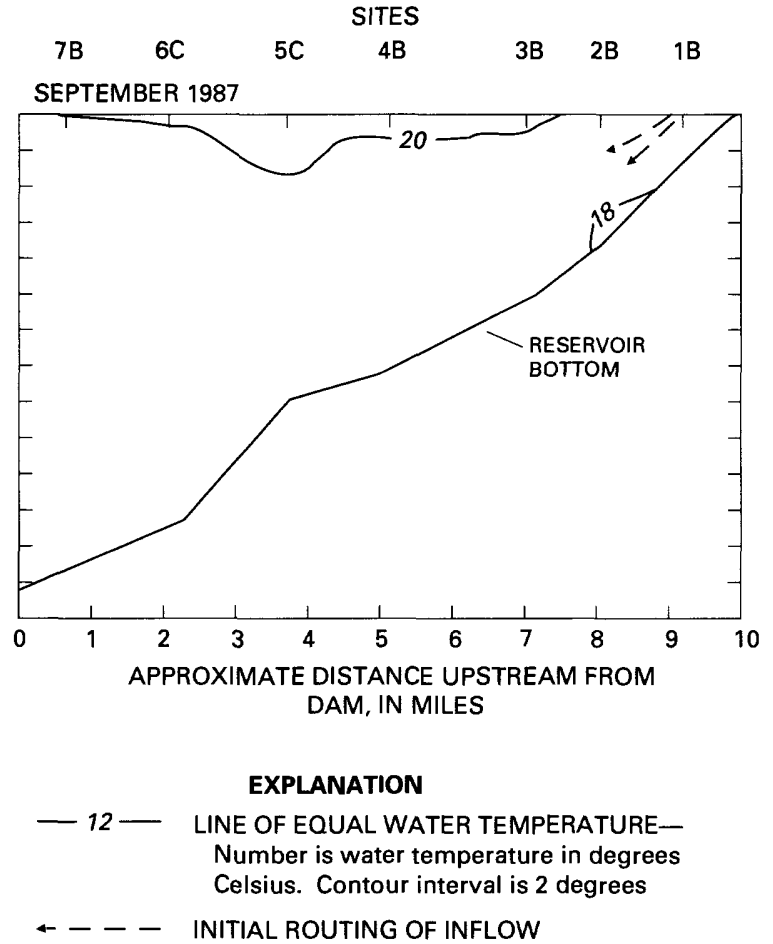

$+-\ldots$ INITIAL ROUTING OF INFLOW

Figure 4. Monthly temperature profiles for Pueblo Reservoir and initial routing of inflow in Pueblo Reservoir, December 1986 and March through October 1987--Continued.

remains nearly constant for a substantial amount of time.

The monthly temperature profiles for December 1986 and March through October 1987 (fig. 4) illustrate the typical temporal and spatial stratification and mixing patterns observed from 1985 through 1989. The December temperature profile indicates the reservoir is fairly well mixed downstream from transect 4 and weakly stratified in the more shallow, upstream part of the reservoir (fig. 4) in early winter. Interflow and underflow of the Arkansas River exists in the upstream part of the reservoir during December. The March temperature profile indicates the reservoir continued to cool during the winter and is well mixed downstream from transect 2 and weakly stratified upstream from transect 2 (fig. 4). The stratified conditions are confined to the shallow, upstream part of the reservoir in early spring, because of rapid warming of the shallow water by solar radiation and interflow of the cooler Arkansas River. Weak stratification dominates the entire reservoir by mid-April as the reservoir surface warms because of increased solar radiation and continued interflow of the Arkansas River. Strong stratification becomes established in the reservoir by mid-May because of reservoir releases from the hypolimnion, increased solar radiation, and interflow of the Arkansas River. The strong stratification persists throughout June, July, and early August as the reservoir surface continues to warm and the Arkansas River enters as increasingly deeper underflow. During this period, the depth of the thermocline increases as deep, cold water is released at the dam and warmer, overlying water replaces it from above. By mid-August, nighttime air temperatures begin to decrease, and stratifica- 
tion in the epilimnion is partially disrupted downstream from transect 3 as the reservoir surface cools and mixes with the underlying water downstream. This process of fall turnover continues into September as air temperatures decrease substantially and can continue into October until the deeper parts of the reservoir generally are well mixed. Underflow of the Arkansas River helps maintain stratified conditions upstream from transect 3 or 4 throughout the fall and winter.

\section{Specific-Conductance Stratification and Mixing Patterns}

Variations in specific conductance in Pueblo Reservoir are a function of the specific conductance and initial routing of the Arkansas River and the thermal stratification and mixing patterns within the reservoir. The specific conductance of the Arkansas River upstream from Pueblo Reservoir varies inversely with discharge. Specific conductance of the river water is lowest in May through early July when discharge is relatively large because of snowmelt runoff in the upper basin. Specific conductance gradually increases with decreasing discharge during the late summer and fall. Matching of observed reservoir specific-conductance values with similar values of antecedent specific conductance of the Arkansas River inflow provides further information on the effect of thermal stratification on the initial routing of inflow into the reservoir and mixing patterns within the reservoir. The determination of stratified or mixed conditions with respect to specific conductance is qualitative; stratification is indicated by a change in specific conductance with depth; wellmixed conditions are indicated by a uniform or nearly uniform specific-conductance profile.

The specific-conductance profiles for December 1986 and March through October 1987 (fig. 5) illustrate the typical temporal and spatial patterns in specific conductance that were measured from 1985 through 1989. These patterns represent those commonly observed in Pueblo Reservoir throughout the year. Specific-conductance stratification patterns are not as well defined as thermal-stratification patterns. With respect to specific conductance, the reservoir generally is well mixed in the winter and early spring (December and March) (fig. 5). The April and May profiles indicate specific-conductance stratification is very weak throughout the reservoir. Specific-conductance stratification becomes well defined in June as underflow becomes the dominant direction of inflow routing, and inflow specific-conductance values decrease at the time of peak snowmelt runoff. Early in the summer, the specific conductance of inflow from the river is relatively low because of snowmelt runoff; therefore, the underflow results in smaller conductance values in the hypolimnion. As summer progresses, the inflow specific conductance in the Arkansas River increases as discharge decreases; as a result, the underflow results in larger specific-conductance values near the reservoir bottom from July through October. Fall turnover mixes the reservoir downstream from about transect 4 during August through September. Generally uniform specific-conductance values in the upper 40 to $70 \mathrm{ft}$ of the downstream part of the reservoir during the late summer and fall indicate these areas are mixing during this time because of fall turnover. Underflow of the Arkansas River maintains relatively strong specificconductance stratification upstream from about transect 4 during the autumn. Relatively stable specific-conductance values in the river inflow and mixing within the reservoir help maintain nearly uniform, well-mixed conditions from late autumn through the spring throughout much of the reservoir.

\section{Reservoir Residence Times}

Residence or retention time is defined as the time necessary for the volume of water in a reservoir to be replaced by inflowing water or the time necessary for the volume of water in a reservoir to be drained by outflow. When the reservoir is well mixed, the residence time can be calculated by using the following equation:

$$
\mathrm{T}=\mathrm{V} / \mathrm{Q}
$$

where

$T$ = residence time, in days;

$\mathrm{V}$ = reservoir volume, in acre-feet; and

$\mathrm{Q}$ = reservoir outflow, in acre-feet per day.

Theoretical residence times for Pueblo Reservoir can range from a few weeks to more than a year (fig. 6). When the reservoir is thermally stratified, the residence time, as calculated from the above equation, does not accurately represent the actual residence time of water entering the reservoir because of various mixing and circulation patterns that occur within the reservoir. Therefore, the equation for estimating theoretical residence time is valid from about October through March or April, although there is some degree of thermal stratification present upstream from about transect 3 during part of this time. Less than 7 percent of the total volume of the reservoir is located upstream from transect 3 when storage is at the top of the conservation pool; therefore, the effects of thermal stratification and underflow in this region on reservoir residence times is small. As a result of the relatively strong thermal strat- 

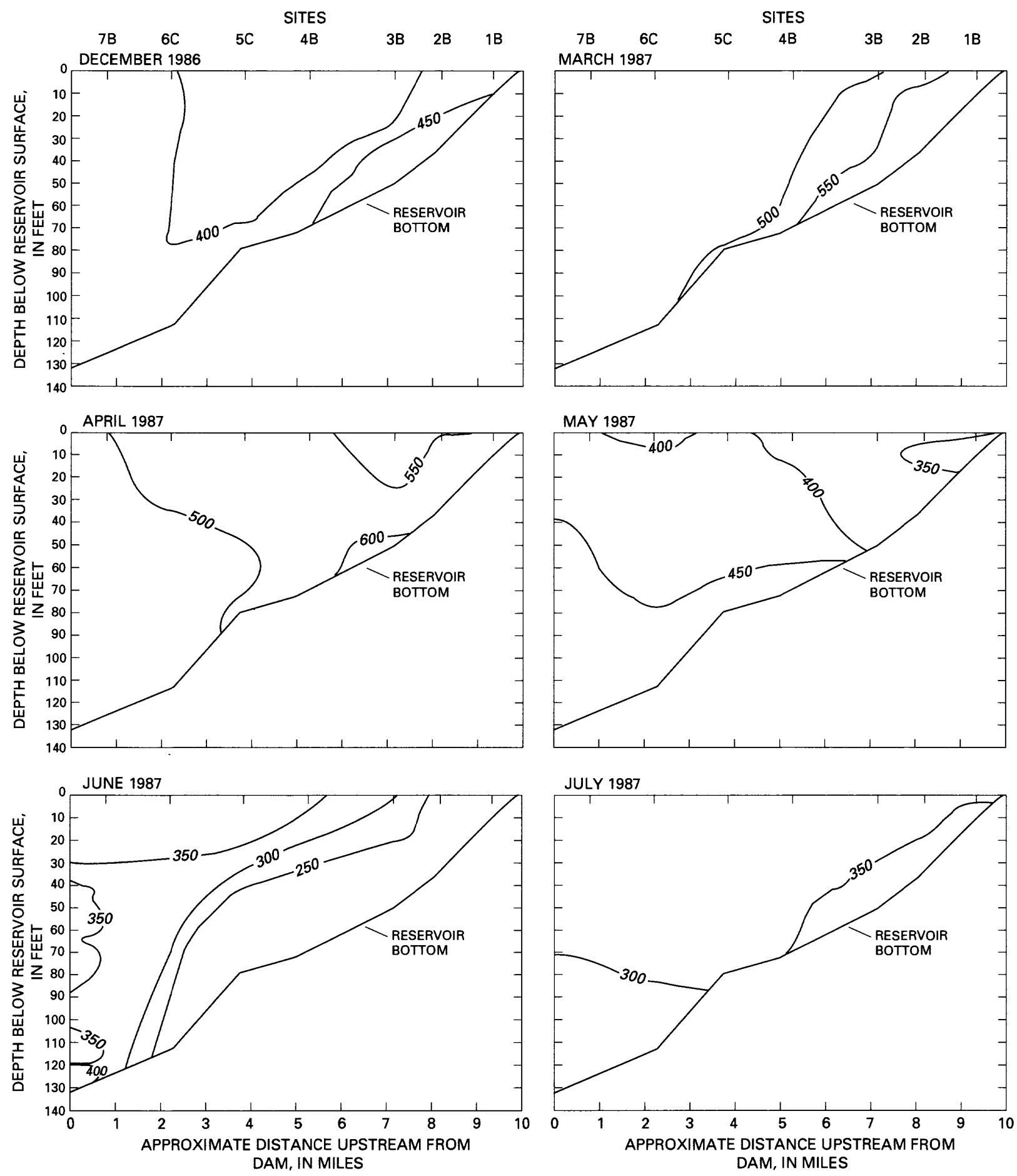

Figure 5. Monthly specific-conductance profiles for Pueblo Reservoir, December 1986 and March through October 1987. 

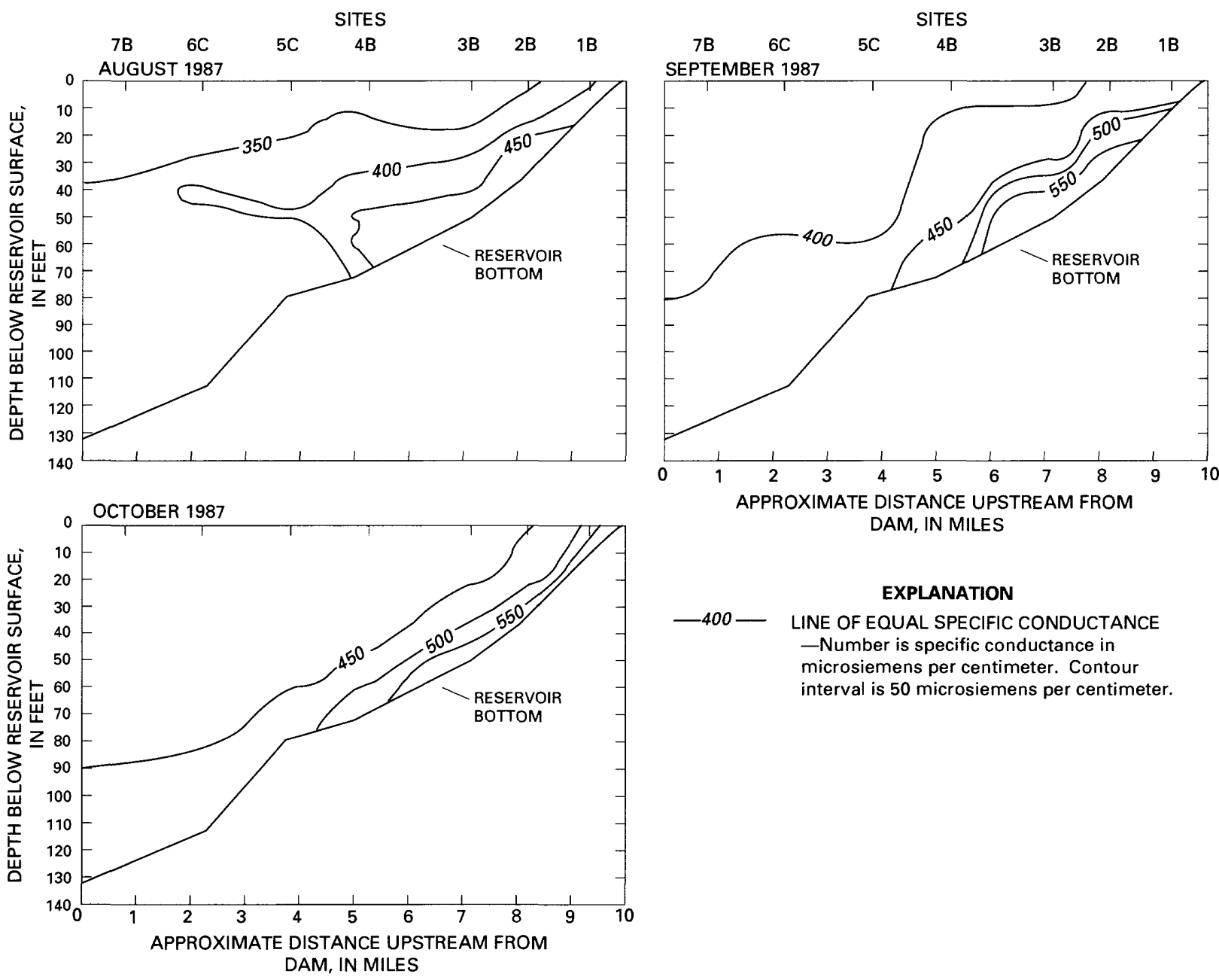

EXPLANATION

-400 - LINE OF EQUAL SPECIFIC CONDUCTANCE

-Number is specific conductance in microsiemens per centimeter. Contour interval is $\mathbf{5 0}$ microsiemens per centimeter.

Figure 5. Monthly specific-conductance profiles for Pueblo Reservoir, December 1986 and March through October 1987--Continued.

ification, underflow, and large reservoir outflow rates from about May to September, the actual residence times of a portion of the reservoir water are considerably shorter than the theoretical residence time. These conditions result in less mixing and dilution of the reservoir inflow before being discharged at the dam. The conditions that result in shorter residence times for inflowing water also can result in longer residence times for a portion of reservoir water. The water with longer residence times might be prevented from mixing with the underflowing water by strong thermal stratification.

Daily reservoir inflow and outflow specificconductance measurements made during 1986 and 1987 were used to estimate the minimum residence times for the reservoir during these years and to indi- cate the potential effect of underflow on reservoir residence times. The minimum residence time was estimated as the elapsed time between the observed minimum specific conductance of the reservoir inflow and outflow (fig. 7). This method could not be effectively applied to 1985,1988 , or 1989 data because of missing data or anomalous patterns in the specificconductance data. In 1986, the minimum residence time was about 30 days and occurred from June 23 to July 22 . The minimum residence time in 1987 was about 31 days and occurred from June 6 to July 6 . The residence times associated with these periods of underflow in 1986 and 1987 represent decreases in the theoretical residence times of about 33 percent and about 31 percent, respectively. 


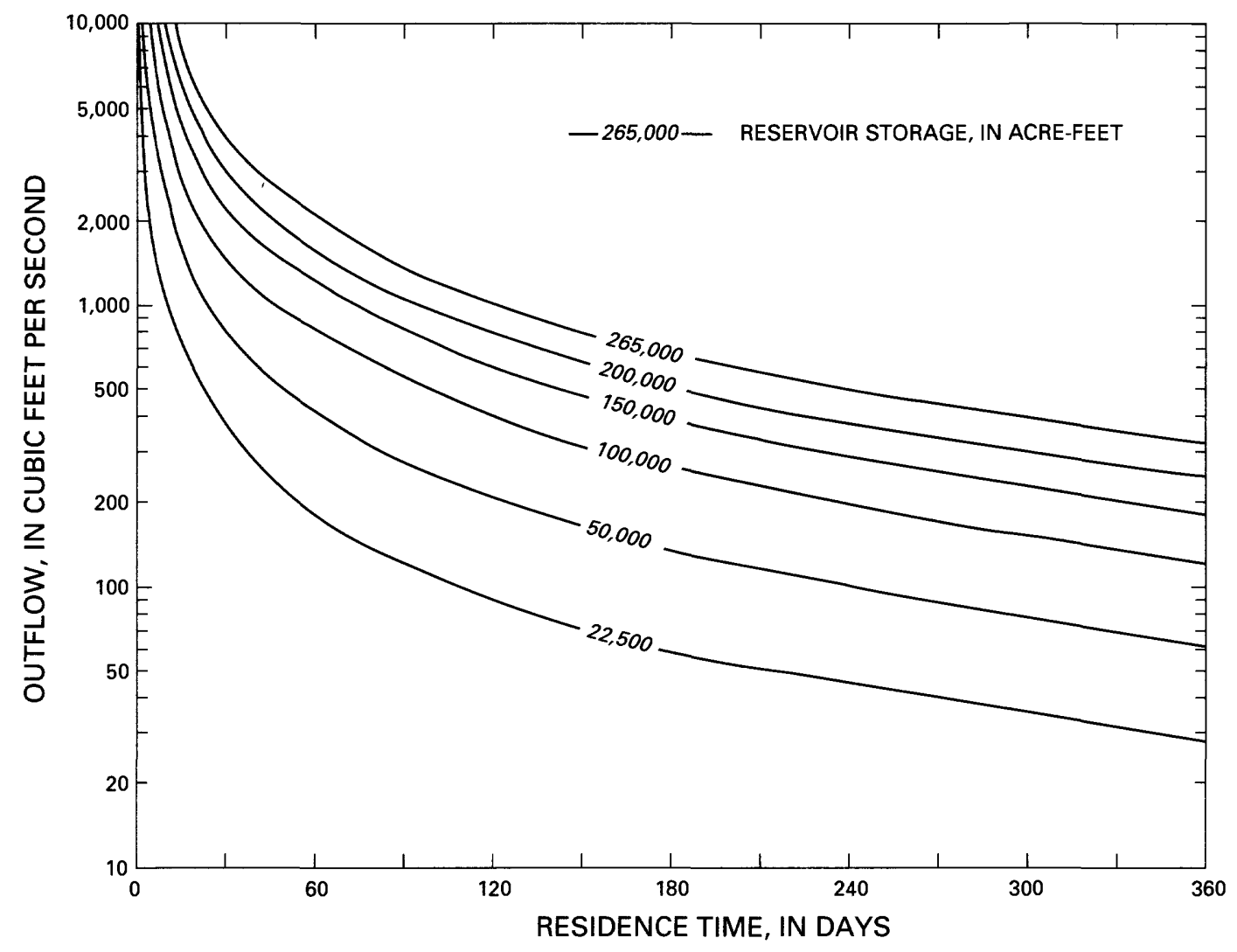

Figure 6. Relation of residence time, outflow, and reservoir storage in Pueblo Reservoir.

\section{Water Transparency}

Water transparency is the capability of water to transmit light and determines the depth of the euphotic zone where sufficient light is available for photosynthesis. Light penetration within the reservoir is limited by suspended inorganic and organic particulate matter. An approximation of the depth of the euphotic zone and the capability of water in Pueblo Reservoir to transmit light was made using a Secchi disk. The depth of the euphotic zone in Pueblo Reservoir can be approximated by multiplying the Secchi-disk depth by two, which is consistent with the relation reported by Moss (1980). The relation between the euphotic zone and Secchi-disk depth is based on a comparison of Secchi-disk measurements to measured compensationzone depths made on July 1, 1986, May 27 and 28, 1987 , and July 28 and 29,1987 . The compensation zone is the depth of water at which oxygen production by photosynthesis equals the oxygen consumption by respiration, which usually occurs when the light intensity is decreased to about 1 percent of the intensity at the surface.
In Pueblo Reservoir, Secchi-disk depths increase in a downstream direction throughout the year (fig. 8) and are consistently larger near the dam than near the inflow. The largest water transparencies and euphoticzone depths occur throughout Pueblo Reservoir from December to late April, a period that corresponds to the minimum annual sediment load to Pueblo Reservoir and the minimum annual biomass. The largest Secchidisk depth $(9.75 \mathrm{~m})$ was recorded at transect 7 during March 1986 (Edelmann and others, 1991).

The capability of the reservoir to transmit light and the depths of the euphotic zone are diminished from late April or May through November (fig. 8). From late April or May through August, water transparency is suppressed because of increased sediment loads to Pueblo Reservoir and an increase in biomass. During this period, the depth of the euphotic zone generally (less than 50 percent of the time) is less than about $2 \mathrm{~m}$ in the upstream part of the reservoir as shown by site $3 \mathrm{~B}$ in figure 8 , less than about $4 \mathrm{~m}$ in the middle part of the reservoir as shown by site $5 \mathrm{C}$, and less than about $5 \mathrm{~m}$ in the downstream part of the reservoir as shown by site $7 \mathrm{~B}$. 


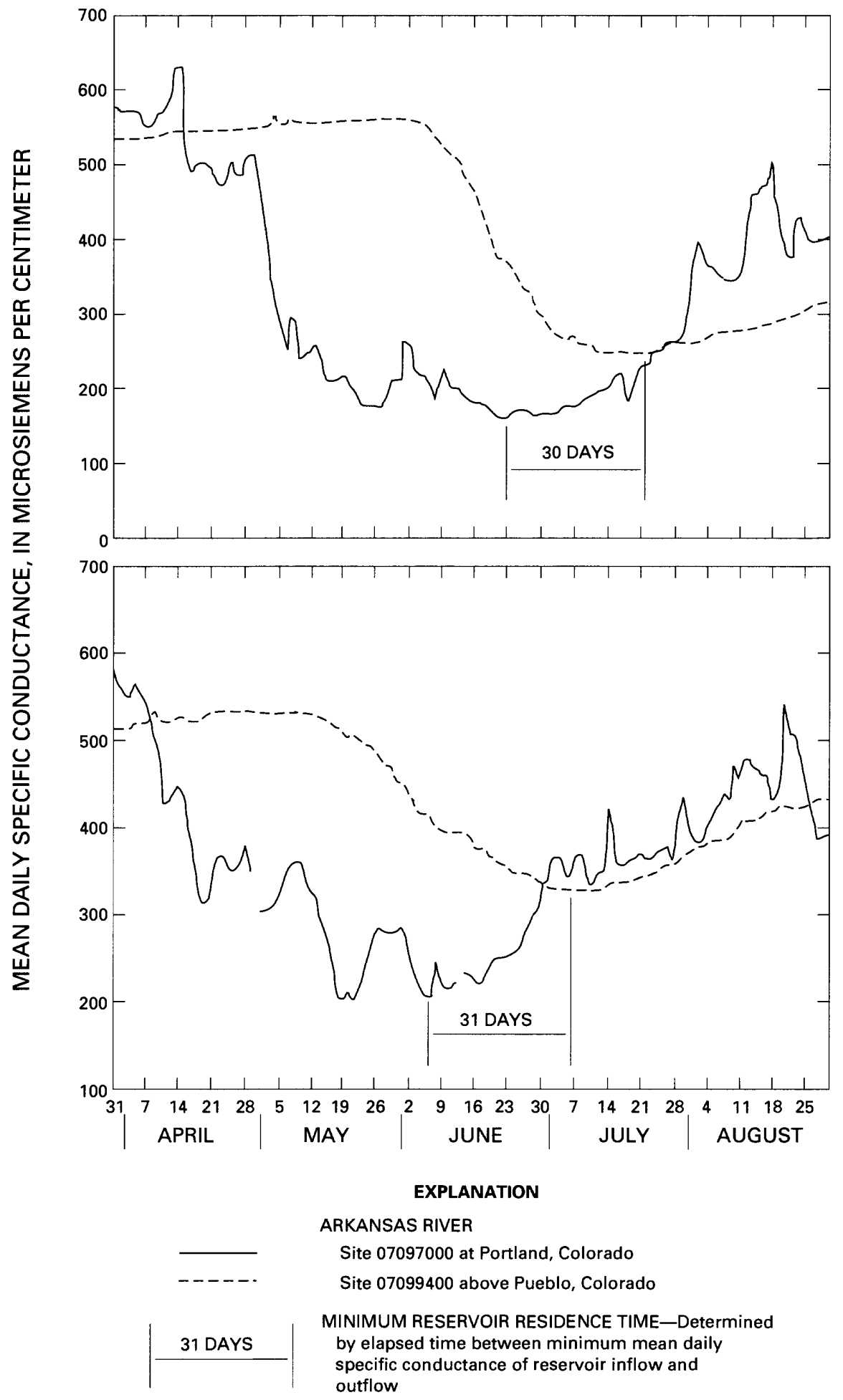

Figure 7. Minimum reservoir residence times using mean daily inflow and outflow specific conductance, 1986 and 1987. 


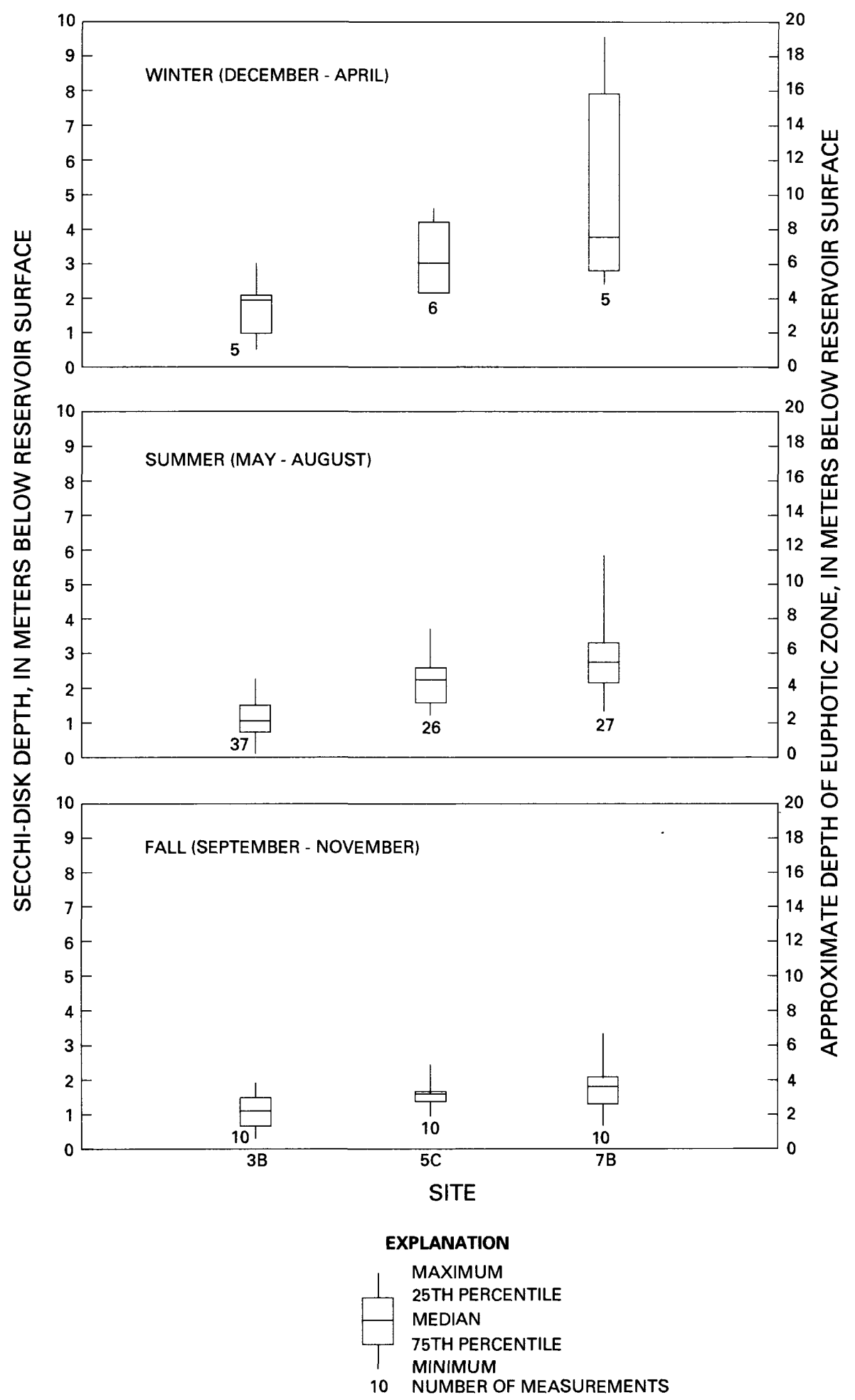

Figure 8. Measurements of Secchi-disk depths and approximate depths of euphotic zone for Pueblo Reservoir, 1985 through 1989. 
Although sediment loads to Pueblo Reservoir are greatly decreased during the fall relative to the summer, and algal biomass generally was smaller during the fall than during the summer, Secchi-disk measurements remained small. Algal biomass seems to be the dominant effect on water transparency during the fall. During the fall, the depth of the euphotic zone generally is less than about $2 \mathrm{~m}$ in the upstream part of the reservoir as shown by site $3 \mathrm{~B}$ in figure 8 , less than about $3 \mathrm{~m}$ in the middle part of the reservoir as shown by site $5 \mathrm{C}$, and less than about $3 \mathrm{~m}$ in the downstream part of the reservoir as shown by site 7B. The persistence of lowwater transparency during the fall might partly be caused by fall turnover resuspending algae and detritus into the euphotic zone that concentrated in the metalimnion during the summer or from fall blooms of phytoplankton, or both.

\section{Distribution and Transport of Particulate Matter}

A semiquantitative method of evaluating distribution and transport of particulate matter in Pueblo Reservoir was made using numerous turbidity measurements made at multiple depths (3-5) and sites in the reservoir (fig. 9). Turbidity is a measurement of the clarity of water and is affected by suspended matter such as clay; silt; finely divided organic matter; soluble, colored, organic compounds; plankton; and other microscopic organisms (American Public Health Association and others, 1985). Although turbidity is an expression of the optical property of water rather than a measurement of the actual suspended-sediment concentration, a comparison of turbidity measurements with concurrent suspended-sediment concentration measurements made from samples collected from the Arkansas River upstream from Pueblo Reservoir (station 07097000, Arkansas River at Portland) indicate a highly significant correlation ( $r^{2}$ of 0.91 at a significance level of 0.0001 ) between turbidity and suspended-sediment concentration.

The predominant sources of suspended material in Pueblo Reservoir are the Arkansas River drainage basin and the production of plankton within the reservoir. Other potential sources of suspended material include resuspension, shoreline erosion, and tributary inflow. The larger size fraction (sand) of suspended sediment within the reservoir settles from the water column relatively quickly. However, the finer size fractions of sediments (clay, silt, and, especially, colloidal material) and organic particulate matter can be transported farther into the reservoir.
The predominant spatial and temporal distribution patterns and transport of particulates in Pueblo Reservoir can be described by using the December 1986 and March through October 1987 turbidity data presented in figure 9 . The majority of the suspended sediment entering Pueblo Reservoir settles out of the water column within about $5 \mathrm{mi}$ from where the river enters the reservoir which, during 1986 and 1987, corresponds to an area between transects 3 and 4 . From October through March, turbidity data collected from Pueblo Reservoir indicate a relatively small amount of suspended matter is present from the Arkansas River during this period. An increase in suspended sediment to Pueblo Reservoir occurs in April and May because of snowmelt runoff from the lower elevations in the upper basin, which results in an increase in particulates throughout the water column in the upstream $5 \mathrm{mi}$ of the reservoir. Most of these sediments settle from the water column within about $3 \mathrm{mi}$ from where the river enters the reservoir which, during 1987 , corresponded to an area between transects 2 and 3 . The remaining sediments are transported about 2 more miles prior to settling out. The turbidity profiles for June through September (fig. 9) are similar to the specificconductance profiles for June through September (fig. 5) and indicate the distribution and transport of particulates in Pueblo Reservoir primarily is affected by the Arkansas River. During June, the peak snowmelt runoff in the upper basin occurs, which results in a large sediment load to the reservoir and a short hydraulic residence time of inflowing water as large volumes of water are released from the reservoir. During this period, underflow also is predominant. Although most particulates settle from the water column within $3 \mathrm{mi}$ from the river inflow, some particulates are transported almost $8 \mathrm{mi}$ into the reservoir which, during 1987, corresponds to transect 6 . As summer progresses, underflow continues to predominate, and hydraulic residence time continues to be short. During this period, most of the suspended material seems to be transported with the underflow and settles from the water column within the upstream $5 \mathrm{mi}$ of the reservoir. However, some particulates are transported through the entire reservoir.

\section{CHEMICAL CHARACTERISTICS}

The chemical processes that occur in Pueblo Reservoir are complex and interrelated with the physical and biological processes. Because of these relations, the chemical characteristics of Pueblo Reservoir vary spatially and seasonally. Water-quality data collected during 1986 through 1989 from Pueblo Reservoir are used to describe the areal, vertical, and 

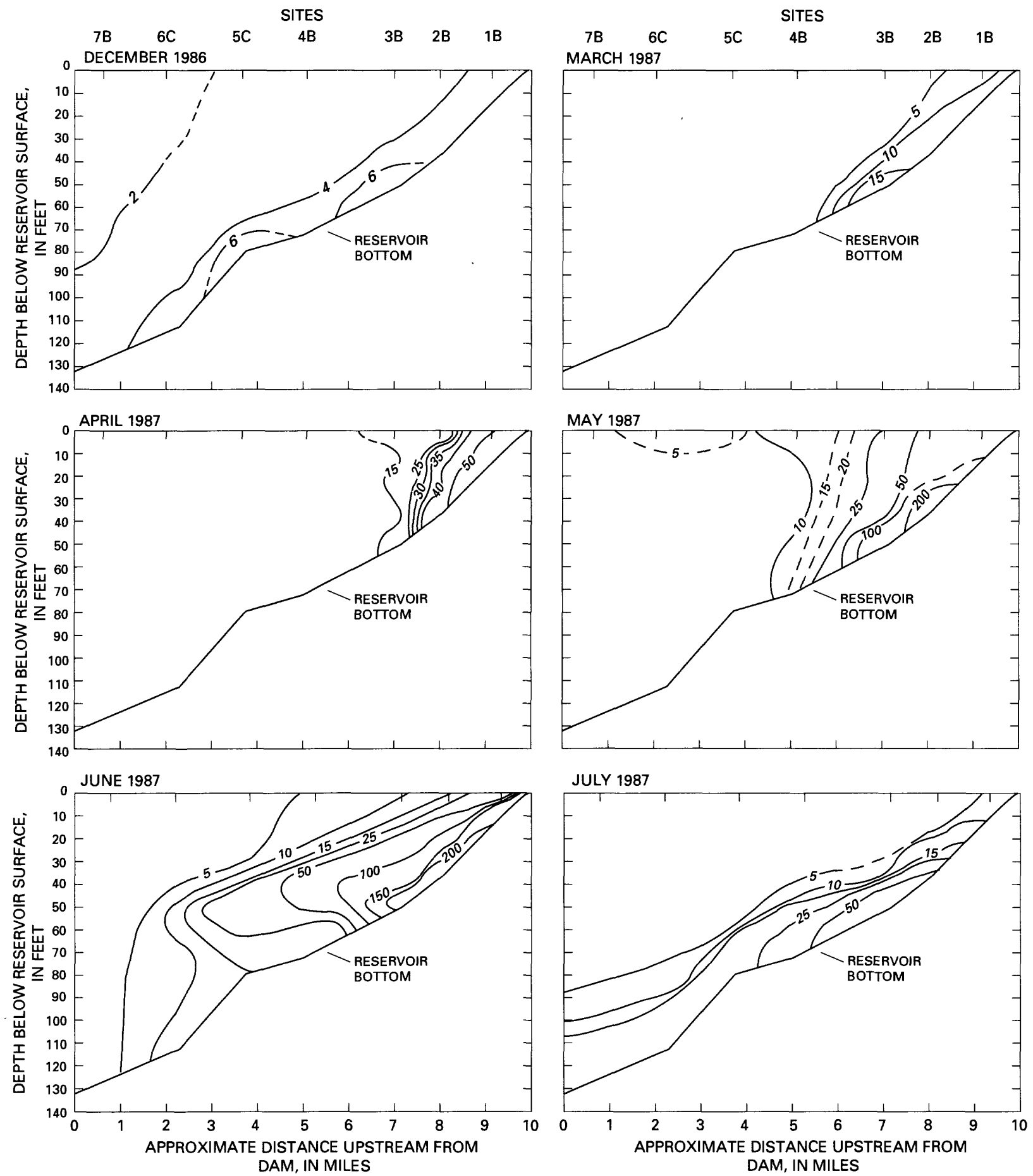

Figure 9. Monthly turbidity-measurement profiles of Pueblo Reservoir, December 1986 and March through October 1987. 

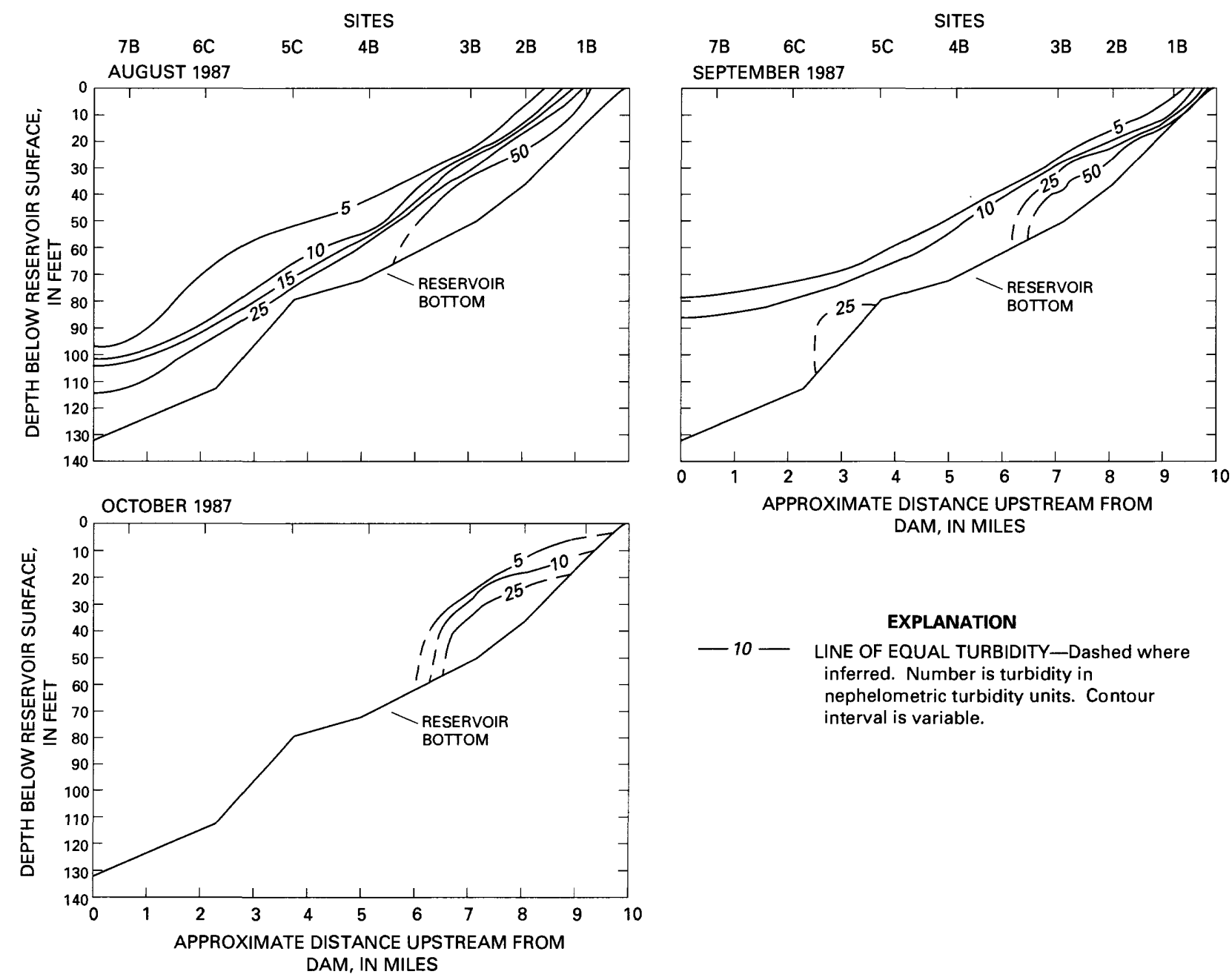

Figure 9. Monthly turbidity-measurement profiles of Pueblo Reservoir, December 1986 and March through October 1987--Continued.

temporal variations of the chemical characteristics of Pueblo Reservoir.

\section{Dissolved Oxygen and pH}

Dissolved-oxygen concentration and $\mathrm{pH}$ are important properties of water. Dissolved oxygen is: (1) essential to the metabolism of most aquatic organisms, (2) necessary for the aerobic decomposition of organic matter, and (3) a controlling factor in the amount of nutrients and trace elements that might be released from the bottom sediments into the water column. Dissolved-oxygen concentrations in Pueblo Reservoir can be affected by photosynthesis, surface aeration, respiration, decomposition, water temperature, and the oxygen content of the Arkansas River.
Inflow from the Arkansas River typically is well oxygenated.

Values of $\mathrm{pH}$ are a measure of the hydrogen-ion activity. The biological activity of many organisms and the solubility of many chemical constituents, including trace elements, are $\mathrm{pH}$ dependent. The $\mathrm{pH}$ of water in Pueblo Reservoir is altered by the processes of photosynthesis and respiration and the $\mathrm{pH}$ of water entering Pueblo Reservoir from the Arkansas River. The $\mathrm{pH}$ of inflow from the Arkansas River typically ranges from 8.1 to 8.8 .

The dissolved-oxygen and $\mathrm{pH}$ data for 1985 through 1989 indicate that dissolved-oxygen concentrations and $\mathrm{pH}$ vary temporally and spatially within the reservoir (Ugland and others, 1988, 1990; Edelmann and others, 1991). Dissolved-oxygen concentrations in the epilimnion are consistently near or greater 
than saturation throughout the reservoir. Dissolvedoxygen concentrations less than $1 \mathrm{mg} / \mathrm{L}$ commonly occur near the reservoir bottom downstream from about transect 5 to the dam in July through midSeptember. The periods of low dissolved-oxygen concentrations typically persist for less than 3 to 4 weeks. Completely anoxic conditions were observed in parts of Pueblo Reservoir on four occasions during 1985 through 1989. Anoxic conditions were measured at site 4B in August 1987, sites 5C and 7B in July 1988, sites 6C and 7B in August 1988, and at site 7B in September 1989. Typically, the anoxic conditions were localized very near the reservoir bottom. The most extensive period of anoxia was during the summer of 1988. In August 1988, the bottom $12 \mathrm{ft}$ of site $6 \mathrm{C}$ and the bottom $30 \mathrm{ft}$ of site 7B were completely anoxic.

An empirical evaluation of available outflow, storage, and dissolved-oxygen data indicates that the onset of depleted dissolved-oxygen concentrations in the hypolimnion is related to the amount of flowthrough that occurs during the snowmelt period, which generally occurs during June. Cole and Hannan (1990) reported the following: (1) anoxia typically originates near the plunge point in the upstream end of many reservoirs and (2) anoxia occurs sooner during high flows because of more rapid displacement of cold hypolimnetic water with warmer water that has smaller dissolved-oxygen concentrations. Anoxia in Pueblo Reservoir does not originate in the upstream end near the plunge point because the inflow is cold and well oxygenated. Additionally, the inflow contains relatively little organic material and has a relatively small biochemical oxygen demand. During 1988, when hydraulic residence times were substantially longer than during 1985 through 1987 and 1989, low dissolved-oxygen concentrations occurred sooner, affected a larger part of the hypolimnion, and resulted in a larger anoxic zone. The onset of low dissolvedoxygen concentrations in Pueblo Reservoir typically occurs downstream from transect 5 and results from the impedance of mixing of deeper hypolimnetic water with the overlying oxygenated density currents of the inflow and outflow zones and the epilimnion. This mixing impedance limits reaeration of depleted hypolimnetic dissolved-oxygen concentrations that result from the decomposition of organic material in the water column and at the sediment-water interface of the reservoir bottom. The deeper hypolimnetic water can be more easily mixed or flushed as part of the outflow by large inflows and outflows than by smaller flows.

The $\mathrm{pH}$ of water in Pueblo Reservoir typically varies spatially and seasonally, and typically ranges from 7.5 to 9.0. Generally, $\mathrm{pH}$ values are largest near the reservoir surface and decrease with increasing depth. Variations in $\mathrm{pH}$ with depth decrease during well-mixed conditions and increase with the onset of strong thermal stratification.

Dissolved-oxygen and $\mathrm{pH}$-measurement profiles of Pueblo Reservoir for March, June, August, and October 1987 illustrate the typical spatial and temporal patterns of dissolved-oxygen concentrations and $\mathrm{pH}$ that occur annually (fig. 10). The March profile is representative of early spring conditions when the reservoir is beginning to warm but is still generally well mixed. During this period, the primary effects on dissolved oxygen and $\mathrm{pH}$ within the water column probably are aeration of the surface water because of wind and wave action and oxygen consumption at the sediment-water interface because of decomposition of organic material and respiration. Some decrease in dissolved-oxygen concentrations occurs with depth apparently because of the limits of vertical mixing. The consumption of dissolved oxygen by the oxidation of organic material and the respiration of plants and animals occur at a faster rate than the oxygen can be supplied by vertical mixing or inflowing upstream water at depths below the euphotic zone (Wetzel, 1983). These oxidative process demands for dissolved oxygen are most intense at the sediment-water interface on the reservoir bottom, where settling organic material accumulates (Wetzel, 1983). The March pH profile indicates the water column was well mixed with respect to $\mathrm{pH}$, and the only change in $\mathrm{pH}$ with depth occurred in the upstream part of the reservoir. The June profiles are representative of the early summer period when strong thermal stratification develops, and primary productivity by phytoplankton is occurring at relatively high rates. Because of the strong thermal stratification, vertical mixing and redistribution of dissolved oxygen within the water column are limited to the epilimnion, and dissolved-oxygen concentrations decrease substantially from the supersaturated conditions at the reservoir surface to concentrations much less than saturation in the hypolimnion. During the summer, the $\mathrm{pH}$ of the water column decreases with depth. The consumption of carbon dioxide during photosynthesis increases the $\mathrm{pH}$ in the epilimnion, whereas the release of carbon dioxide during respiration decreases $\mathrm{pH}$ in the metalimnion and hypolimnion (Wetzel, 1983). The August dissolved-oxygen profile indicates that supersaturated dissolved-oxygen concentrations continue to occur in the epilimnion because of photosynthesis by phytoplankton. Dissolved-oxygen concentrations decrease with depth and are nearly depleted near the reservoir bottom. In 1985 through 1989 , the dissolved-oxygen minimum generally occurred in the hypolimnion at transects 6 and 7 during 

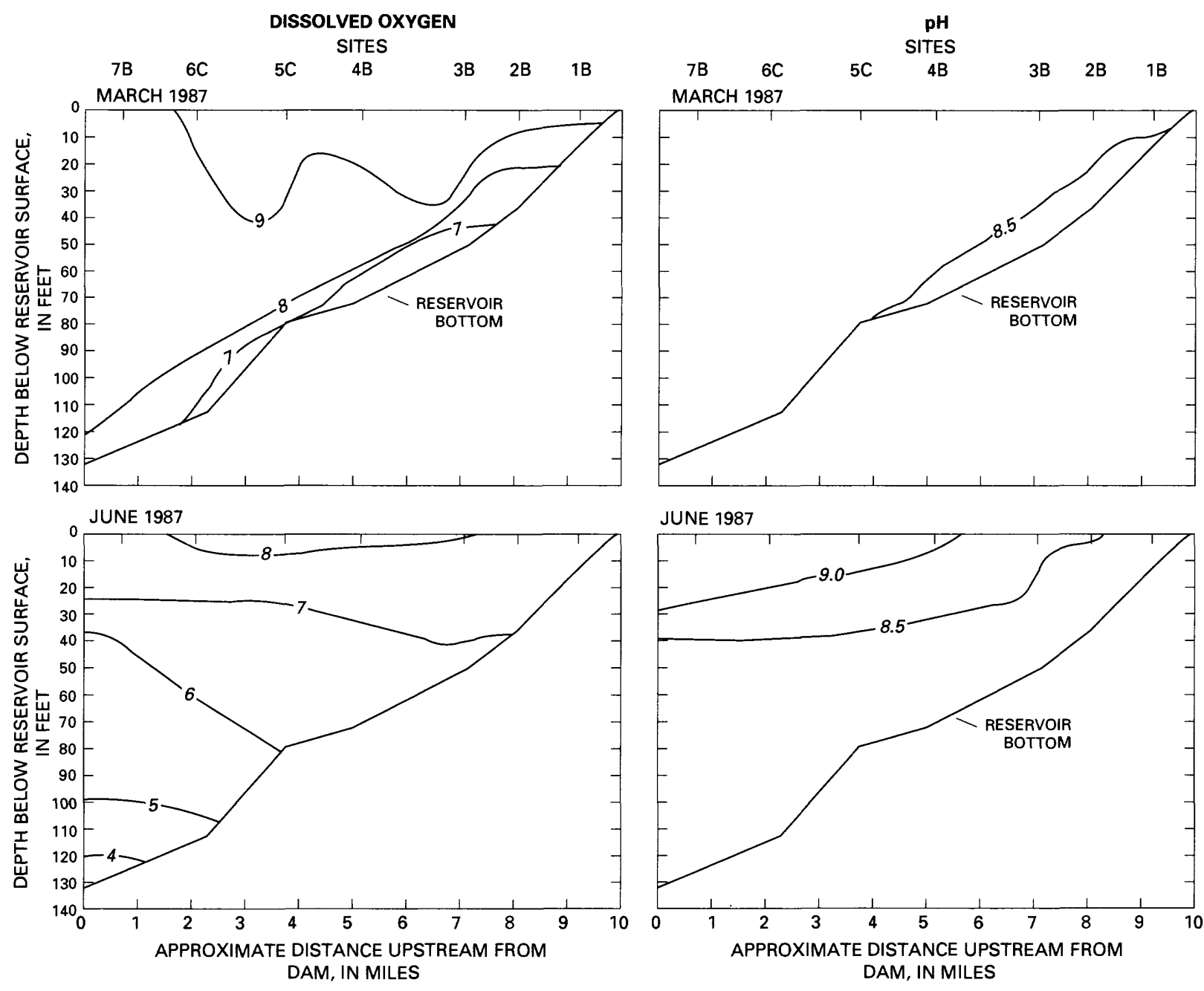

Figure 10. Selected monthly dissolved-oxygen concentration and pH-measurement profiles of Pueblo Reservoir, March, June, August, and October 1987. 

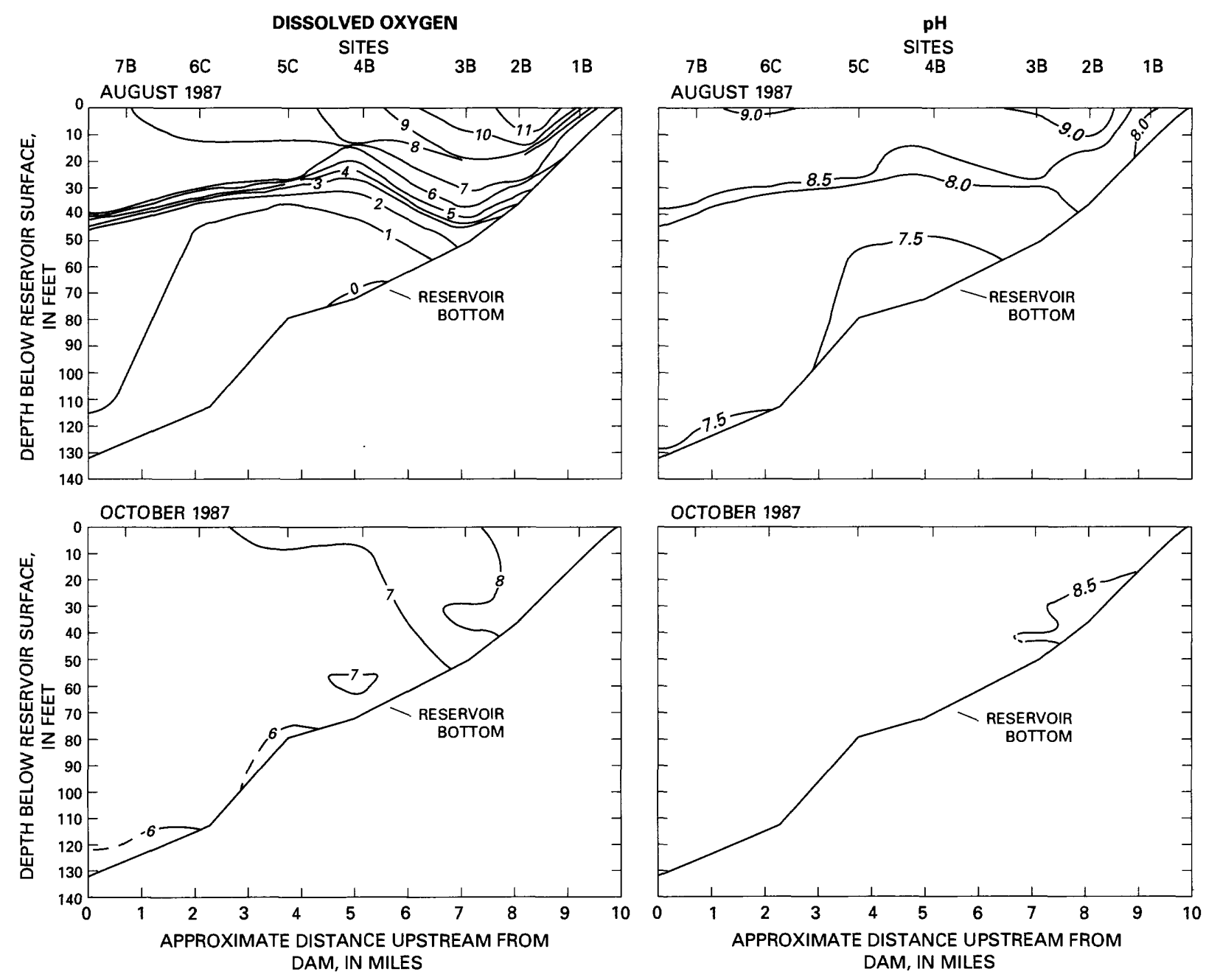

EXPLANATION
$-6-$ LINE OF EQUAL DISSOLVED-OXYGEN
CONCENTRATION-Dashed where
inferred. Number is dissolved-
oxygen concentration, in milligrams per liter.
- 8.5 - LINE OF EQUAL pH-Dashed where inferred. Number is $\mathrm{pH}$ in standard units.

Figure 10. Selected monthly dissolved-oxygen concentration and pH-measurement profiles of Pueblo Reservoir, March, June, August, and October 1987--Continued. 
August. The August 1987 dissolved-oxygen profile indicates concentrations also were nearly depleted in the downstream part of the reservoir near the thermocline. The settling rate of organic matter, phytoplankton, and zooplankton in reservoirs is slowed when it encounters the more dense metalimnetic water, thus, potentially allowing more time for oxygenconsuming decomposition and respiration (Gordon and Skelton, 1977). By October, the reservoir undergoes fall turnover, thus eliminating strong thermal stratification and redistributing dissolved oxygen throughout the water column. A decrease in photosynthesis rates in the colder months results in dissolved-oxygen concentrations less than saturation and $\mathrm{pH}$ values that vary little with depth.

Relatively small diel variations in dissolvedoxygen concentrations and $\mathrm{pH}$ occur in Pueblo Reservoir during the summer (Edelmann and others, 1991). Diel variations that do occur in reservoirs have been attributed to diel changes in rates of photosynthesis and respiration within the water column (Goldman and Horne, 1983). During daylight hours, photosynthesis typically results in increases in dissolved-oxygen concentrations and $\mathrm{pH}$ within the euphotic zone. During nighttime hours, photosynthesis ceases and respiration results in decreases in dissolved oxygen and $\mathrm{pH}$ in the euphotic zone.

\section{Dissoived Soiids}

Dissolved solids is a measure of the quantity of dissolved minerals in water and is used as a measure of inorganic water quality. Large concentrations of dissolved solids can adversely affect water quality for irrigation and municipal use. The major dissolved solids in Pueblo Reservoir include the major ions: calcium, magnesium, sodium, potassium, bicarbonate, sulfate, and chloride. A statistical summary of dissolved solids and major-ion concentrations in the upstream (site 3B), middle (site 5C), and downstream (7B) parts of Pueblo Reservoir is provided in table 2. The concentrations of dissolved solids in Pueblo Reservoir can be affected by the concentration of dissolved solids entering the reservoir from the Arkansas River, reservoir evaporation, diffusion of bottom-sediment pore water, and geochemical controls on mineral solubilities.

Concentrations of most water-quality constituents flowing into Pueblo Reservoir can be estimated with data collected from the Arkansas River about $10 \mathrm{mi}$ upstream from the reservoir (station 07097000 , Arkansas River at Portland); this is not the case for dissolved solids because dissolved-solids concentrations increase by about 10 percent between station 07097000 and the reservoir. Dissolved-solids samples collected at sites IB and 7B in 1986 and 1987 were used to estimate concentrations of dissolved solids in the reservoir inflow and outflow, respectively. The median dissolved-solids concentrations for sites $1 \mathrm{~B}$ and $7 \mathrm{~B}$ during 1986 through 1987 were $224 \mathrm{mg} / \mathrm{L}$ and $262 \mathrm{mg} / \mathrm{L}$, respectively. A statistical analysis of the dissolved-solids concentrations using the MannWhitney test indicates the increase in dissolved-solids concentrations is not significant ( $p$-value $=0.28$ ).

The major-ion composition of water samples from the upstream, middle, and downstream parts of Pueblo Reservoir (sites 3B, 5C, and 7B) are very similar to one another (table 2). Calcium is the dominant cation, and bicarbonate and sulfate are the codominant anions (based on milliequivalents per liter) throughout the reservoir. Relations of dissolved-solids and majorion concentrations to specific conductance were developed for Pueblo Reservoir (table 3). The relations were developed using least-squares regression with a composite of all data collected at sites $3 \mathrm{~B}, 5 \mathrm{C}$, and 7B during 1986 through 1989. All of the equations are significant at the 99-percent confidence level and have coefficients of determination $\left(\mathrm{r}^{2}\right)$ greater than 0.65 , which indicates that dissolved-solids concentrations and individual major-ion concentrations may be accurately estimated with specific-conductance measurements.

A comparison of major-ion concentrations for water samples collected near the reservoir surface and near the reservoir bottom indicates that concentrations of samples collected near the reservoir bottom generally are larger than those collected near the surface. However, the vertical variability in most major-ion concentrations generally is not statistically significant when measured with the Mann-Whitney statistical test (95-percent confidence). Differences between calcium concentrations at the surface and bottom at site $7 \mathrm{~B}$ and bicarbonate concentrations at the surface and bottom at site 3B were significantly different. Geochemical controls might affect the concentrations of calcium within the water column. Modeling of water analyses with the geochemical model WATEQ4F (Ball and Nordstrom, 1991) indicates much of the reservoir typically is supersaturated with calcite, the major source of calcium, throughout the year. Quite often during the summer when $\mathrm{pH}$ values near the reservoir bottom decrease to less than about 7.8, calcite is undersaturated and may result in dissolution of calcite; therefore, calcium concentrations near the reservoir bottom often are significantly larger than near the surface. In other reservoirs, larger bicarbonate concentrations near the reservoir bottom than near the surface have been indicated to be 
Table 2. Statistical summary of dissolved-solids and major-ion concentrations in Pueblo Reservoir, 1986 through 1989 [All concentrations are in milligrams per liter]

\begin{tabular}{|c|c|c|c|c|c|c|c|}
\hline Constituent & $\begin{array}{c}\text { Sampling } \\
\text { site }^{1}\end{array}$ & $\begin{array}{c}\text { Number of } \\
\text { analyses }\end{array}$ & Mean & $\begin{array}{l}\text { Standard } \\
\text { deviation }\end{array}$ & $\begin{array}{l}\text { Twenty- } \\
\text { fifth } \\
\text { percentile }\end{array}$ & Median & $\begin{array}{l}\text { Seventy- } \\
\text { fifth } \\
\text { percentile }\end{array}$ \\
\hline \multirow[t]{3}{*}{ Dissolved solids } & 3B & 44 & 261 & 85.3 & 204 & 251 & 338 \\
\hline & $5 C$ & 44 & 257 & 55.8 & 225 & 256 & 303 \\
\hline & $7 \mathrm{~B}$ & 41 & 269 & 50.4 & 233 & 271 & 317 \\
\hline \multirow[t]{3}{*}{ Calcium } & $3 B$ & 46 & 51 & 13.7 & 40 & 50 & 62 \\
\hline & $5 C$ & 42 & 49 & 8.5 & 43 & 48 & 56 \\
\hline & $7 \mathrm{~B}$ & 44 & 52 & 8.1 & 47 & 52 & 59 \\
\hline \multirow[t]{3}{*}{ Magnesium } & 3B & 46 & 14 & 5.6 & 10 & 13 & 18 \\
\hline & $5 \mathrm{C}$ & 40 & 13 & 3.6 & 10 & 1.2 & 15 \\
\hline & 7B & 44 & 14 & 2.9 & 12 & 14 & 17 \\
\hline \multirow[t]{3}{*}{ Sodium } & 3B & 46 & 19 & 7.9 & 15 & 18. & 25 \\
\hline & $5 C$ & 40 & 17 & 4.6 & 14 & $18^{\circ}$ & 21 \\
\hline & $7 \mathrm{~B}$ & 44 & 19 & 4.7 & 16 & 20 & 22 \\
\hline \multirow[t]{3}{*}{ Potassium } & $3 B$ & 46 & 2.8 & 0.91 & 2.3 & 2.8 & 3.5 \\
\hline & $5 \mathrm{C}$ & 42 & 2.6 & 0.57 & 2.2 & 2.6 & 3.0 \\
\hline & 7B & 44 & 2.7 & 0.49 & 2.3 & 2.9 & 3.2 \\
\hline \multirow[t]{3}{*}{ Bicarbonate } & 3B & 22 & 132 & 35.3 & 94 & 140 & 164 \\
\hline & $5 \mathrm{C}$ & 27 & 106 & 20.6 & 110 & 131 & 149 \\
\hline & 7B & 22 & 129 & 21.2 & 108 & 134 & 144 \\
\hline \multirow[t]{3}{*}{ Sulfate } & 3B & 48 & 101 & 43.4 & 73 & 97 & 124 \\
\hline & $5 C$ & 48 & 99 & 28.7 & 83 & 97 & 117 \\
\hline & $7 \mathrm{~B}$ & 43 & 106 & 27.3 & 84 & 104 & 126 \\
\hline \multirow[t]{3}{*}{ Chloride } & 3B & 46 & 6.6 & 2.3 & 5.0 & 6.2 & 8.4 \\
\hline & $5 C$ & 42 & 6.0 & 1.6 & 5.1 & 5.9 & 7.1 \\
\hline & 7B & 44 & 6.5 & 1.6 & 5.0 & 6.3 & 8.2 \\
\hline
\end{tabular}

the result of uptake of $\mathrm{CO}_{2}$ during photosynthesis by phytoplankton near the reservoir surface (Palmer, 1977).

Differences between major-ion concentrations of reservoir water samples collected in 1986 through 1989 during May through August and those collected during September through April were evaluated to determine if major-ion concentrations vary seasonally (table 4). Large streamflows in the Arkansas River during May through August result in smaller major-ion concentrations entering the reservoir than during September through April, when streamflows are low. Major-ion concentrations of reservoir water samples during May through August were smaller than those during September through April at sites 3B, 5C, and 7B. Most of the differences in seasonal concentrations at sites $3 B$ and $5 \mathrm{C}$ are statistically significant when measured with the Mann-Whitney statistical test (table 4). However, the seasonal differences in major-ion concentrations at site 7B generally were not statistically significant possibly because of mixing induced by fall turnover or reservoir withdrawals. 
Table 3. Relations of dissolved-solids and major-ion concentrations to specific conductance in Pueblo Reservoir

[All dependent variable concentrations in milligrams per liter; SC, specific conductance in microsiemens per centimeter at 25 degrees Celsius]

\begin{tabular}{|c|c|c|c|c|}
\hline \multirow[t]{2}{*}{$\begin{array}{l}\text { Dependent } \\
\text { variable } \\
\text { (V) }\end{array}$} & \multirow[t]{2}{*}{$\begin{array}{l}\text { Num- } \\
\text { ber of } \\
\text { values }\end{array}$} & \multicolumn{2}{|c|}{$\begin{array}{l}\text { Coefficlents in } \\
\text { regression } \\
\text { equation } \\
Y=a+b(S C)\end{array}$} & \multirow{2}{*}{$\begin{array}{l}\text { Coeffi- } \\
\text { cient of } \\
\text { deter- } \\
\text { mination } \\
\left(r^{2}\right)\end{array}$} \\
\hline & & $\mathbf{a}$ & b & \\
\hline Dissolved solids & 129 & -21.8 & 0.666 & 0.99 \\
\hline Calcium & 132 & 8.45 & .097 & .89 \\
\hline Magnesium & 130 & -2.95 & .038 & .86 \\
\hline Sodium & 130 & -5.56 & .056 & .92 \\
\hline Potassium & 132 & -.0224 & .006 & .88 \\
\hline Bicarbonate & 71 & 23.5 & .232 & .68 \\
\hline Sulfate & 128 & -29.7 & .305 & .85 \\
\hline Chloride & 132 & -.593 & .016 & .78 \\
\hline
\end{tabular}

\section{Nitrogen and Phosphorus}

Nitrogen and phosphorus species, commonly referred to as major nutrients, often are the plant nutrients most likely to limit phytoplankton growth. As nutrient concentrations increase, lake and reservoir productivity increases during a process known as eutrophication. Nutrient enrichment of a reservoir is greatly affected by the nature of the drainage basin, because the basin often is a major source of the nutrients, organic matter, and sediment that enters a reservoir (Cooke and others, 1986). The application of fertilizers and discharges of municipal wastewater often are the sources of increased nutrient loads to many lakes and reservoirs. The major sources of nutrients in Pueblo Reservoir probably are the Arkansas River drainage basin and nutrient releases from the reservoir bottom sediments. The major sinks for nutrients in the reservoir include biological uptake and conversion, burial of nutrient-containing sediment and organic matter in reservoir bottom sediments, and outflow from the reservoir.

Nitrogen in freshwater occurs as dissolved molecular nitrogen, ammonia, nitrate, nitrite, urea, and dissolved organic nitrogen compounds. Dissolved inorganic nitrogen, which includes ammonia and nitrate, is the major nitrogen form that is readily available to bacteria, fungi, and plant growth in aquatic ecosystems (Goldman and Horne, 1983). Wetzel (1983) reported that the total phosphorus content of lake water, which includes dissolved and particulate inorganic and organic forms, is considered the most important phosphorus quantity relative to the overall metabolic
Table 4. Results of Mann-Whitney test of seasonal differences between dissolved-solids concentrations in Pueblo Reservoir, 1986 through 1989

[HS, highly significant ( $<<0.01)$; $S$, significant $(p<0.10)$; NS, not significant $(p>0.10)$ ]

\begin{tabular}{|c|c|c|c|c|}
\hline \multirow{2}{*}{$\begin{array}{l}\text { Sampling } \\
\text { site }^{1}\end{array}$} & \multicolumn{2}{|c|}{$\begin{array}{l}\text { Median concentration, } \\
\text { in milligrams per liter }\end{array}$} & \multirow{2}{*}{ p-value } & \multirow{2}{*}{$\begin{array}{l}\text { Signifi- } \\
\text { cance of } \\
\text { concen- } \\
\text { tration } \\
\text { difference }\end{array}$} \\
\hline & $\begin{array}{l}\text { May - } \\
\text { August }\end{array}$ & $\begin{array}{c}\text { September - } \\
\text { April }\end{array}$ & & \\
\hline \multicolumn{5}{|c|}{ Dissolved solids } \\
\hline $3 B$ & 205 & 343 & 0.00 & HS \\
\hline $5 C$ & 232 & 292 & .00 & HS \\
\hline $7 B$ & 260 & 289 & .19 & NS \\
\hline \multicolumn{5}{|c|}{ Calcium } \\
\hline $3 B$ & 41 & 63 & .00 & HS \\
\hline $5 C$ & 45 & 54 & .00 & HS \\
\hline $7 B$ & 50 & 55 & .24 & HS \\
\hline \multicolumn{5}{|c|}{ Magnesium } \\
\hline $3 B$ & 10 & 18 & .00 & HS \\
\hline $5 C$ & 12 & 15 & .00 & HS \\
\hline $7 \mathrm{~B}$ & 14 & 15 & .07 & $S$ \\
\hline \multicolumn{5}{|c|}{ Sodium } \\
\hline $3 B$ & 15 & 25 & .00 & HS \\
\hline $5 \mathrm{C}$ & 16 & 21 & .00 & HS \\
\hline $7 \mathrm{~B}$ & 19 & 21 & .32 & NS \\
\hline \multicolumn{5}{|c|}{ Potassium } \\
\hline $3 B$ & 2.4 & 3.5 & .00 & HS \\
\hline $5 C$ & 2.2 & 3.0 & .00 & HS \\
\hline $7 \mathrm{~B}$ & 2.6 & 2.9 & .16 & NS \\
\hline \multicolumn{5}{|c|}{ Bicarbonate } \\
\hline $3 B$ & 91 & 155 & .01 & $S$ \\
\hline $5 \mathrm{C}$ & 105 & 140 & .02 & $\mathbf{S}$ \\
\hline $7 B$ & 120 & 140 & .13 & NS \\
\hline \multicolumn{5}{|c|}{ Sulfate } \\
\hline $3 B$ & 75 & 125 & .00 & HS \\
\hline $5 \mathrm{C}$ & 86 & 110 & .00 & HS \\
\hline $7 B$ & 100 & 110 & .29 & NS \\
\hline \multicolumn{5}{|c|}{ Chloride } \\
\hline $3 B$ & 5.5 & 8.5 & .00 & HS \\
\hline $5 \mathrm{C}$ & 5.2 & 6.4 & .01 & $S$ \\
\hline $7 \mathrm{~B}$ & 6.4 & 6.2 & .50 & NS \\
\hline
\end{tabular}

characteristics of a lake. But, with respect to reservoir productivity and eutrophication, orthophosphorus is the phosphorus form of most concern, because it is immediately available for algal production (Walter Rast, United Nations Environmental Programme, written commun., 1993). 
Demands are placed on nutrient concentrations in the euphotic zones of temperate-zone reservoirs (such as Pueblo Reservoir) by phytoplankton during intense periods of growth or blooms, which typically begin in the spring and continue into fall (Goldman and Horne, 1983). The demand on nutrient concentrations generally decreases substantially during the colder months, typically October through April, when sunlight and water temperatures decrease. During the summer in biologically productive reservoirs, when thermal stratification is well established in the reservoir and dissolved-oxygen concentrations become very low or depleted in the hypolimnion, mobilization of nutrients from the bottom sediments occurs. The nutrients released from the bottom sediments may be discharged from the reservoir in deep-water withdrawals or redistributed throughout the water column following fall turnover.

In 1986 through 1989, the median concentration of dissolved inorganic nitrogen at sites 3B, 5C, and 7B ranged from 0.07 to $0.10 \mathrm{mg} / \mathrm{L}$ near the surface and from 0.19 to $0.30 \mathrm{mg} / \mathrm{L}$ near the bottom during May through September (fig. 11). Inorganic nitrogen concentrations in water samples collected from near the reservoir surface did not vary much between the upstream and downstream parts of the reservoir and generally were smaller than the dissolved inorganic nitrogen concentrations in samples collected near the bottom of the reservoir during May through September probably because of biological uptake of nitrogen in the epilimnion, underflow of nitrogen from the Arkansas River, and bottom-sediment releases of ammonia. The effect of bottom releases of nitrogen to the hypolimnion is most evident at site 7B, where inorganic nitrogen concentrations were substantially larger than at sites 3B and 5C. During October through April, the median dissolved inorganic nitrogen concentrations ranged from 0.17 to $0.24 \mathrm{mg} / \mathrm{L}$ near the surface and near the bottom (fig. 11). There is little variation between the surface and bottom concentrations of dissolved inorganic nitrogen during October through April, because (1) the reservoir generally is well mixed following fall turnover, (2) the reservoir is well oxygenated, thus, decreasing the flux rate of nitrogen from the bottom sediments, and (3) the biological uptake of nitrogen in the euphotic zone is decreased during the colder months.

In 1986 through 1989, the median concentration of total phosphorus at sites 3B, 5C, and 7B ranged from 0.015 to $0.04 \mathrm{mg} / \mathrm{L}$ near the reservoir surface and from .032 to $.053 \mathrm{mg} / \mathrm{L}$ near the reservoir bottom during May through September (fig. 12). During October through April, median concentrations of total phosphorus ranged from .013 to $.031 \mathrm{mg} / \mathrm{L}$ near the reservoir surface and from .012 to $.039 \mathrm{mg} / \mathrm{L}$ near the reservoir bottom (fig. 12). Total phosphorus concentrations typically are larger during May through September than during October through April. The seasonal variation probably is caused by larger phosphorus concentrations in the inflow during May through September and releases of phosphorus from the bottom sediments during the summer. Throughout the year, concentrations of total phosphorus decrease in a downstream direction probably because of sedimentation of the particulate matter on which phosphorus is sorbed and uptake of dissolved phosphorus by phytoplankton. Concentrations of total phosphorus typically are larger near the reservoir bottom than near the surface probably because of underflow of phosphorus from the Arkansas River, settling of particulate matter, phosphorus releases from the bottom sediments, and photosynthetic demands for dissolved orthophosphate by phytoplankton in the euphotic zone.

Dissolved orthophosphorus data collected in 1987 and 1989 indicate concentrations near the reservoir surface decrease downstream from the upper part of the reservoir (site 3B, fig. 13). The decrease probably results from uptake and removal of most of the incoming orthophosphorus by phytoplankton in the euphotic zone in the upstream end of the reservoir. This is consistent with the concept of longitudinal chemical and biological zonation in a reservoir reported by Kimmel and others (1990), which suggests that the largest phytoplankton production occurs just downstream from the "plunge point" in a reservoir and decreases toward the dam end of a reservoir. Dissolved-orthophosphate concentrations near the reservoir bottom changed very little throughout the reservoir. The lack of variation in dissolved-orthophosphate concentration near the reservoir bottom probably is the result of the lack of biological uptake of nutrients in the hypolimnion and the flux of phosphorus from the bottom sediments replenishing the phosphorus that sorbs to particulate matter and settles from the water column.

Nutrient loading to Pueblo Reservoir was analyzed for 1986 and 1987 (table 5). Total-nitrogen and total-phosphorus loads were computed for two periods: (1) the more biologically active period, May through September, and (2) the colder, less biologically active period, October through April. Data for the computation of nutrient loads in the reservoir inflow and outflow were collected at Arkansas River at Portland (station 07097000) and Arkansas River above Pueblo (station 07099400), respectively. Loads were computed as the product of total streamflow and the median nutrient concentration for each period. Loads were computed for the two periods to account for any sea- 


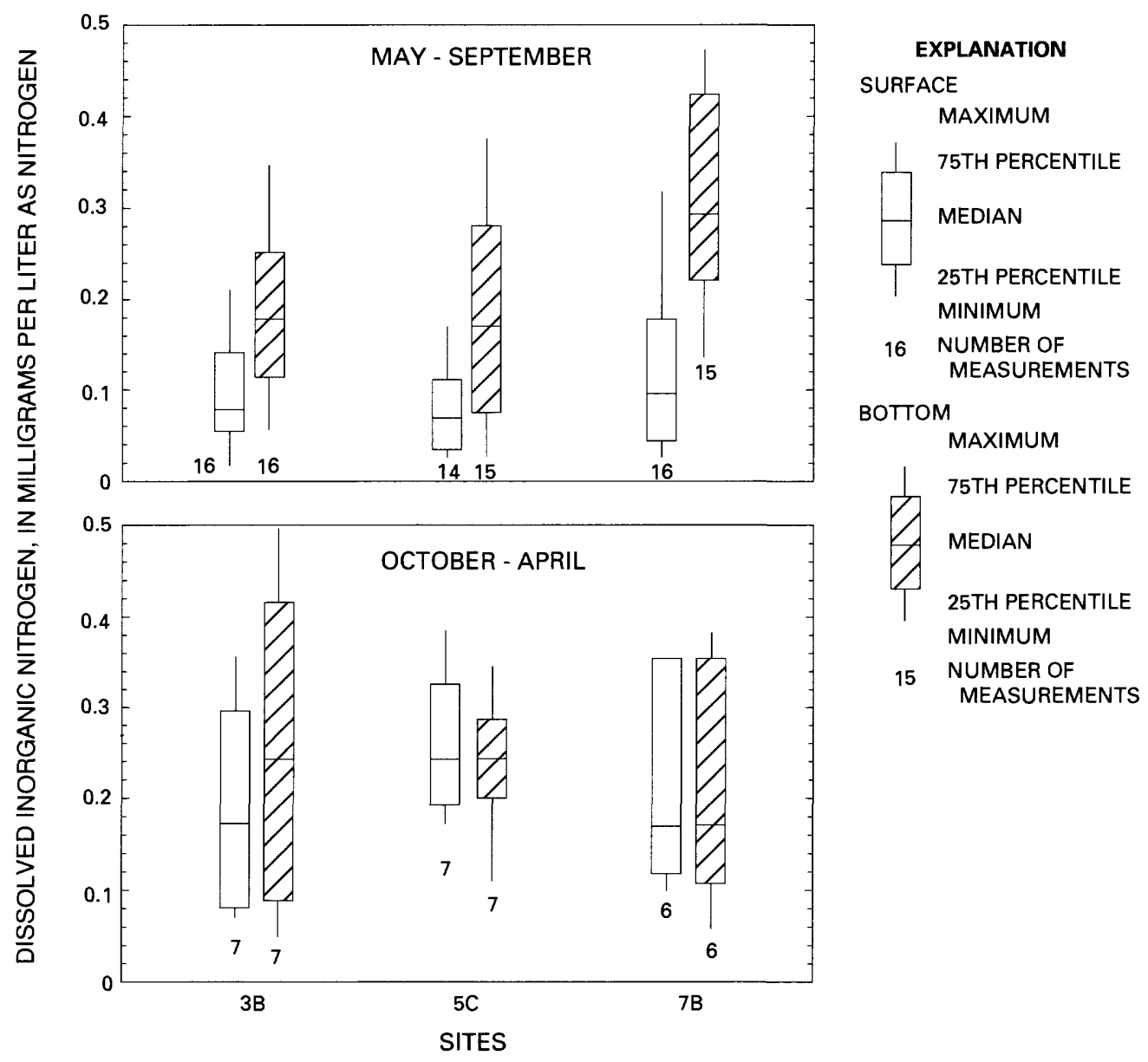

Figure 11. Dissolved-inorganic nitrogen concentrations in Pueblo Reservoir near the reservoir surface and near the reservoir bottom, 1986 through 1989.

sonal differences in streamflow and subsequently in nutrient loads.

Comparison of estimated nutrient loads in the inflow and outflow indicate the reservoir retained about 359 tons of nitrogen and about 203 tons of phosphorus during 1986 and 1987 (table 5). The nutrients retained represent about 35 percent of the total nitrogen and about 83 percent of the total phosphorus load to the reservoir. Most of the total nitrogen load is in the form of dissolved nitrogen and is less subject to removal by sedimentation. Most of the total phosphorus load is in the particulate form and settles from the water column within the reservoir. About 52 percent of the total annual nitrogen load and about 78 percent of the total annual phosphorus load in the reservoir inflow entered during May through September. The larger nutrient loads during this period largely are a function of increased streamflow during the snowmelt- and summer-storm-runoff periods.
Flux of nutrients from the reservoir bottom sediments can constitute a substantial nutrient load for the reservoir. Flux rates for inorganic nitrogen and phosphorus from the bottom sediments to the water column were estimated from samples of bottom-sediment interstitial pore water that were collected from several locations in the reservoir during 1987, 1988, and 1990. Flux rates were calculated with the equation for Fick's first law (Thibodeaux, 1979). In the six samples collected and analyzed for inorganic nitrogen, the mean concentration of inorganic nitrogen in the upper $1 \mathrm{~cm}$ of the sediment was $1.8 \mathrm{mg} / \mathrm{L}$. The mean inorganic nitrogen concentration in the overlying hypolimnion was $0.03 \mathrm{mg} / \mathrm{L}$. The mean flux rate for inorganic nitrogen was estimated to be about $30 \mathrm{mg} / \mathrm{m}^{2} /$ day. In four bottom-sediment samples, the mean inorganic phosphorus concentration in the upper $1 \mathrm{~cm}$ of the sediment was $0.09 \mathrm{mg} / \mathrm{L}$. The mean inorganic phosphorus concentration in the overlying hypolimnion was 


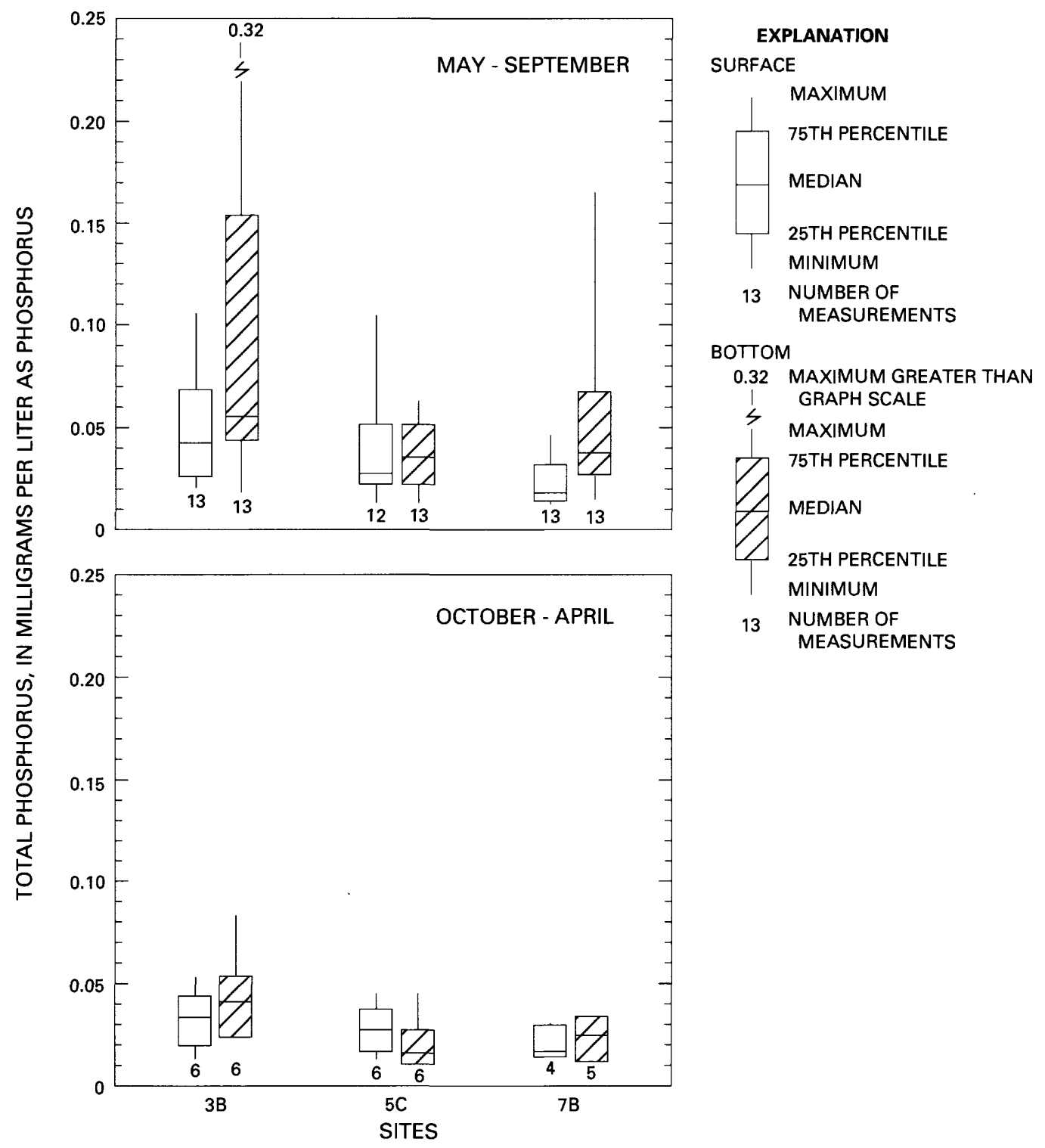

Flgure 12. Total phosphorus concentrations in Pueblo Reservoir near the reservoir surface and near the reservoir bottom, 1986 through 1989.

$0.007 \mathrm{mg} / \mathrm{L}$. The mean flux rate for the four samples was about $0.44 \mathrm{mg} / \mathrm{m}^{2} /$ day. Because of the small number of samples collected, the above mean flux rates might not represent the spatial and temporal variation in nutrient flux rates that are expected to occur in the reservoir and, therefore, were not used to estimate annual nutrient-load contributions from the bottom sediments. The samples for these estimates were collected in August, September, and October during periods when dissolved-oxygen concentrations were less than $3 \mathrm{mg} / \mathrm{L}$ in the hypolimnion. Flux rates are expected to decrease during the well-oxygenated periods and increase during periods of complete and prolonged anoxia. Therefore, nutrient flux from the bottom sediments can represent a substantial nutrient source for the reservoir during the summer and fall, especially during anoxic periods in the hypolimnion.

Although major nutrients, trace elements, light availability, and temperature are all important growthregulating variables for phytoplankton in lakes and reservoirs, it is widely accepted that the major nutrients, phosphorus and nitrogen, are the most common 

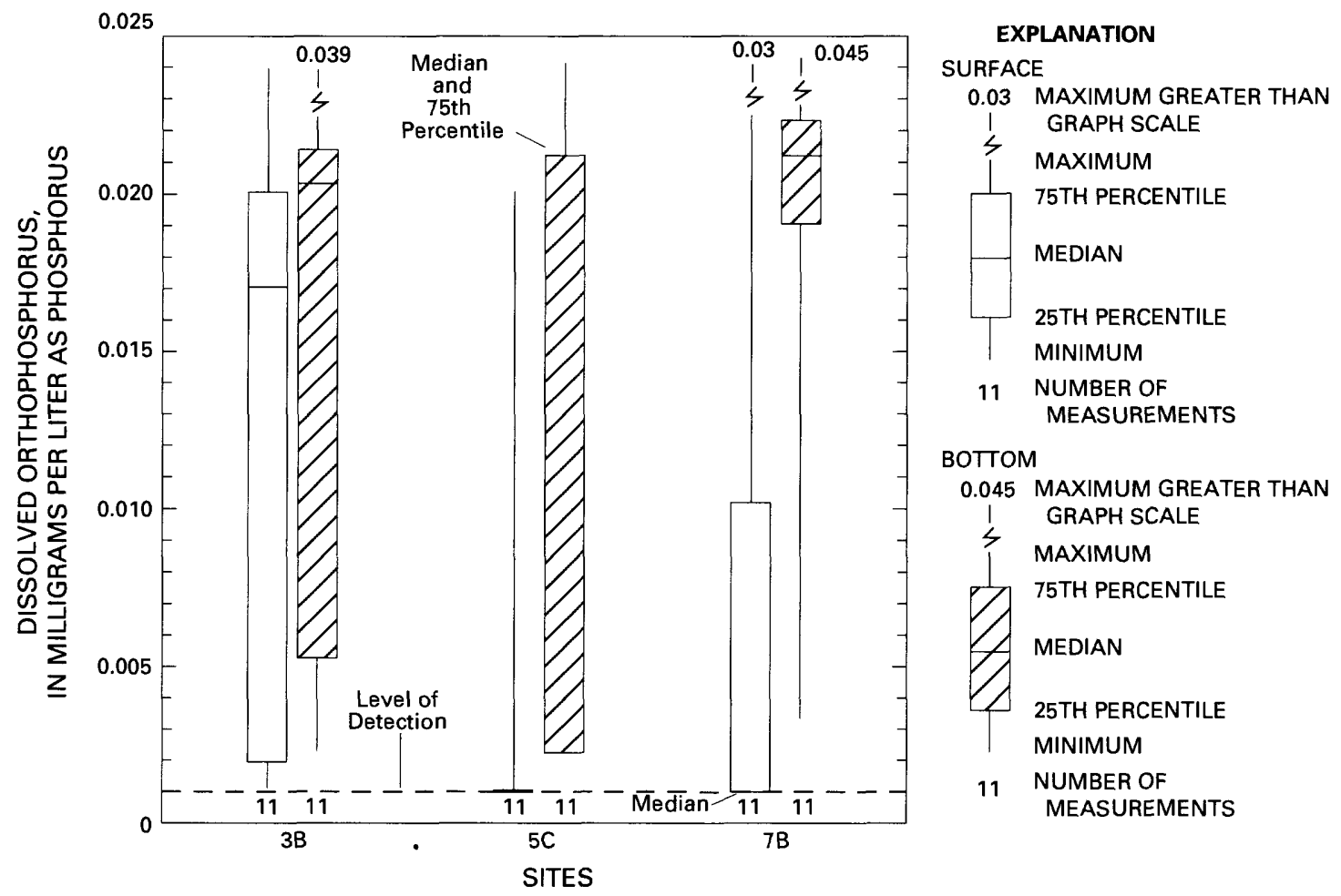
BOTTOM
0.045 MAXIMUM GREATER THAN

I GRAPH SCALE

S MAXIMUM

75TH PERCENTILE

14 MEDIAN

25th percentile

MINIMUM

11 NUMBER OF

MEASUREMENTS

Figure 13. Dissolved-orthophosphorus concentrations in Pueblo Reservoir near the reservoir surface and near the reservoir bottom, 1987 and 1989.

Table 5. Estimated loads of total nitrogen and total phosphorus in Pueblo Reservoir inflow and outtlow, 1986 and 1987

\begin{tabular}{lccccc}
\hline & \multicolumn{3}{c}{ Constituent load, in tons } \\
\cline { 2 - 3 } & \multicolumn{2}{c}{ Total nitrogen } & & \multicolumn{2}{c}{ Total phosphorus } \\
\cline { 2 - 3 } \cline { 5 - 6 } & Inflow & Outflow & & Inflow & Outflow \\
\hline May - September & 528 & 486 & & 189 & 32 \\
October - April & 479 & 162 & & 54.6 & 8.6 \\
\cline { 2 - 3 } \cline { 5 - 6 } Total & 1,007 & 648 & & 243.6 & 40.6 \\
\hline
\end{tabular}

growth-limiting variables for phytoplankton (Goldman and Horne, 1983; Wetzel, 1983; Ryding and Rast, 1989). Dissolved-orthophosphate concentrations and the sum of dissolved ammonia and dissolved nitriteplus-nitrate concentrations for water samples collected near the surface of Pueblo Reservoir in 1987 and 1989 were evaluated to determine if phosphorus or nitrogen concentrations limited phytoplankton growth in the reservoir. Absolute concentrations of biologically available nitrogen and phosphorus were first reviewed to determine if either nutrient had been depleted to algal growth-limiting levels. If the sum of dissolved nitrite-plus-nitrate and dissolved ammonia as nitrogen is less than $0.020 \mathrm{mg} / \mathrm{L}$, then nitrogen is likely to be a limiting nutrient. If dissolved-orthophosphate concentrations are less than about $0.010 \mathrm{mg} / \mathrm{L}$, then phosphorus is likely to be a limiting nutrient (Ryding and Rast, 1989). After reviewing the absolute concentrations of biologically available nutrients, mass ratios of the biologically available concentrations (N:P) were evaluated.

Based on analysis of the phosphorus and nitrogen content of plankton cells, Redfield and others (1963) determined that, on average, phytoplankton utilize these nutrients in a mass ratio of $7.2 \mathrm{~N}: 1 \mathrm{P}$. If the ratio of the biologically available nitrogen and phosphorus (N:P) in the waterbody is less than about 7.2, nitrogen is a potentially limiting nutrient; if $\mathrm{N}: \mathrm{P}$ is greater than about 7.2, phosphorus is a potentially limiting nutrient. If $\mathrm{N}: \mathrm{P}$ is about 7.2 , then both nutrients or some other factor may be limiting phytoplankton growth. Biologically available nitrogen is the sum of dissolved ammonia, nitrite, and nitrate, while biologically available phosphorus is dissolved orthophosphorus. Although N:P may vary between species, it generally is agreed upon that a mass ratio of biologically available nutrients of about 7-8N:1P is a "reason- 
able approximate boundary for defining the potential limiting nutrient" (Ryding and Rast, 1989).

None of the water samples collected in 1987 and 1989 at sampling sites 3B, 5C, and 7B had cumulative concentrations of dissolved ammonia and dissolved nitrite plus nitrate less than the growth-limiting level for phytoplankton, $0.020 \mathrm{mg} / \mathrm{L}$ (table 6 ). Thirty-six percent of the samples for site $3 \mathrm{~B}, 73$ percent of the samples at site $5 \mathrm{C}$, and 64 percent of the samples at site 7B had dissolved-orthophosphate concentrations less than or equal to the growth-limiting levels for phytoplankton, $0.010 \mathrm{mg} / \mathrm{L}$ (table 6 ). Values for $\mathrm{N}: \mathrm{P}$ ranged from 2 to 146 for the 32 samples collected (table 6). Several N:P values are reported greater than the reported value because the orthophosphate concentrations were reported as less than the level of detection. At site 3B, 8 of the 11 samples collected had N:P values greater than 8 , the level at which phosphorus may be a limiting nutrient to phytoplankton growth. All 11 samples collected for site 5C had N:P values larger than 8 . At site 7B, 9 of the 10 samples collected had N:P values larger than 8 . The large percentage of phosphorus concentrations less than the growthlimiting level and the large percentage of N:P values greater than 8 indicate that phosphorus concentrations in Pueblo Reservoir commonly are present at levels that may potentially limit phytoplankton growth. In the samples collected, nitrogen concentrations do not seem to be potentially limiting for phytoplankton growth.

\section{Trace Elements}

Trace elements occur in relatively small concentrations (commonly less than $1 \mathrm{mg} / \mathrm{L}$ ). Trace-element concentrations were analyzed from water samples collected near the reservoir surface and near the reservoir bottom. Concentrations of trace elements in Pueblo Reservoir can be affected by concentrations entering the reservoir from the Arkansas River, by settling of suspended sediment from the water column, by mobilization of trace elements from the bottom sediments, and by biologically mediated reactions. Additionally, Goldman and Horne (1983) reported that the absolute and biologically available quantities of many trace elements are subject to spatial and temporal variations as a result of variations in the physiochemical environment of the water column.

A statistical summary of total-recoverable and dissolved trace-element concentrations in Pueblo Res-

Table 6. Concentrations of biologically available nitrogen and phosphorus and N:P values for Pueblo Reservoir, 1987 and 1989

[N, dissolved-inorganic nitrogen; $\mathrm{P}$, dissolved orthophosphorus; N:P, mass ratio of dissolved-inorganic nitrogen and dissolved orthophosphorus; $\mathrm{mg} / \mathrm{L}$, milligrams per liter; <, less than; >, greater than; --, missing data]

\begin{tabular}{|c|c|c|c|c|c|c|c|c|c|}
\hline \multirow{3}{*}{$\begin{array}{l}\text { Sample } \\
\text { period }\end{array}$} & \multicolumn{9}{|c|}{ Sampling site ${ }^{1}$} \\
\hline & \multicolumn{3}{|c|}{ 3B } & \multicolumn{3}{|c|}{$5 \mathrm{C}$} & \multicolumn{3}{|c|}{$7 B$} \\
\hline & $\begin{array}{c}N \\
(m g / L)\end{array}$ & $\underset{(m g / L)}{P}$ & N:P & $\underset{(m g /)}{N}$ & $\begin{array}{c}P \\
(m g / L)\end{array}$ & N:P & $\underset{(m g / L)}{N}$ & $\underset{(m g / L)}{P}$ & $\mathbf{N}: \mathbf{P}$ \\
\hline \multicolumn{10}{|c|}{1987} \\
\hline April & 0.35 & 0.019 & 18 & 0.25 & 0.009 & 28 & -- & 0.006 & -- \\
\hline May & .21 & .024 & 8.6 & .034 & $<.001$ & $>34$ & 0.058 & $<.001$ & $>58$ \\
\hline June & .079 & .009 & 8.8 & .032 & $<.001$ & $>32$ & .076 & $<.001$ & $>76$ \\
\hline July & .11 & .017 & 6.6 & .050 & $<.001$ & $>50$ & .034 & .017 & 2.0 \\
\hline August & .059 & $<.001$ & $>59$ & .034 & $<.001$ & $>34$ & .033 & $<.001$ & $>33$ \\
\hline September & .021 & $<.001$ & $>21$ & .041 & $<.001$ & $>41$ & .045 & $<.001$ & $>45$ \\
\hline October & .070 & $<.001$ & $>70$ & .38 & .013 & 29 & .10 & .001 & 102 \\
\hline \multicolumn{10}{|c|}{1989} \\
\hline May & .096 & .025 & 3.8 & .17 & .016 & 11 & .22 & .018 & 12 \\
\hline June & .15 & .013 & 12 & .15 & .001 & 146 & .15 & .012 & 13 \\
\hline August & .20 & .020 & 10 & .064 & .005 & 13 & .17 & .005 & 33 \\
\hline September & .070 & .021 & 3.3 & .15 & .016 & 9.4 & .32 & .014 & 23 \\
\hline
\end{tabular}


ervoir at sampling sites 3B, 5C, and 7B is listed in table 7. The trace elements that occurred in the largest concentrations are barium, iron, manganese, and zinc. A comparison of total-recoverable and dissolved concentrations of these predominant trace elements indicates that less than 50 percent of the iron, manganese, and zinc concentrations are dissolved, which indicates that a large percentage of the predominant trace elements in Pueblo Reservoir are sorbed to suspended sediment that is transported into the reservoir by the Arkansas River. The concentrations of total iron, manganese, and zinc are subject to substantial decreases within the reservoir as the suspended sediment settles from the water column. Most of the iron, manganese, and zinc transported into the reservoir settles out of the water column by transect 4 (fig. 14). Between the upstream and downstream parts of the reservoir, the concentrations of total iron, manganese, and zinc decrease by more than 50 percent. More than 80 percent of the total barium concentration and generally more than 50 percent of the total concentration of the less prevalent trace elements are dissolved; therefore, their concentrations are less subject to decreases because of the settling of suspended sediment. Concentrations of the other trace elements generally do not vary substantially between the upstream and downstream parts of the reservoir (table 7).

Concentrations of many trace elements vary seasonally and spatially in Pueblo Reservoir (table 8). Concentrations of iron, manganese, and zinc in the Arkansas River inflow vary proportionally with suspended-sediment concentrations (Horowitz and others, 1992). Suspended-sediment concentrations are largest in the Arkansas River from mid- to late April through August, during periods of runoff associated with snowmelt or intense summer thunderstorms; thus, the largest concentrations of iron, manganese, and zinc enter the reservoir during this period. The smallest concentrations of iron, manganese, and zinc in the Arkansas River inflow generally occur with the smallest streamflows during September through March. Barium and other trace elements, which occur predominantly in the dissolved form, exhibit much less sensitivity to seasonal relations involving streamflow and sediment concentrations (table 8 ). Settling of suspended sediment and underflow of the Arkansas River results in larger total concentrations of the major trace elements near the reservoir bottom than near the surface during the summer and winter (table 8). Concentrations of dissolved trace elements also are affected to some degree by flow patterns of the Arkansas River within the reservoir. Underflow with large concentrations of dissolved trace elements may contribute to larger trace-element concentrations near the reservoir bottom than near the surface.

Releases of some trace elements from bottom sediments can contribute substantially to trace-element concentrations in the overlying hypolimnion. Relatively large concentrations of dissolved manganese occurred during the summer and fall near the reservoir bottom in the downstream part of the reservoir (transects 6 and 7). During August 1987 and September 1988, dissolved-manganese concentrations near the reservoir bottom at transect 7 were 590 and $530 \mu \mathrm{g} / \mathrm{L}$, respectively. Dissolved-oxygen concentrations were virtually depleted during both periods. The concentration increases seem to be caused by releases from the bottom sediments. The increases in manganese concentrations were substantially larger than the increases in iron concentrations, because manganese is reduced and mobilized at a higher redox potential than iron (Wetzel, 1983). Prolonged and severe anoxic conditions would be expected to result in large releases of iron and manganese from the bottom sediments. Releases of manganese from the bottom sediments diminish after fall turnover mixes the deepest waters of the reservoir with well-oxygenated water from near the surface. Turnover typically is complete by mid- to late October.

Flux rates for iron and manganese were estimated from reservoir bottom-sediment samples collected in 1987 and 1988. As with the previously discussed flux of nutrients from bottom sediments, iron and manganese flux rates were calculated with the equation for Fick's first law (Thibodeaux, 1979). The interstitial pore water of the sediment samples was analyzed for dissolved manganese and iron. In the five samples collected, dissolved-iron concentrations in the upper $1 \mathrm{~cm}$ of the bottom sediments ranged from 2,100 to $7,500 \mu \mathrm{g} / \mathrm{L}$, and the average was $4,500 \mu \mathrm{g} / \mathrm{L}$.

Dissolved-iron concentrations below $1 \mathrm{~cm}$ in the bottom sediments generally were much larger but highly variable. Dissolved-iron concentrations in the overlying hypolimnion averaged about $10 \mu \mathrm{g} / \mathrm{L}$, which indicates that a strong gradient exists for iron flux from the bottom sediments to the water column. The average iron flux rate for the five samples collected was calculated to be about $18,700 \mu \mathrm{g} / \mathrm{m}^{2} /$ day. Manganese concentrations in the upper $1 \mathrm{~cm}$ of the five bottomsediment samples collected ranged from 20 to $9,000 \mu \mathrm{g} / \mathrm{L}$, and the average concentration was $3,600 \mu \mathrm{g} / \mathrm{L}$. As with iron, manganese concentrations below the $1-\mathrm{cm}$ level in the bottom sediments were larger but highly variable. The average manganese concentration in the overlying hypolimnion was about $120 \mu \mathrm{g} / \mathrm{L}$. The average calculated flux rate of manga- 
Table 7. Statistical summary of total-recoverable and dissolved trace-element concentrations in Pueblo Reservoir, 1986 through 1989

$[\mu \mathrm{g} / \mathrm{L}$, micrograms per liter; --, insufficient data to calculate statistic]

\begin{tabular}{|c|c|c|c|c|c|c|}
\hline Constituent & $\begin{array}{l}\text { Sampling } \\
\text { site }^{1}\end{array}$ & $\begin{array}{c}\text { Number of } \\
\text { analyses }\end{array}$ & $\begin{array}{c}\text { Number of } \\
\text { analyses less } \\
\text { than detection } \\
\text { level }\end{array}$ & $\begin{array}{l}\text { Twenty- } \\
\text { fifth } \\
\text { percentile }\end{array}$ & Median & $\begin{array}{c}\text { Seventy- } \\
\text { fifth } \\
\text { percentile }\end{array}$ \\
\hline \multirow[t]{3}{*}{ Arsenic, dissolved $(\mu \mathrm{g} / \mathrm{L})$} & 3B & 44 & 32 & 0.34 & 0.59 & 1 \\
\hline & $5 \mathrm{C}$ & 43 & 32 & .29 & .54 & 1 \\
\hline & $7 \mathrm{~B}$ & 41 & 31 & .26 & .50 & .97 \\
\hline \multirow[t]{3}{*}{ Arsenic, total $(\mu \mathrm{g} / \mathrm{L})$} & 3B & 44 & 20 & .60 & 1 & 2 \\
\hline & $5 \mathrm{C}$ & 44 & 32 & .26 & .53 & 1 \\
\hline & $7 \mathrm{~B}$ & 42 & 24 & .53 & .85 & 1.3 \\
\hline \multirow[t]{3}{*}{ Barium, dissolved $(\mu \mathrm{g} / \mathrm{L})$} & 3B & 46 & 0 & 54 & 66 & 77 \\
\hline & $5 \mathrm{C}$ & 44 & 0 & 49 & 61 & 76 \\
\hline & $7 \mathrm{~B}$ & 42 & 0 & 50 & 60 & 76 \\
\hline \multirow[t]{3}{*}{ Barium, total recoverable $(\mu \mathrm{g} / \mathrm{L})$} & 3B & 45 & 0 & 70 & 80 & 100 \\
\hline & $5 \mathrm{C}$ & 45 & 0 & 60 & 70 & 80 \\
\hline & 7B & 42 & 0 & 60 & 75 & 90 \\
\hline \multirow[t]{3}{*}{ Cadmium, dissolved $(\mu \mathrm{g} / \mathrm{L})^{3}$} & 3B & 46 & 27 & .18 & .41 & 1 \\
\hline & $5 \mathrm{C}$ & 46 & 27 & .29 & .59 & 1.3 \\
\hline & $7 \mathrm{~B}$ & 44 & 24 & .19 & .47 & 1.8 \\
\hline \multirow[t]{3}{*}{ Cadmium, total recoverable $(\mu \mathrm{g} / \mathrm{L})$} & $3 \mathbf{B}$ & 46 & 46 & -- & -- & -- \\
\hline & $5 \mathrm{C}$ & 46 & 46 & -- & -- & -- \\
\hline & $7 \mathrm{~B}$ & 44 & 44 & -- & -- & -- \\
\hline \multirow[t]{3}{*}{ Chromium, dissolved $(\mu \mathrm{g} / \mathrm{L})$} & $3 B$ & 46 & 26 & .53 & .87 & 2 \\
\hline & $5 \mathrm{C}$ & 46 & 26 & .44 & .85 & 2 \\
\hline & 7B & 44 & 22 & .52 & .91 & 1.8 \\
\hline \multirow[t]{3}{*}{ Chromium, total recoverable $(\mu \mathrm{g} / \mathrm{L})$} & 3B & 46 & 7 & 1.5 & 2.7 & 5.0 \\
\hline & $5 \mathrm{C}$ & 46 & 12 & .99 & 1.7 & 2.8 \\
\hline & $7 \mathrm{~B}$ & 44 & 13 & 1 & 1.7 & 2.7 \\
\hline \multirow[t]{3}{*}{ Copper, dissolved $(\mu \mathrm{g} / \mathrm{L})$} & 3B & 46 & 4 & 1.8 & 2 & 3 \\
\hline & $5 \mathrm{C}$ & 45 & 6 & 2 & 2 & 3 \\
\hline & $7 \mathrm{~B}$ & 43 & 4 & 1 & 2 & 3 \\
\hline \multirow[t]{3}{*}{ Copper, total recoverable $(\mu \mathrm{g} / \mathrm{L})$} & 3B & 46 & 29 & 3.5 & 5.6 & 9.1 \\
\hline & $5 \mathrm{C}$ & 46 & 28 & 3 & 5.3 & 9.1 \\
\hline & $7 B$ & 44 & 28 & 2.5 & 4.3 & 7.3 \\
\hline
\end{tabular}


Table 7. Statistical summary of total-recoverable and dissolved trace-element concentrations in Pueblo Reservoir, 1986 through 1989 --Continued

\begin{tabular}{|c|c|c|c|c|c|c|}
\hline Constituent & $\begin{array}{l}\text { Sampling } \\
\text { site }^{1}\end{array}$ & $\begin{array}{c}\text { Number of } \\
\text { analyses }\end{array}$ & $\begin{array}{c}\text { Number of } \\
\text { analyses less } \\
\text { than detection } \\
\text { level }{ }^{2}\end{array}$ & $\begin{array}{l}\text { Twenty- } \\
\text { fifth } \\
\text { percentile }\end{array}$ & Median & $\begin{array}{l}\text { Seventy- } \\
\text { fifth } \\
\text { percentile }\end{array}$ \\
\hline \multirow[t]{3}{*}{ Iron, dissolved $(\mu \mathrm{g} / \mathrm{L})$} & $3 \mathbf{B}$ & 46 & 0 & 9.5 & 20 & 32 \\
\hline & $5 \mathrm{C}$ & 46 & 2 & 9 & 20 & 31 \\
\hline & 7B & 44 & 0 & 9.3 & 15 & 25 \\
\hline \multirow[t]{3}{*}{ Iron, total recoverable $(\mu \mathrm{g} / \mathrm{L})$} & $3 B$ & 46 & 0 & 147 & 330 & 1050 \\
\hline & $5 C$ & 45 & 0 & 75 & 120 & 170 \\
\hline & $7 B$ & 44 & 0 & 60 & 95 & 150 \\
\hline \multirow[t]{3}{*}{ Lead, dissolved $(\mu \mathrm{g} / \mathrm{L})$} & 3B & 46 & 29 & 0.37 & 0.71 & 1.3 \\
\hline & $5 C$ & 48 & 32 & .29 & .64 & 2 \\
\hline & $7 \mathbf{B}$ & 44 & 21 & .59 & 1.5 & 2 \\
\hline \multirow[t]{3}{*}{ Lead, total recoverable $(\mu \mathrm{g} / \mathrm{L})$} & 3B & 46 & 35 & 1.8 & 2.7 & 4.2 \\
\hline & $5 C$ & 46 & 34 & 1.6 & 2.4 & 3.4 \\
\hline & $7 \mathrm{~B}$ & 44 & 34 & 1.6 & 2.2 & 2.9 \\
\hline \multirow[t]{3}{*}{ Manganese, dissolved $(\mu \mathrm{g} / \mathrm{L})$} & $3 B$ & 46 & 1 & 6.5 & 27 & 59 \\
\hline & $5 \mathrm{C}$ & 46 & 2 & 2.8 & 9 & 18 \\
\hline & $7 \mathrm{~B}$ & 44 & 2 & 3 & 7 & 37 \\
\hline \multirow[t]{3}{*}{ Manganese, total recoverable ( $\mu \mathrm{g} / \mathrm{L})$} & 3B & 46 & 0 & 24 & 73 & 123 \\
\hline & $5 C$ & 46 & 0 & 12 & 26 & 55 \\
\hline & $7 B$ & 44 & 0 & 8.7 & 26 & 118 \\
\hline \multirow[t]{3}{*}{ Mercury, dissolved $(\mu \mathrm{g} / \mathrm{L})$} & $3 B$ & 10 & 10 & -- & $\cdots$ & -- \\
\hline & $5 \mathrm{C}$ & 10 & 10 & - & -- & -- \\
\hline & $7 \mathrm{~B}$ & 10 & 10 & -- & -- & -- \\
\hline \multirow[t]{3}{*}{ Mercury, total recoverable $(\mu \mathrm{g} / \mathrm{L})$} & 3B & 10 & 9 & $\cdots$ & -- & -- \\
\hline & $5 \mathrm{C}$ & 10 & 10 & -- & -- & -. \\
\hline & $7 B$ & 10 & 9 & - & -- & -- \\
\hline \multirow[t]{3}{*}{ Molybdenum, dissolved $(\mu \mathrm{g} / \mathrm{L})$} & $3 \mathbf{B}$ & 46 & 0 & 6 & 7.5 & 11 \\
\hline & $5 \mathrm{C}$ & 45 & 0 & 7 & 8 & 10 \\
\hline & $7 B$ & 43 & 0 & 7 & 8 & 11 \\
\hline \multirow[t]{3}{*}{ Molybdenum, total recoverable $(\mu \mathrm{g} / \mathrm{L})$} & $3 B$ & 46 & 0 & 7 & 9.5 & 13 \\
\hline & $5 \mathrm{C}$ & 46 & 0 & 6.8 & 8.5 & 11 \\
\hline & 7B & 44 & 0 & 7 & 9.5 & 11 \\
\hline
\end{tabular}


Tabie 7. Statistical summary of total-recoverable and dissolved trace-element concentrations in Pueblo Reservoir, 1986 through 1989 --Continued

\begin{tabular}{|c|c|c|c|c|c|c|}
\hline Constituent & $\begin{array}{l}\text { Sampiling } \\
\text { site }^{1}\end{array}$ & $\begin{array}{l}\text { Number of } \\
\text { analyses }\end{array}$ & $\begin{array}{c}\text { Number of } \\
\text { analyses iess } \\
\text { than detection } \\
\text { lovel }\end{array}$ & $\begin{array}{l}\text { Twenty- } \\
\text { fifth } \\
\text { percentile }\end{array}$ & Median & $\begin{array}{l}\text { Seventy- } \\
\text { fifth } \\
\text { percentile }\end{array}$ \\
\hline \multirow[t]{3}{*}{ Nickel, dissolved $(\mu \mathrm{g} / \mathrm{L})$} & $3 B$ & 46 & 1 & 3 & 6 & 8.3 \\
\hline & $5 C$ & 45 & 2 & 4 & 5 & 8.8 \\
\hline & $7 \mathrm{~B}$ & 42 & 4 & 3 & 5.5 & 8 \\
\hline \multirow[t]{3}{*}{ Nickel, total recoverable $(\mu \mathrm{g} / \mathrm{L})$} & 3B & 46 & 19 & 6 & 9.3 & 15 \\
\hline & $5 C$ & 46 & 20 & 5.6 & 8 & 11 \\
\hline & 7B & 46 & 23 & 6.1 & 8 & 10 \\
\hline \multirow[t]{3}{*}{ Slenium, dissolved $(\mu \mathrm{g} / \mathrm{L})$} & $3 \mathrm{~B}$ & 47 & $\mathbf{0}$ & 1 & 2 & 3 \\
\hline & $5 \mathrm{C}$ & 44 & $\mathbf{0}$ & 2 & 2 & 3 \\
\hline & 7B & 43 & 0 & 2 & 3 & 4 \\
\hline \multirow[t]{3}{*}{ Selenium, total $(\mu \mathrm{g} / \mathrm{L})$} & $3 B$ & 44 & 1 & 2 & 2 & 3 \\
\hline & $5 C$ & 46 & 0 & 2 & 2 & 3 \\
\hline & 7B & 44 & 0 & 2 & 3 & 3 \\
\hline \multirow[t]{3}{*}{ Silver, dissolved $(\mu \mathrm{g} / \mathrm{L})$} & 3B & 46 & 38 & 0.19 & 0.35 & 0.65 \\
\hline & $5 \mathrm{C}$ & 46 & 34 & .25 & .45 & .79 \\
\hline & 7B & 44 & 34 & .25 & .43 & .73 \\
\hline \multirow[t]{3}{*}{ Silver, total recoverable $(\mu \mathrm{g} / \mathrm{L})$} & 3B & 46 & 46 & -- & -- & -- \\
\hline & $5 \mathrm{C}$ & 46 & 46 & -- & -- & -- \\
\hline & 7B & 44 & 44 & -- & -- & -- \\
\hline \multirow[t]{3}{*}{ Zinc, dissolved $(\mu \mathrm{g} / \mathrm{L})$} & 3B & 46 & 21 & 1.5 & 3.2 & 6.7 \\
\hline & $5 \mathrm{C}$ & 46 & 24 & 1.5 & 3.2 & 6.8 \\
\hline & 7B & 44 & 22 & 1.2 & 2.8 & 6.9 \\
\hline \multirow[t]{3}{*}{ Zinc, total recoverable $(\mu g / L)$} & 3B & 46 & 6 & 10 & 20 & 30 \\
\hline & $5 \mathrm{C}$ & 44 & 18 & 5.2 & 8.7 & 10 \\
\hline & 7B & 44 & 17 & 6.5 & 9.3 & 10 \\
\hline
\end{tabular}

'Sampling site location shown in plate 1.

${ }^{2}$ If the constituent contained one or more measurements less than the detection level, then the statistic was estimated using the maximum likelihood method of Helsel and Cohn (1988). If more than 85 percent of the measurements for a constituent were less than the detection level, the statistic could not be computed.

${ }^{3}$ The concentrations of dissolved cadmium, lead, and silver reported greater than the analytical detection level have been regarded as questionable by the Colorado Department of Health (written commun., 1989) because of comparison of these data to data analyzed by the Colorado Division of Wildlife from samples collected from the Arkansas River upstream from Pueblo Reservoir. 

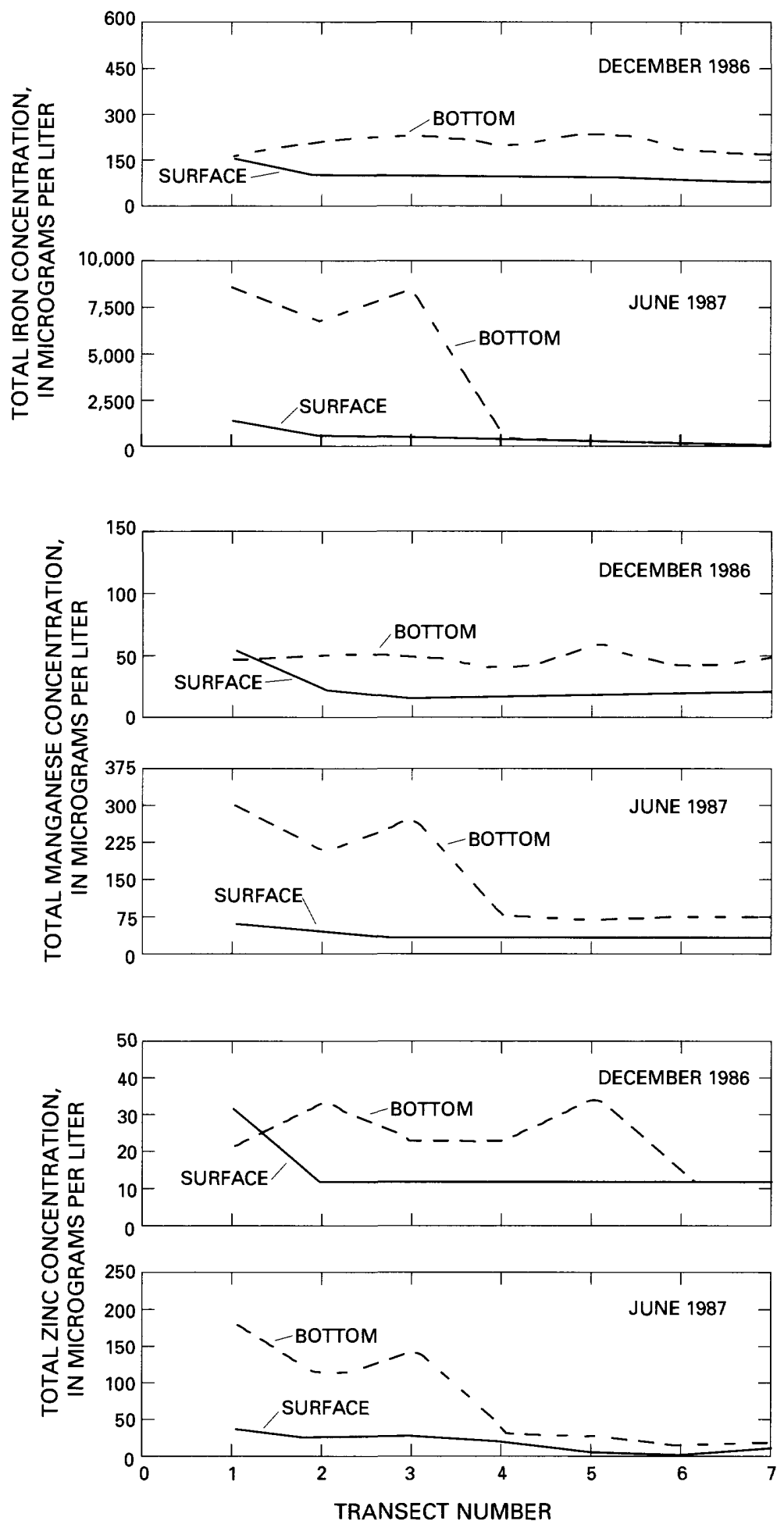

Figure 14. Spatial and temporal variations in concentrations of totalrecoverable iron, manganese, and zinc in Pueblo Reservoir, December 1986 and June 1987. 
Table 8. A comparison of seasonal and spatial differences in trace-element concentrations in Pueblo Reservoir, 1986 through 1989

[ $\mu \mathrm{g} / \mathrm{L}$, micrograms per liter; Spring-Summer, samples collected April through August; Fall-Winter, samples collected September through March; <, less than; $\cdots$, insufficient data to calculate statistic]

\begin{tabular}{|c|c|c|c|}
\hline \multirow{2}{*}{ Constituent } & \multirow{2}{*}{ Sampling site ${ }^{1}$} & \multicolumn{2}{|c|}{ Medlan concentration ${ }^{2}$} \\
\hline & & Near reservolr surface & Near reservoir bottom \\
\hline \multicolumn{4}{|c|}{ Spring-Summer } \\
\hline \multirow[t]{3}{*}{ Arsenic, dissolved $(\mu \mathrm{g} / \mathrm{L})$} & 3B & 0.12 & 0.71 \\
\hline & $5 \mathrm{C}$ & .60 & .60 \\
\hline & 7B & .39 & .39 \\
\hline \multicolumn{4}{|c|}{ Fall-Winter } \\
\hline & 3B & $<1$ & $<1$ \\
\hline & $5 \mathrm{C}$ & $<1$ & $<1$ \\
\hline & $7 \mathrm{~B}$ & $<1$ & $<1$ \\
\hline \multicolumn{4}{|c|}{ Spring-Summer } \\
\hline \multirow[t]{3}{*}{ Arsenic, total $(\mu \mathrm{g} / \mathrm{L})$} & 3B & .94 & 1.5 \\
\hline & $5 \mathrm{C}$ & .56 & .73 \\
\hline & $7 \mathrm{~B}$ & .56 & .74 \\
\hline \multicolumn{4}{|c|}{ Fall-Winter } \\
\hline & $3 B$ & $<1$ & 1.5 \\
\hline & $5 C$ & $<1$ & $<1$ \\
\hline & $7 \mathrm{~B}$ & 1 & 1.0 \\
\hline \multicolumn{4}{|c|}{ Spring-Summer } \\
\hline \multirow[t]{3}{*}{ Barium, dissolved $(\mu \mathrm{g} / \mathrm{L})$} & 3B & 51 & 66 \\
\hline & $5 \mathrm{C}$ & 52 & 60 \\
\hline & 7B & 54 & 58 \\
\hline \multicolumn{4}{|c|}{ Fall-Winter } \\
\hline & 3B & 75 & 77 \\
\hline & $5 \mathrm{C}$ & 70 & 72 \\
\hline & 7B & 64 & 66 \\
\hline \multicolumn{4}{|c|}{ Spring-Summer } \\
\hline \multirow[t]{3}{*}{ Barium, total recoverable $(\mu \mathrm{g} / \mathrm{L})$} & 3B & 70 & 95 \\
\hline & $5 \mathrm{C}$ & 60 & 80 \\
\hline & 7B & 70 & 75 \\
\hline \multicolumn{4}{|c|}{ Fall-Winter } \\
\hline & 3B & 80 & 100 \\
\hline & $5 \mathrm{C}$ & 70 & 75 \\
\hline & $7 \mathrm{~B}$ & 80 & 90 \\
\hline \multicolumn{4}{|c|}{ Spring-Summer } \\
\hline \multirow[t]{7}{*}{ Chromium, dissolved $(\mu \mathrm{g} / \mathrm{L})$} & $3 B$ & .80 & .70 \\
\hline & $5 \mathrm{C}$ & .86 & .78 \\
\hline & 7B & .91 & 1.0 \\
\hline & \multicolumn{2}{|c|}{ Fall-Winter } & \\
\hline & 3B & .98 & 1.0 \\
\hline & $5 C$ & .97 & .97 \\
\hline & 7B & 1.0 & .60 \\
\hline
\end{tabular}


Table 8. A comparison of seasonal and spatial differences in trace-element concentrations in Pueblo Reservoir, 1986 through 1989 --Continued

\begin{tabular}{|c|c|c|c|}
\hline \multirow{2}{*}{ Constituent } & \multirow{2}{*}{ Sampllng site ${ }^{1}$} & \multicolumn{2}{|c|}{ Medlan concentration ${ }^{2}$} \\
\hline & & Near reservolr surface & Near reservoir bottom \\
\hline \multicolumn{4}{|c|}{ Spring-Summer } \\
\hline \multirow[t]{7}{*}{ Chromium, total recoverable $(\mu \mathrm{g} / \mathrm{L})$} & 3B & 2.0 & 4.0 \\
\hline & $5 \mathrm{C}$ & 1.5 & 1.9 \\
\hline & 7B & 1.3 & 1.8 \\
\hline & \multicolumn{2}{|c|}{ Fall-Winter } & \\
\hline & 3B & 2.0 & 3.0 \\
\hline & $5 \mathrm{C}$ & 1.0 & 1.0 \\
\hline & $7 \mathrm{~B}$ & 2.0 & 2.0 \\
\hline \multicolumn{4}{|c|}{ Spring-Summer } \\
\hline \multirow[t]{7}{*}{ Copper, dissolved $(\mu \mathrm{g} / \mathrm{L})$} & 3B & 2.5 & 2.0 \\
\hline & $5 \mathrm{C}$ & 2.0 & 2.0 \\
\hline & 7B & 3.0 & 2.0 \\
\hline & \multicolumn{2}{|c|}{ Fall-Winter } & \\
\hline & 3B & 3.0 & 3.0 \\
\hline & $5 \mathrm{C}$ & 3.0 & 2.0 \\
\hline & 7B & 2.0 & 3.0 \\
\hline \multicolumn{4}{|c|}{ Spring-Summer } \\
\hline Copper, total recoverable $(\mu \mathrm{g} / \mathrm{L})$ & 3B & 2.7 & 6.0 \\
\hline & $5 \mathrm{C}$ & 4.0 & 6.0 \\
\hline & 7B & 4.7 & 3.6 \\
\hline \multicolumn{4}{|c|}{ Fall-Winter } \\
\hline & 3B & 3.2 & 6.0 \\
\hline & $5 \mathrm{C}$ & 6.1 & 5.4 \\
\hline & $7 \mathrm{~B}$ & 4.6 & 5.5 \\
\hline \multicolumn{4}{|c|}{ Spring-Summer } \\
\hline \multirow[t]{3}{*}{ Iron, dissolved $(\mu \mathrm{g} / \mathrm{L})$} & $3 \mathrm{~B}$ & 20 & 13 \\
\hline & $5 \mathrm{C}$ & 20 & 25 \\
\hline & $7 \mathrm{~B}$ & 11 & 20 \\
\hline \multicolumn{4}{|c|}{ Fall-Winter } \\
\hline & 3B & 20 & 10 \\
\hline & $5 \mathrm{C}$ & 10 & 10 \\
\hline & $7 \mathrm{~B}$ & 18 & 16 \\
\hline \multicolumn{4}{|c|}{ Spring-Summer } \\
\hline \multirow[t]{7}{*}{ Iron, total recoverable $(\mu \mathrm{g} / \mathrm{L})$} & 3B & 180 & 1,600 \\
\hline & $5 \mathrm{C}$ & 85 & 170 \\
\hline & $7 \mathrm{~B}$ & 70 & 130 \\
\hline & \multicolumn{2}{|c|}{ Fall-Winter } & \\
\hline & 3B & 90 & 530 \\
\hline & $5 \mathrm{C}$ & 75 & 125 \\
\hline & 7B & 70 & 150 \\
\hline
\end{tabular}


Table 8. A comparison of seasonal and spatial differences in trace-element concentrations in Pueblo Reservoir, 1986 through 1989 --Continued

\begin{tabular}{|c|c|c|c|}
\hline \multirow{2}{*}{ Constituent } & \multirow{2}{*}{ Sampling site ${ }^{1}$} & \multicolumn{2}{|c|}{ Median concentration ${ }^{2}$} \\
\hline & & Near reservoir surface & Near reservoir bottom \\
\hline \multicolumn{4}{|c|}{ Spring-Summer } \\
\hline \multirow{7}{*}{ Lead, dissolved $(\mu \mathrm{g} / \mathrm{L})$} & 3B & .75 & .93 \\
\hline & $5 \mathrm{C}$ & .67 & .68 \\
\hline & $7 \mathrm{~B}$ & 1.5 & 1.1 \\
\hline & \multicolumn{2}{|c|}{ Fall-Wimter } & \\
\hline & 3B & .61 & $<1$ \\
\hline & $5 C$ & .65 & .65 \\
\hline & $7 \mathrm{~B}$ & 1.1 & 1.1 \\
\hline \multicolumn{4}{|c|}{ Spring-Summer } \\
\hline \multirow[t]{7}{*}{ Lead, total recoverable $(\mu \mathrm{g} / \mathrm{L})$} & 3B & 2.4 & 3.7 \\
\hline & $5 C$ & 1.7 & 2.6 \\
\hline & $7 \mathrm{~B}$ & -- & 3.1 \\
\hline & \multicolumn{2}{|c|}{ Fall-Winter } & \\
\hline & 3B & $<10$ & $<10$ \\
\hline & $5 \mathrm{C}$ & $<10$ & $<10$ \\
\hline & $7 \mathrm{~B}$ & $<10$ & $<10$ \\
\hline \multicolumn{4}{|c|}{ Spring-Summer } \\
\hline \multirow{3}{*}{ Manganese, dissolved $(\mu \mathrm{g} / \mathrm{L})$} & $3 B$ & 8.0 & 70 \\
\hline & $5 C$ & 3.5 & 32 \\
\hline & $7 \mathrm{~B}$ & 2.5 & 14 \\
\hline \multicolumn{4}{|c|}{ Fall-Winter } \\
\hline & $3 B$ & 9.0 & 44 \\
\hline & $5 C$ & 3.0 & 12 \\
\hline & $7 \mathrm{~B}$ & 2.5 & 95 \\
\hline \multicolumn{4}{|c|}{ Spring-Summer } \\
\hline \multirow[t]{3}{*}{ Manganese, total recoverable $(\mu \mathrm{g} / \mathrm{L})$} & 3B & 32 & 160 \\
\hline & $5 C$ & 14 & 75 \\
\hline & $7 \mathrm{~B}$ & 7.5 & 83 \\
\hline \multicolumn{4}{|c|}{ Fall-Winter } \\
\hline & 3B & 22 & 86 \\
\hline & $5 C$ & 17 & 38 \\
\hline & $7 B$ & 17 & 150 \\
\hline \multicolumn{4}{|c|}{ Spring-Summer } \\
\hline \multirow[t]{7}{*}{ Mercury, dissolved $(\mu \mathrm{g} / \mathrm{L})$} & $3 \mathrm{~B}$ & $<1$ & $<1$ \\
\hline & $5 C$ & $<1$ & $<1$ \\
\hline & $7 \mathrm{~B}$ & $<1$ & $<1$ \\
\hline & \multicolumn{2}{|c|}{ Fall-Winter } & \\
\hline & 3B & $<1$ & $<1$ \\
\hline & $5 C$ & $<1$ & $<1$ \\
\hline & $7 \mathrm{~B}$ & $<1$ & $<1$ \\
\hline
\end{tabular}


Table 8. A comparison of seasonal and spatial differences in trace-element concentrations in Pueblo Reservoir, 1986 through 1989 --Continued

\begin{tabular}{|c|c|c|c|}
\hline \multirow{2}{*}{ Constituent } & \multirow{2}{*}{ Sampling site ${ }^{1}$} & \multicolumn{2}{|c|}{ Median concentration ${ }^{2}$} \\
\hline & & Near reservolr surface & Near reservolr bottom \\
\hline \multicolumn{4}{|c|}{ Spring-Summer } \\
\hline \multirow[t]{7}{*}{ Mercury, total recoverable $(\mu \mathrm{g} / \mathrm{L})$} & 3B & $<1$ & $<1$ \\
\hline & $5 \mathrm{C}$ & $<1$ & $<1$ \\
\hline & 7B & $<1$ & $<1$ \\
\hline & \multicolumn{2}{|c|}{ Fall-Winter } & \\
\hline & 3B & $<1$ & $<1$ \\
\hline & $5 \mathrm{C}$ & $<1$ & $<1$ \\
\hline & $7 \mathrm{~B}$ & $<1$ & $<1$ \\
\hline \multicolumn{4}{|c|}{ Spring-Summer } \\
\hline \multirow[t]{7}{*}{ Molybdenum, dissolved $(\mu \mathrm{g} / \mathrm{L})$} & $3 B$ & 6.0 & 7.0 \\
\hline & $5 \mathrm{C}$ & 7.0 & 6.0 \\
\hline & 7B & 7.0 & 8.0 \\
\hline & \multicolumn{2}{|c|}{ Fall-Winter } & \\
\hline & 3B & 10 & 11 \\
\hline & $5 \mathrm{C}$ & 10 & 11 \\
\hline & $7 \mathrm{~B}$ & 10 & 10 \\
\hline \multicolumn{4}{|c|}{ Spring-Summer } \\
\hline \multirow[t]{7}{*}{ Molybdenum, total recoverable $(\mu \mathrm{g} / \mathrm{L})$} & $3 \mathrm{~B}$ & 7.0 & 11 \\
\hline & $5 C$ & 7.5 & 8.5 \\
\hline & 7B & 8.0 & 11 \\
\hline & \multicolumn{2}{|c|}{ Fall-Winter } & \\
\hline & 3B & 11 & 13 \\
\hline & $5 C$ & 10 & 10 \\
\hline & $7 \mathrm{~B}$ & 9.5 & 11 \\
\hline \multicolumn{4}{|c|}{ Spring-Summer } \\
\hline \multirow[t]{3}{*}{ Nickel, dissolved $(\mu \mathrm{g} / \mathrm{L})$} & $3 B$ & 4.0 & 3.5 \\
\hline & $5 \mathrm{C}$ & 5.0 & 5.0 \\
\hline & $7 \mathrm{~B}$ & 5.0 & 7.0 \\
\hline \multicolumn{4}{|c|}{ Fall-Winter } \\
\hline & 3B & 6.0 & 7.0 \\
\hline & $5 \mathrm{C}$ & 5.0 & 6.0 \\
\hline & $7 \mathrm{~B}$ & 6.5 & 6.0 \\
\hline \multicolumn{4}{|c|}{ Spring-Summer } \\
\hline \multirow[t]{7}{*}{ Nickel, total recoverable $(\mu \mathrm{g} / \mathrm{L})$} & $3 B$ & 6.7 & 13 \\
\hline & $5 \mathrm{C}$ & 7.0 & 8.6 \\
\hline & $7 \mathrm{~B}$ & 7.9 & 8.7 \\
\hline & \multicolumn{2}{|c|}{ Fall-Winter } & \\
\hline & 3B & 9.5 & 13 \\
\hline & $5 \mathrm{C}$ & 8.4 & 10 \\
\hline & 7B & 8.7 & 8.0 \\
\hline
\end{tabular}


Table 8. A comparison of seasonal and spatial differences in trace-element concentrations in Pueblo Reservoir, 1986 through 1989 --Continued

\begin{tabular}{|c|c|c|c|}
\hline \multirow{2}{*}{ Constltuent } & \multirow{2}{*}{ Samplling site ${ }^{1}$} & \multicolumn{2}{|c|}{ Median concentration ${ }^{2}$} \\
\hline & & Near reservoir surface & Near reservoir bottom \\
\hline \multicolumn{4}{|c|}{ Spring-Summer } \\
\hline \multirow[t]{3}{*}{ Selenium, dissolved $(\mu \mathrm{g} / \mathrm{L})$} & 3B & 2.0 & 1.5 \\
\hline & $5 \mathrm{C}$ & 2.0 & 2.0 \\
\hline & $7 \mathrm{~B}$ & 3.0 & 2.0 \\
\hline \multicolumn{4}{|c|}{ Fall-Winter } \\
\hline & 3B & 3.0 & 3.0 \\
\hline & $5 C$ & 3.5 & 3.0 \\
\hline & 7B & 4.0 & 2.5 \\
\hline \multicolumn{4}{|c|}{ Spring-Summer } \\
\hline \multirow[t]{3}{*}{ Selenium, total $(\mu \mathrm{g} / \mathrm{L})$} & $3 B$ & 2.0 & 2.0 \\
\hline & $5 C$ & 2.0 & 2.0 \\
\hline & $7 \mathrm{~B}$ & 2.5 & 3.3 \\
\hline \multicolumn{4}{|c|}{ Fall-Winter } \\
\hline & 3B & 3.0 & 3.0 \\
\hline & $5 C$ & 3.0 & 3.0 \\
\hline & 7B & 3.0 & 2.5 \\
\hline \multicolumn{4}{|c|}{ Spring-Summer } \\
\hline \multirow[t]{3}{*}{ Zinc, dissolved $(\mu \mathrm{g} / \mathrm{L})$} & 3B & 3.0 & 2.6 \\
\hline & $5 C$ & 1.9 & 2.6 \\
\hline & $7 B$ & 1.8 & 4.4 \\
\hline \multicolumn{4}{|c|}{ Fall-Wimter } \\
\hline & 3B & 3.3 & 3.7 \\
\hline & $5 C$ & 4.3 & 3.9 \\
\hline & $7 \mathrm{~B}$ & 1.6 & 3.0 \\
\hline \multicolumn{4}{|c|}{ Spring-Summer } \\
\hline \multirow[t]{7}{*}{ Zinc, total recoverable $(\mu \mathrm{g} / \mathrm{L})$} & 3B & 10 & 40 \\
\hline & $5 C$ & 5.4 & 10 \\
\hline & $7 \mathrm{~B}$ & 8.7 & 10 \\
\hline & \multicolumn{2}{|c|}{ Fall-Wimter } & \\
\hline & 3B & 10 & 30 \\
\hline & $5 C$ & 10 & 10 \\
\hline & 7B & 7.8 & 10 \\
\hline
\end{tabular}

'Sampling site location shown in plate 1.

${ }^{2}$ If the constituent contained one or more measurements less than the detection level, then the statistic was estimated using the maximum likelihood method of Helsel and Cohn (1988). If more than 85 percent of the measurements for a constituent were less than the detection level, the statistic could not be computed. 
nese from the bottom sediments to the water column was about $19,700 \mu \mathrm{g} / \mathrm{m}^{2} /$ day. Because of the small number of bottom-sediment samples collected, the spatial and temporal variation in iron and manganese flux rates could not be evaluated. The estimates for flux rates are based upon samples collected during August and September, when hypolimnetic dissolved-oxygen concentrations were less than $3 \mathrm{mg} / \mathrm{L}$. Flux rates during times of well-oxygenated conditions would be expected to be less than these estimates. Flux rates of iron and manganese may be substantially larger during periods of prolonged dissolved-oxygen depletion in the hypolimnion. As a result, the bottom sediments represent a substantial source of iron and manganese that could be released to the water column under anoxic conditions.

Bottom-sediment cores collected at the central locations of transects 2 through 7 were analyzed for selected trace elements. Data collected from the 0 to 2-cm core depths and the 4 to 6-cm core depths were combined and statistically analyzed. The mean concentrations of the sediments were compared to the upper limit of the 95-percent expected range of traceelement concentrations in soils in the Western United States (Shacklette and Boerngen, 1984) to determine if trace-element concentrations are elevated in the bottom sediments of the reservoir (table 9). Mean mercury $(0.34 \mu \mathrm{g} / \mathrm{g})$ and zinc $(278 \mu \mathrm{g} / \mathrm{g})$ concentrations were larger than their baseline values of $0.25 \mu \mathrm{g} / \mathrm{g}$ and $180 \mu \mathrm{g} / \mathrm{g}$, respectively. Although, the mean lead concentration $(52 \mu \mathrm{g} / \mathrm{g})$ was slightly less than the baseline value $(55 \mu \mathrm{g} / \mathrm{g}), 3$ of the 11 samples had lead concentrations greater than the baseline value. Lead, mercury, and zinc are common constituents of mine drainage and might have been transported to the reservoir from upstream sources and concentrated in the reservoir bottom sediments (Mueller and others, 1991). No other trace elements had elevated concentrations relative to the baseline values. Additionally, Callender and others (1988) reported that sediment cores from Pueblo Reservoir have normalized concentration maxima of cadmium, copper, lead, and zinc at sediment depths that correspond to metal discharges from flooded mine workings that occurred in 1983 and 1985 in the Leadville area (fig. 1) upstream from the reservoir.

Water-quality standards for aquatic life and public water supplies were exceeded for several trace elements during the study. Total-recoverable iron concentrations near the reservoir bottom exceeded the recommended criterion for aquatic life of $1,000 \mu \mathrm{g} / \mathrm{L}$ (U.S. Environmental Protection Agency, 1986) in 11 samples at site 3B and in 1 sample at site $5 \mathrm{C}$ during 1986 through 1989. All samples that exceeded water-
Table 9. Geochemical baselines for selected trace elements in soils in the Western United States and a statistical summary of trace-element concentrations in bottomsediment samples collected from Pueblo Reservoir at transects 2 through 7, October 1987

[Geochemical baselines are based on data from Shacklette and Boerngen, 1984; baseline is the upper limit of the expected 95-percent range; all values in micrograms per gram]

\begin{tabular}{lcccc}
\hline & \multicolumn{4}{c}{ Pueblo Reservoir samples } \\
\cline { 3 - 5 } Element & $\begin{array}{c}\text { Geochem- } \\
\text { icai } \\
\text { baseiine }\end{array}$ & $\begin{array}{c}\text { Num- } \\
\text { ber } \\
\text { of } \\
\text { sam- } \\
\text { pies }\end{array}$ & Mean & $\begin{array}{c}\text { Stand- } \\
\text { ard dovl- } \\
\text { ation }\end{array}$ \\
\hline Barium & 1,700 & 12 & 555 & 70.4 \\
Chromium & 200 & 12 & 61 & 11.4 \\
Copper & 90 & 11 & 35 & 7.5 \\
Iron & 80,000 & 11 & 32,000 & 3,800 \\
Lead & 55 & 11 & 52 & 21 \\
Manganese & 15,000 & 12 & 774 & 223 \\
Mercury & 0.25 & 12 & 0.34 & 0.10 \\
Molybdenum & 4 & 12 & 2.6 & 1.0 \\
Nickel & 66 & 12 & 29 & 4.7 \\
Zinc & 180 & 12 & 278 & 104 \\
\hline
\end{tabular}

quality standards for iron were collected from June through September. The large iron concentrations probably are caused by large concentrations of sediment and iron in the Arkansas River inflow. As previously mentioned in the discussion of turbidity, most sediment and constituents sorbed to sediment, settle from the water column of the reservoir by about transect 4, except when streamflows are relatively large. Streamflows were relatively large at the time of the July 11,1986 , sample at site $5 \mathrm{C}$ that exceeded the total-recoverable iron standard. Because of the welloxygenated conditions that typically are present upstream from transect 5 , it is unlikely that bottomsediment releases contributed to the elevated totalrecoverable iron concentrations.

Dissolved-manganese concentrations near the reservoir bottom exceeded the public water-supply standard of $50 \mu \mathrm{g} / \mathrm{L}$ (Colorado Department of Health, 1990) in 14 samples at site 3B, 3 samples at site 5C, and in 9 samples at site 7B during 1986 through 1989. The large dissolved-manganese concentrations at site 3B seem to be because of large dissolved-manganese concentrations in the Arkansas River inflow during April through mid-September. The large dissolvedmanganese concentrations at sites $5 \mathrm{C}$ and $7 \mathrm{~B}$ probably are caused by low dissolved-oxygen concentrations during the summer and early autumn at the reservoir 
water-sediment interface, which results in the mobilization of dissolved manganese from the bottom sediments.

Several samples analyzed for silver and cadmium exceeded chronic aquatic-life standards (Colorado Department of Health, 1990). Because of the lack of sensitivity of the analytical techniques for these constituents and the large number of analyses that were below the detection level for dissolved cadmium and silver (table 7), the values that exceeded detection levels are suspect. Concentrations of cadmium, lead, and silver reported greater than the analytical detection level have been regarded as questionable by the Colorado Department of Health (written commun., 1989) because of a comparison of these data to data analyzed by the Colorado Division of Wildlife from samples collected from the Arkansas River upstream from Pueblo Reservoir. Concentrations of other trace elements were less than established water-quality standards for Pueblo Reservoir (Colorado Department of Health, 1990).

\section{Total Organic Carbon}

Total organic carbon (TOC) consists of dissolved (DOC) and particulate organic carbon (POC). Thurman (1986) indicates the average TOC concentration for: (1) rivers is about $7 \mathrm{mg} / \mathrm{L}$, (2) oligotrophic lakes is $2.2 \mathrm{mg} / \mathrm{L}$, and (3) eutrophic lakes is $12 \mathrm{mg} / \mathrm{L}$. The majority of organic carbon in lakes is DOC; POC contributes only about 10 percent of the TOC in lakes (Thurman, 1986).

The TOC concentration in reservoirs can be affected by tributary inflows, by algal growth, and by carbon recycling within the reservoir (Thurman, 1986). During 1985 through 1987, TOC concentrations at Arkansas River at Portland (07097000) ranged from 1.3 to $17 \mathrm{mg} / \mathrm{L}$, and the median concentration was $4.0 \mathrm{mg} / \mathrm{L}$. The largest TOC concentrations occurred from April through August following rapid increases in streamflow because of the initial stages of snowmelt runoff in the spring and localized runoff associated with intense summer rainfall. Both types of runoff produce a flushing effect of interstitial soil water that is laden with organic carbon (Thurman, 1986). Organic carbon recycling within the reservoir involves: (1) primary production of algal biomass in the euphotic zone, (2) decomposition of DOC and POC in the water column, (3) settling of POC from the water column to the bottom sediments, and (4) decomposition of POC and DOC in the bottom sediments followed by diffusion of DOC, carbon dioxide, and methane to the overlying hypolimnion. Fall turnover can redistribute organic carbon throughout the water column.
TOC concentrations of water samples collected near the surface and bottom of Pueblo Reservoir from 1985 through 1987 ranged from 1.8 to $9.9 \mathrm{mg} / \mathrm{L}$. Data were divided into two seasons to indicate the seasonal effect of streamflow and primary production of algae. The median concentrations of TOC throughout the reservoir ranged from 3.1 to $4.5 \mathrm{mg} / \mathrm{L}$ during May through September and from 2.5 to $3.5 \mathrm{mg} / \mathrm{L}$ during October through April (fig. 15). Concentrations generally decreased downstream from the reservoir inflow. The decrease probably was caused by settling of POC from the water column. TOC concentrations were larger during May through September than during October through April, probably because: (1) inputs from the Arkansas River are larger during May through September, and (2) primary production is greater in May through September. There was little difference in TOC concentrations in samples collected from near the surface and near the bottom (fig. 15).

\section{Radiochemicals}

Water samples were collected periodically in 1985 through 1987 from Pueblo Reservoir at sites 1B, $3 \mathrm{~B}$, and 7B and analyzed for gross-alpha and grossbeta radioactivity. The gross-alpha analyses are expressed as natural uranium and the gross-beta analyses are expressed as cesium-137 and as strontium-90/ yttrium-90. The gross-alpha and gross-beta analyses are regarded as "a rapid, semiquantitative measure of gross-sample activity” (Thatcher and others, 1977). Gross-alpha radiation is used as a screening device for radium, a naturally occurring radionuclide whose distribution is controlled mainly by the distribution of uranium and thorium (Thatcher and others, 1977). Grossbeta radiation is used as a screening device for manmade radionuclides (U.S. Environmental Protection Agency, 1986). The principal sources of naturally occurring radioactivity in water are the weathering of rocks containing radioactive minerals and the fallout of cosmic-ray-produced nuclides. Nuclear weapons testing is the principal source of most manmade radioactivity in water (Thatcher and others, 1977).

Concentrations of gross-alpha radiation (as natural uranium) are reported as micrograms per liter in table 10 , but drinking water standards for radiochemical constituents are reported in picocuries per liter. Gross-alpha radiation (as natural uranium) is converted from micrograms per liter to picocuries per liter by the conversion factor 0.68 (Thatcher and others, 1977). It is recommended that drinking-water samples with gross-alpha activities greater than $5 \mathrm{pCi} / \mathrm{L}$ should be 


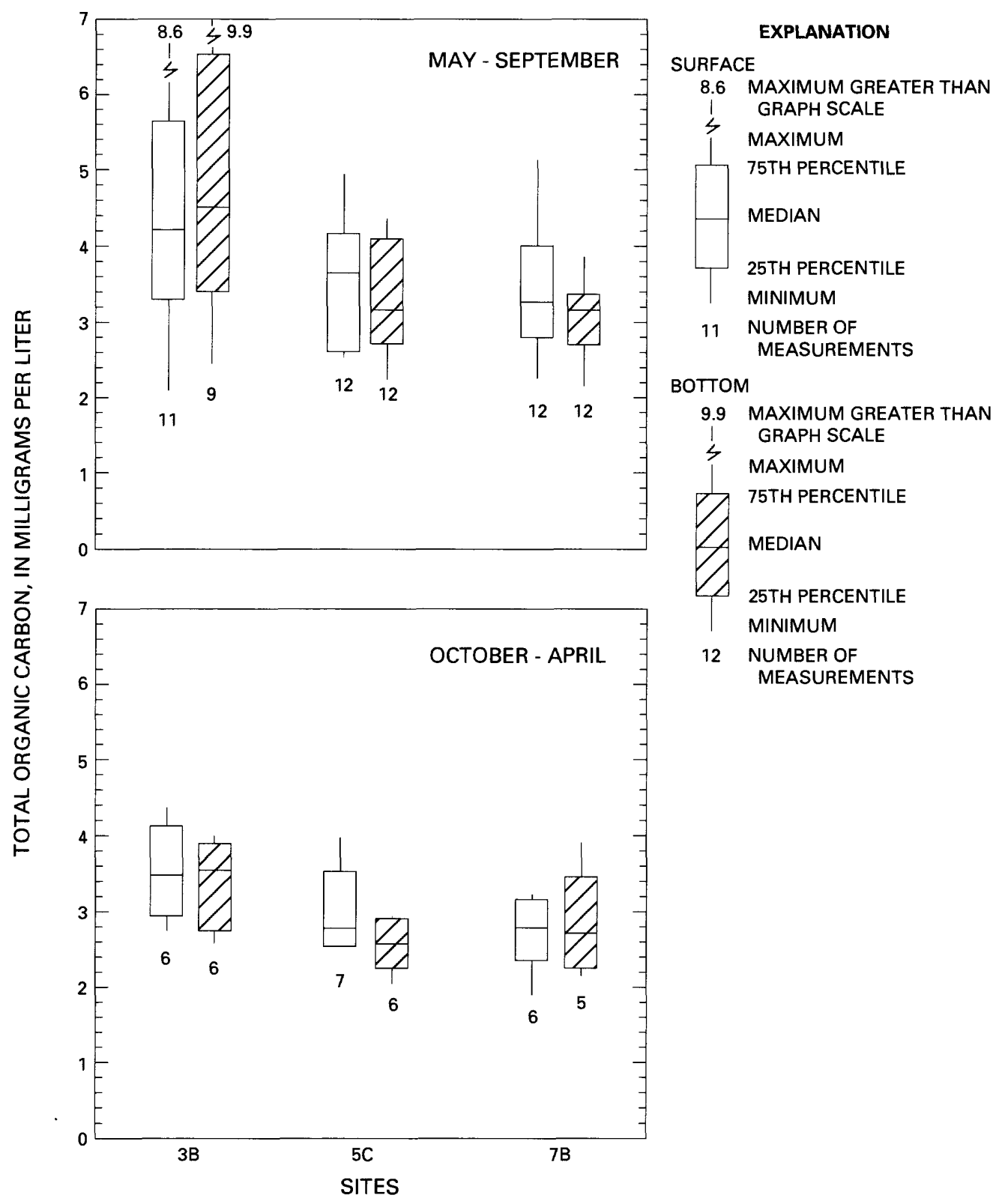

Figure 15. Total-organic-carbon concentrations in Pueblo Reservoir near the reservoir surface and near the reservoir bottom, 1985 through 1987.

analyzed for radium-226 and possibly other radionuclides (U.S. Environmental Protection Agency, 1986). Seven of the 31 samples from sites $1 B, 3 B$, and $7 \mathrm{~B}$ that were analyzed for dissolved gross-alpha radiation exceeded $5 \mathrm{pCi} / \mathrm{L}$; thus, additional sampling and analyses for radium and other radionuclides may be warranted. Six of the seven samples with gross-alpha radiation levels exceeding $5 \mathrm{pCi} / \mathrm{L}$ were collected at site 7B. The median concentration of the gross-alpha radioactivity of the dissolved solids (as natural ura- nium) increased from $3.5 \mathrm{pCi} / \mathrm{L}(5.2 \mu \mathrm{g} / \mathrm{L})$ at site $1 \mathrm{~B}$ to $4.7 \mathrm{pCi} / \mathrm{L}(6.9 \mu \mathrm{g} / \mathrm{L})$ near the reservoir surface and $5.4 \mathrm{pCi} / \mathrm{L}(7.9 \mu \mathrm{g} / \mathrm{L})$ near the reservoir bottom at site 7B (table 10). The median concentration of grossalpha radioactivity of the suspended solids (as natural uranium) decreased from $3.1 \mathrm{pCi} / \mathrm{L}(4.5 \mu \mathrm{g} / \mathrm{L})$ at site $1 \mathrm{~B}$ to less than $0.3 \mathrm{pCi} / \mathrm{L}(0.4 \mu \mathrm{g} / \mathrm{L})$ near the surface at site $7 \mathrm{~B}$ (table 10). The decrease in suspended gross-alpha radiation in the reservoir indicates that 
Table 10. Statistical summary of radiochemical concentrations in Pueblo Reservoir, 1985 through 1987

[U-nat, natural uranium; $\mu \mathrm{g} / \mathrm{L}$, micrograms per liter; <, less than; --, insufficient data to compute statistic; Cs-137, cesium 137; pCi/L, picocuries per liter; Sr/Yt-90, strontium.yttrium 90]

\begin{tabular}{|c|c|c|c|c|c|c|}
\hline Constituent & $\begin{array}{l}\text { Sampling site' } \\
\text { and depth } \\
\text { locale }\end{array}$ & $\begin{array}{c}\text { Number } \\
\text { of } \\
\text { analyses }\end{array}$ & $\begin{array}{c}\text { Number of } \\
\text { analyses less } \\
\text { than detection } \\
\text { level }\end{array}$ & $\begin{array}{l}\text { Twenty- } \\
\text { fifth } \\
\text { percentile }\end{array}$ & Median & $\begin{array}{l}\text { Seventy- } \\
\text { fifth } \\
\text { percentile }\end{array}$ \\
\hline \multirow[t]{5}{*}{ Dissolved gross alpha, as U-nat $(\mu \mathrm{g} / \mathrm{L})$} & 1B near bottom & 5 & 0 & 4.2 & 5.2 & 7.1 \\
\hline & 3B near surface & 6 & 0 & 4.2 & 5.2 & 6.6 \\
\hline & 3B near bottom & 6 & 0 & 4.1 & 4.8 & 5.4 \\
\hline & 7B near surface & 6 & 0 & 4.2 & 6.9 & 9.0 \\
\hline & 7B near bottom & 6 & $\mathbf{0}$ & 4.0 & 7.9 & 9.3 \\
\hline \multirow[t]{5}{*}{ Suspended gross alpha, as U-nat $(\mu \mathrm{g} / \mathrm{L})$} & 1B near bottom & 3 & $\mathbf{0}$ & .8 & 4.5 & 9.2 \\
\hline & 3B near surface & 4 & 3 & $<.4$ & $<.4$ & -- \\
\hline & 3B near bottom & 4 & $\mathbf{0}$ & 1.8 & 4.4 & 9.5 \\
\hline & 7B near surface & 5 & 5 & $<.4$ & $<.4$ & $<.5$ \\
\hline & 7B near bottom & 5 & 3 & -- & - & - \\
\hline \multirow[t]{5}{*}{ Dissolved gross beta, as Cs-137 (pCi/L) } & 1B near bottom & 5 & 0 & 3.6 & 4.7 & 5.2 \\
\hline & 3B near surface & 6 & 0 & 3.2 & 3.5 & 4.1 \\
\hline & 3B near bottom & 6 & 0 & 2.7 & 5.1 & 5.6 \\
\hline & 7B near surface & 6 & 0 & 3.9 & 4.3 & 5.1 \\
\hline & 7B near bottom & 6 & 0 & 3.6 & 4.6 & 5.1 \\
\hline \multirow[t]{5}{*}{ Suspended gross beta, as $\mathrm{Cs}-137(\mathrm{pCi} / \mathrm{L})$} & IB near bottom & 3 & 0 & 1.2 & 4.0 & 6.2 \\
\hline & 3B near surface & 4 & 0 & .43 & .55 & .90 \\
\hline & 3B near bottom & 4 & 0 & 2.7 & 4.2 & 6.4 \\
\hline & 7B near surface & 5 & 3 & $<.4$ & $<.4$ & 6 \\
\hline & 7B near bottom & 5 & 0 & 1.1 & 1.8 & 2.6 \\
\hline \multirow[t]{5}{*}{ Dissolved gross beta, as $\mathrm{Sr} / \mathrm{Y}-90(\mathrm{pCi} / \mathrm{L})$} & 1B near bottom & 5 & 0 & 2.9 & 3.8 & 3.9 \\
\hline & 3B near surface & 6 & 0 & 2.5 & 2.8 & 3.0 \\
\hline & 3B near bottom & 6 & 0 & 2.3 & 4.0 & 4.3 \\
\hline & 7B near surface & 6 & 0 & 2.9 & 3.4 & 4.0 \\
\hline & 7B near bottom & 6 & 0 & 2.7 & 3.6 & 3.9 \\
\hline \multirow[t]{5}{*}{ Suspended gross beta, as $\mathrm{Sr} / \mathrm{Y}-90(\mathrm{pCi} / \mathrm{L})$} & 1B near bottom & 3 & $\mathbf{0}$ & 1.1 & 3.8 & 5.4 \\
\hline & 3B near surface & 4 & 0 & .43 & .55 & .90 \\
\hline & 3B near bottom & 4 & $\mathbf{0}$ & 2.6 & 3.9 & 5.6 \\
\hline & 7B near surface & 5 & 3 & $<.4$ & $<.4$ & .65 \\
\hline & 7B near surface & 5 & 0 & 1.1 & 1.8 & 2.5 \\
\hline
\end{tabular}


practically all the suspended fraction of gross-alpha radiation is removed from the water column because of sedimentation. The potential sources of gross-alpha radiation in the upper Arkansas River Basin and Pueblo Reservoir include the weathering of exposed uranium ore deposits and uranium milling operations in the Canon City area.

The drinking-water standard for gross-beta radiation is $4 \mathrm{mrem} / \mathrm{yr}$ (U.S. Environmental Protection Agency, 1986). The average annual concentration assumed to produce a dose of $4 \mathrm{mrem} / \mathrm{yr}$ is $20,000 \mathrm{pCi} / \mathrm{L}$ of tritium or $8 \mathrm{pCi} / \mathrm{L}$ of strontium- 90 . Additionally, if the gross-beta particle activity is greater than $50 \mathrm{pCi} / \mathrm{L}$, the drinking water should be analyzed to determine which other radionuclides are present (U.S. Environmental Protection Agency, 1986). The maximum gross-beta radiation level analyzed in the Pueblo Reservoir samples was $7.1 \mathrm{pCi} / \mathrm{L}$ as cesium 137, and most samples collected for radiochemical constituents had levels less than this value, which indicates gross-beta radiation in the reservoir is less than the drinking-water standard. The median dissolved gross-beta radiation did not vary much between transects 1 and 7 (table 10). The median suspended gross-beta radiation decreased substantially between transects 1 and 7 because of sedimentation (table 10).

\section{BIOLOGICAL CHARACTERISTICS}

The biological characteristics discussed in this report are chlorophyll $a$ and phytoplankton. The spatial and seasonal variations that occur in chlorophyll $a$ in Pueblo Reservoir are presented. Phytoplankton densities and biovolumes are used to describe the composition of the phytoplankton community, the temporal variations of phytoplankton, the seasonal succession that occurs in the planktonic community, and the phytoplankton that are associated with various waterquality conditions. Phytoplankton density is the number of organisms per unit volume and is used to describe qualitative and semiquantitative differentiation among species. Phytoplankton biovolumes, computed by multiplying the density or number of organisms by their cell volume and are used in addition to phytoplankton density. Biovolume provides a better evaluation of biomass because a great difference in cell size occurs among algae (Wetzel, 1983). The cell volumes used in this report were based on cell volumes available in the literature and generally should approximate the mean cell volume (Chadwick and Assoc., written commun., 1988).

The seasonal and spatial variations in chlorophyll $a$ are described using data collected from 1985 through 1987 at six sites, which included 2 winter samplings, 3 spring samplings, 10 summer samplings, and
5 fall samplings. Phytoplankton data were collected from five sites during 1985 through 1987; additionally,

sites during 1988 and 1989. Seasonal variations in the phytoplankton community are described by using phytoplankton data collected from 1985 through 1987, which included 1 winter sampling, 3 spring samplings, 10 summer samplings, and 5 fall samplings.

Analyses of replicate samples indicate that large variations in phytoplankton densities and biovolumes are the result of errors associated with sample collection, processing, and analyses. Additionally, samples collected concurrently from different depths at the same location in Pueblo Reservoir indicate that the occurrence and abundance of phytoplankton within the reservoir are highly variable over short distances (Edelmann and others, 1991) and that phytoplankton normally are not randomly distributed in the reservoir. Therefore, the subsequent discussions of chlorophyll $a$ and phytoplankton are considered semiquantitative.

\section{Chlorophyll a}

Chlorophyll $a$ is the primary pigment in plants responsible for photosynthesis. Photosynthesis synthesizes organic compounds from water and carbon dioxide by using energy absorbed from sunlight by chlorophyll. Light energy is used to convert carbon dioxide to reduced carbon compounds (Britton and Greeson, 1989). This process can be summarized by

$$
6 \mathrm{CO}_{2}+6 \mathrm{H}_{2} \mathrm{O}+\text { light -..-- }>\mathrm{C}_{6} \mathrm{H}_{12} \mathrm{O}_{6}+6 \mathrm{O}_{2} \text {. }
$$

Therefore, chlorophyll $a$ can be used as a measurement of primary productivity and the quantity of algae present. Because chlorophyll $a$ concentrations can be affected by various environmental and nutritional factors without affecting algal biomass (Britton and Greeson, 1989), chlorophyll $a$ measurements are considered to provide only an approximation of primary productivity and algal biomass. Primary productivity provides an approximation of the rate at which new organic matter and oxygen are produced. Small rates of primary productivity usually are indicative of oligotrophic waters, which contain small nutrient concentrations and a small algal biomass. Large rates of primary productivity usually are indicative of eutrophic waters, which contain large nutrient concentrations and a large algal biomass. Wetzel (1983) provided a general range of chlorophyll $a$ concentrations that were characteristic of lakes of different trophic states. Wetzel (1983) indicated that lakes with chlorophyll $a$ concentrations ranging from 0.3 to $3 \mu \mathrm{g} / \mathrm{L}$ generally have small nutrient concentrations and a small algal bio- 
mass; lakes with chlorophyll $a$ concentrations ranging from 2 to $15 \mu \mathrm{g} / \mathrm{L}$ generally have a moderate biomass; and lakes with chlorophyll $a$ concentrations ranging from 10 to $500 \mu \mathrm{g} / \mathrm{L}$ generally have large nutrient concentrations and a large algal biomass.

Chlorophyll $a$ concentrations measured in the euphotic zone in the upstream (sites $2 B$ and $3 B$ ), middle (sites $4 \mathrm{~B}$ and 5C), and the downstream (sites 6C and 7B) parts of the reservoir are summarized in figure 16. During the winter, chlorophyll $a$ concentrations in the reservoir ranged from 0 to about $6 \mu \mathrm{g} / \mathrm{L}$. The median chlorophyll $a$ concentrations decreased from about $4 \mu \mathrm{g} / \mathrm{L}$ in the upstream part of the reservoir to about $1 \mu \mathrm{g} / \mathrm{L}$ in the downstream part of the reservoir. During the spring, chlorophyll $a$ concentrations in the reservoir ranged from 0 to about $13 \mu \mathrm{g} / \mathrm{L}$. The median chlorophyll $a$ concentrations decreased from about $6 \mu \mathrm{g} / \mathrm{L}$ in the upstream part of the reservoir to about $1.5 \mu \mathrm{g} / \mathrm{L}$ in the downstream part of the reservoir. During the summer, chlorophyll $a$ concentrations in the reservoir ranged from less than 1 to about $93 \mu \mathrm{g} / \mathrm{L}$. The median chlorophyll $a$ concentrations were similar (about $4 \mu \mathrm{g} / \mathrm{L}$ ) throughout the reservoir. During the fall, chlorophyll $a$ concentrations in the reservoir ranged from 1 to about $24 \mu \mathrm{g} / \mathrm{L}$. The median chlorophyll $a$ concentrations decreased from about $9 \mu \mathrm{g} / \mathrm{L}$ in the upstream part of the reservoir to about $2.5 \mu \mathrm{g} / \mathrm{L}$ in the downstream part of the reservoir.

The chlorophyll $a$ data indicate that algal primary productivity and biomass tended to be largest in the upstream part of the reservoir (sites 2B and 3B) during the winter, spring, and fall. However, a statistical analyses of the data indicated there were no statistically significant longitudinal differences $(p=0.05)$ during the winter, spring, or summer. A statistically significant longitudinal difference $(p=0.05)$ was detected during the fall.

\section{Phytoplankton}

Phytoplankton or algae are common and important inhabitants of surface water. Algae usually constitute a substantial source of oxygen in lakes and reservoirs, which is essential for sustaining aquatic life including fish and other organisms. In addition, oxygen is necessary for aerobic decomposition of organic matter that helps to prevent foul or septic conditions that are common when anaerobic decomposition occurs. However, as lakes and reservoirs become increasingly fertile, algal biomass increases and, frequently, nuisance algae, such as algae that produce taste-and-odor problems, become more prolific. Addi- tionally, the decomposition of excessive algal biomass frequently results in substantial oxygen depletion in the hypolimnion during stratification.

An empirical evaluation of phytoplankton densities and biovolumes in Pueblo Reservoir indicated that there were longitudinal variations in the planktonic community between the upstream and downstream parts of the reservoir. Phytoplankton densities and biovolumes generally were larger in the upstream part of the reservoir (sites $2 \mathrm{~B}$ and $3 \mathrm{~B}$ ) where phosphorus concentrations generally were not a limiting nutrient. However, the variations in phytoplankton that were measured in replicate samples and in samples that were collected concurrently from different depths at the same location were similar to the longitudinal variations. Additionally, a statistical analysis of the data indicated there were no consistent significant longitudinal differences. As the result of the large variations in phytoplankton densities and biovolumes in replicate samples and samples that were collected concurrently from different depths at the same location, and the lack of significant longitudinal differences, the phytoplankton data collected from discrete sites were combined and generally are discussed as a composite representation of the phytoplankton community in the reservoir.

\section{Occurrence of Phytoplankton}

From 1985 through 1989, about 285 different species of phytoplankton ranging in cell volume (size) from $1 \mu \mathrm{m}^{3}$ to more than $170,000 \mu \mathrm{m}^{3}$ were identified in Pueblo Reservoir. During this period, the planktonic community consisted of about 100 species of Bacillariophyta (diatoms), about 100 species of Chlorophyta (green algae), about 25 species of Chrysophyta (golden-brown algae), about 10 species of Cryptophyta (cryptomonads), about 30 species of Cyanophyta (blue-green algae), about 10 species of Euglenophyta (euglenoids), and about 10 species of Pyrrophyta (dinoflagellates). The species of diatoms, green algae, and golden-brown algae identified in Pueblo Reservoir generally range in size from 50 to $500 \mu^{3}$, although species were identified among these phyla that were considerably smaller and larger than this range. The species of blue-green algae identified in Pueblo Reservoir are very small and generally range in size from 1 to $50 \mu \mathrm{m}^{3}$ and commonly are referred to as nannoplankton; blue-green algae also have been referred to as cyanobacteria. The species of cryptomonads, euglenoids, and dinoflagellates identified in Pueblo Reservoir generally are greater than $500 \mu \mathrm{m}^{3}$ in size and commonly are referred to as macroplankton. Of all the species identified in Pueblo Reservoir, the dinoflagel- 

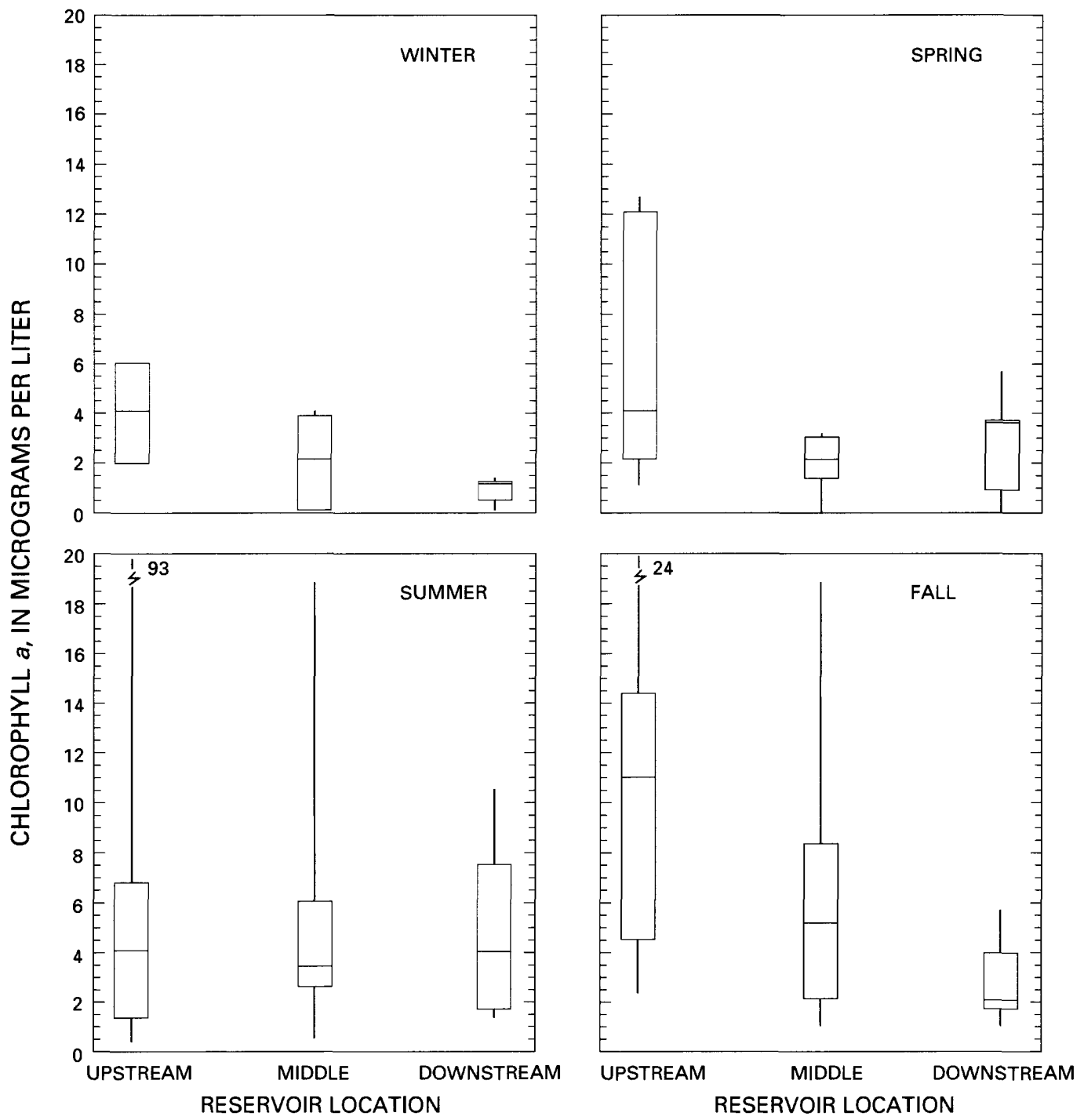

\section{EXPLANATION}

$\begin{array}{ll}24 & \text { MAXIMUM GREATER THAN } \\ 1 & \text { GRAPH SCALE } \\ \text { MAXIMUM } \\ 75 T H \text { PERCENTILE } \\ \text { MEDIAN } \\ \text { 25TH PERCENTILE } \\ \text { MINIMUM }\end{array}$

Figure 16. Chlorophyll a concentrations in Pueblo Reservoir near the reservoir surface, 1985 through 1987. 
lates are the largest; cell sizes generally ranged from 10,000 to $100,000 \mu^{3}$.

\section{Temporal Variation of Phytoplankton}

The temporal variations in phytoplankton densities and biovolumes that were measured from samples collected from Pueblo Reservoir from 1985 through 1987 are shown in figure 17. Though the variations in amplitude of phytoplankton densities and biovolumes are large, some generalizations can be made regarding seasonal variations of phytoplankton. Phytoplankton densities and biovolumes measured during the winter, spring, and fall tended to be smaller than phytoplankton densities and biovolumes measured during the summer. Most of the phytoplankton densities measured during the winter, spring, and fall ranged from about 2,000 to about 8,000 cells $/ \mathrm{mL}$. Most of the biovolumes measured during the winter, spring, and fall were less than $3,000,000 \mu \mathrm{m}^{3} / \mathrm{mL}$. Wetzel (1983) associated biovolumes ranging between $1,000,000$ and $3,000,000 \mu \mathrm{m}^{3} / \mathrm{mL}$ as being indicative of a small to moderate algal biomass. However, there were periods during the spring and fall when phytoplankton densities and biovolumes were substantially larger. During March 1986, biovolumes of 28,000,000 and $43,000,000 \mu \mathrm{m}^{3} / \mathrm{mL}$ were measured. Additionally, during the fall of 1987, phytoplankton densities were substantially larger than the densities measured during the fall of 1985 and 1986, indicating large algal blooms occur during the fall. The most notable fall bloom was during September 1987 when phytoplankton densities greater than 100,000 cells $/ \mathrm{mL}$ and biovolumes of $30,000,000$ and $56,000,000 \mu \mathrm{m}^{3} / \mathrm{mL}$ were measured. Wetzel (1983) associated biovolumes greater than $10,000,000 \mu \mathrm{m}^{3} / \mathrm{mL}$ as being indicative of excessive algal production and biomass.

Phytoplankton production tended to be largest during the summer when temperatures were the warmest and nutrient loads were the largest. Phytoplankton densities generally ranged from 10,000 to 30,000 cells $/ \mathrm{mL}$, and phytoplankton biovolumes generally ranged from $3,000,000$ to $10,000,000 \mu \mathrm{m}^{3} / \mathrm{mL}$. Wetzel (1983) associated biovolumes ranging between $3,000,000$ and $5,000,000 \mu \mathrm{m}^{3} / \mathrm{mL}$ as being indicative of a moderate to large algal biomass. In addition, the biovolume data indicate that excessive algal production (greater than $10,000,000 \mu \mathrm{m}^{3} / \mathrm{mL}$ ) periodically occurs in Pueblo Reservoir during the summer.

\section{Seasonal Succession of Dominant and Abundant Phytoplankton}

The seasonal succession of the planktonic community is reasonably constant from year to year as long as a reservoir is not perturbed by outside effects, such as human-induced changes to the watershed, changes in nutrient loading, and sediment loading (Wetzel, 1983).

The population of algae in the winter for many reservoirs commonly is dominated by small and motile algae such as Rhodomonas or Cryptomonas (Wetzel, 1983). During the winter sampling in December 1986, the phytoplankton community, as described using cell densities (fig. 18), predominately was comprised of cryptomonads and diatoms and to a lesser degree, green algae and blue-green algae. However, the phytoplankton biomass, as indicated by biovolumes, was most affected by cryptomonads, and a considerably smaller biomass contribution was from diatoms and dinoflagellates (fig. 18). The dominant algae species (species comprising more than 50 percent of a sample biomass) during December 1986 were the cryptomonad, Cryptomonas erosa, and the diatom, Stephanodiscus dubius (table 11). Other algae that were abundant (algae comprising more than 10 percent of a sample biomass) and contributed more than 10 percent of the biomass during the winter sampling are summarized in table 11 .

During the spring, as in many other lakes and reservoirs, diatoms generally were the most abundant phylum and had the largest biovolumes (fig. 19). Other phyla identified in the reservoir generally comprised less than 15 percent of the phytoplankton density and 10 percent of the biovolume. However, there were areas sampled in the reservoir that contained a moderate abundance of green algae, cryptomonads, and bluegreen algae. Wetzel (1983) indicates that spring blooms commonly are dominated by a few diatoms such as Asterionella, Cyclotella, or Stephanodiscus. The dominant algae identified in Pueblo Reservoir during the spring were the diatoms, Asterionella formosa and Stephanodiscus niagarae; and the cryptomonad, Cryptomonas reflexa (table 11). Other algae that were abundant and contributed more than 10 percent of the biomass during the spring are summarized in table 11 .

During the summer, diatoms and blue-green algae generally were the most abundant phyla in Pueblo Reservoir (fig. 20). However, as indicated by biovolume, diatoms and dinoflagellates contributed the most biomass, because of their large cell size (fig. 20). The median biovolume for the diatoms was $1,300,000 \mu \mathrm{m}^{3} / \mathrm{mL}$, and the median biovolume for the dinofiagellates was $4,100,000 \mu \mathrm{m}^{3} / \mathrm{mL}$. Because of 

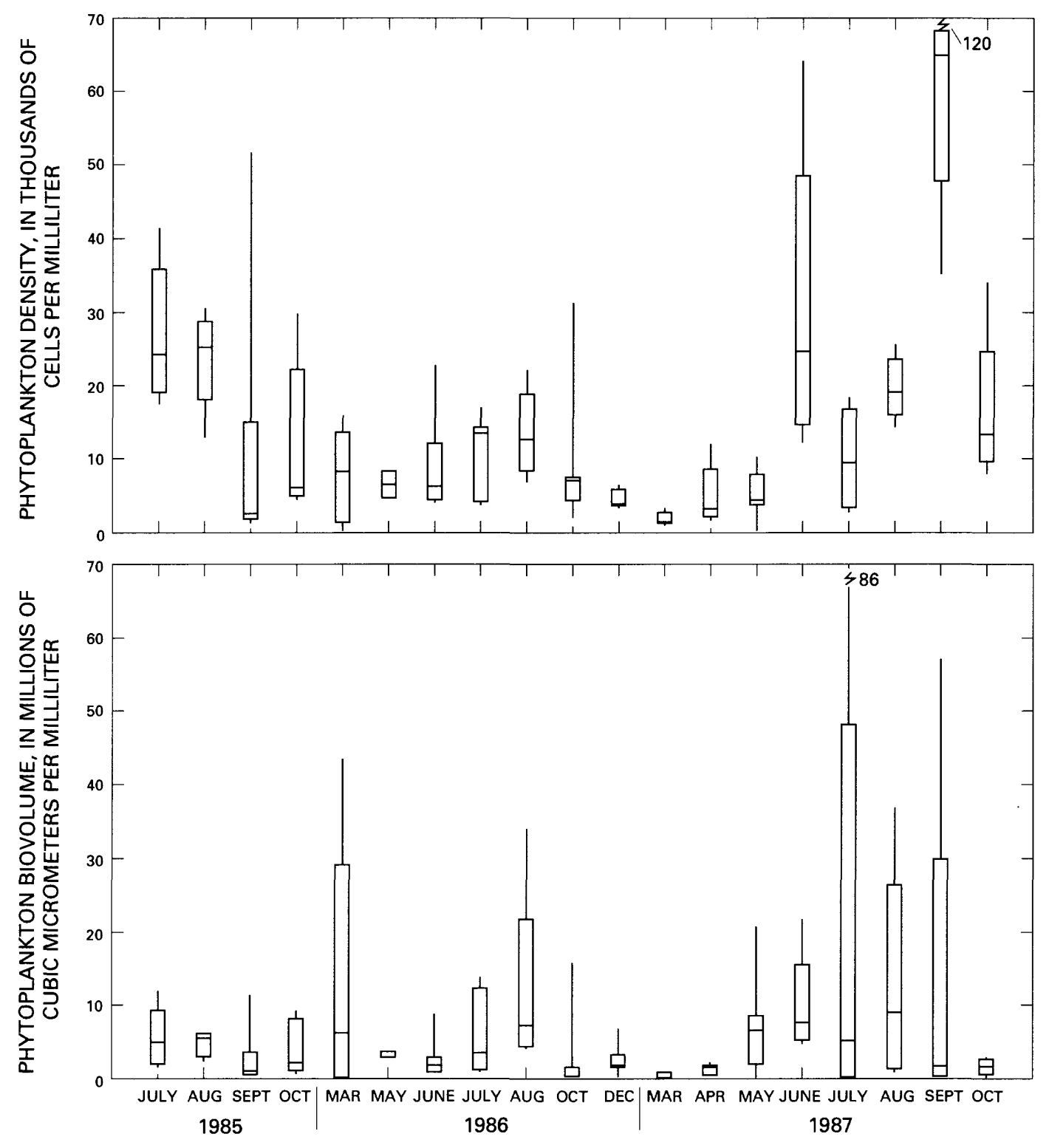

EXPLANATION

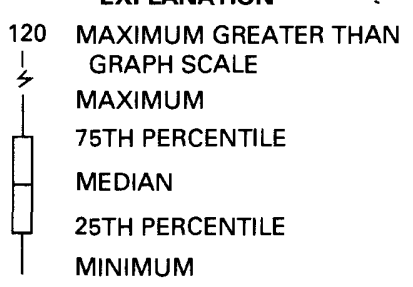

Figure 17. Phytoplankton density and biovolume in Pueblo Reservoir, 1985 through 1987. 

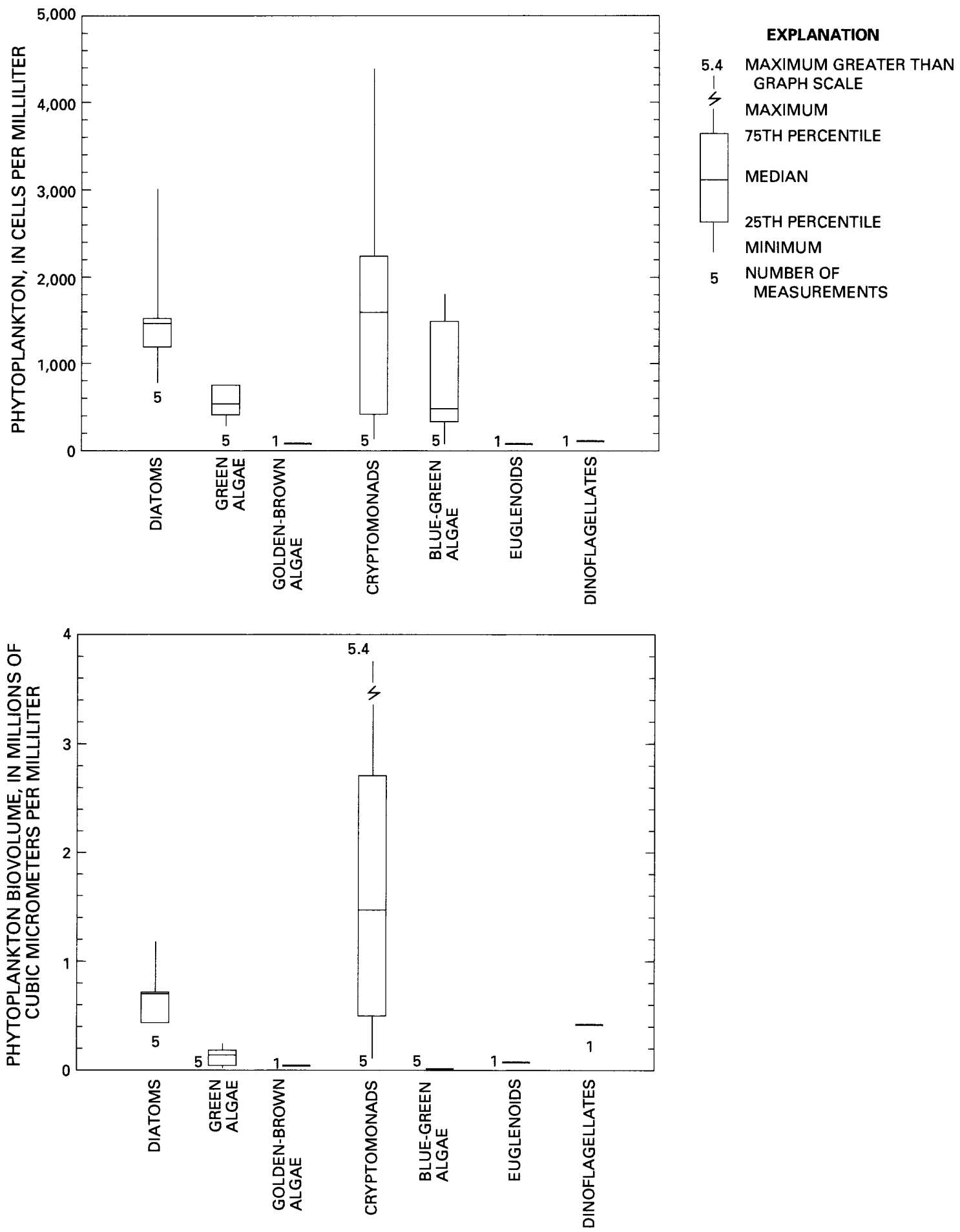

Figure 18. Major phytoplankton group densities and biovolumes in Pueblo Reservoir, winter 1986. 


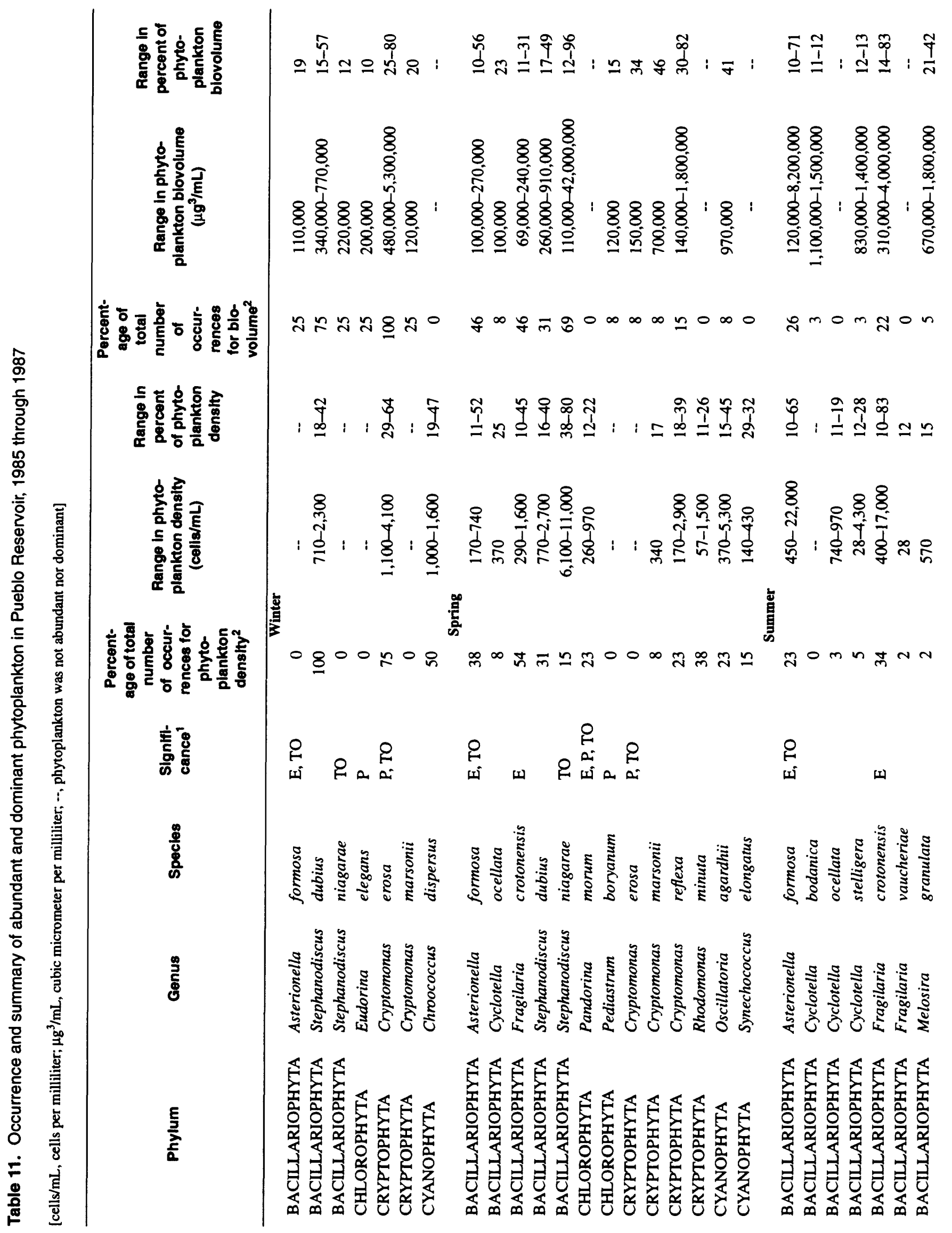




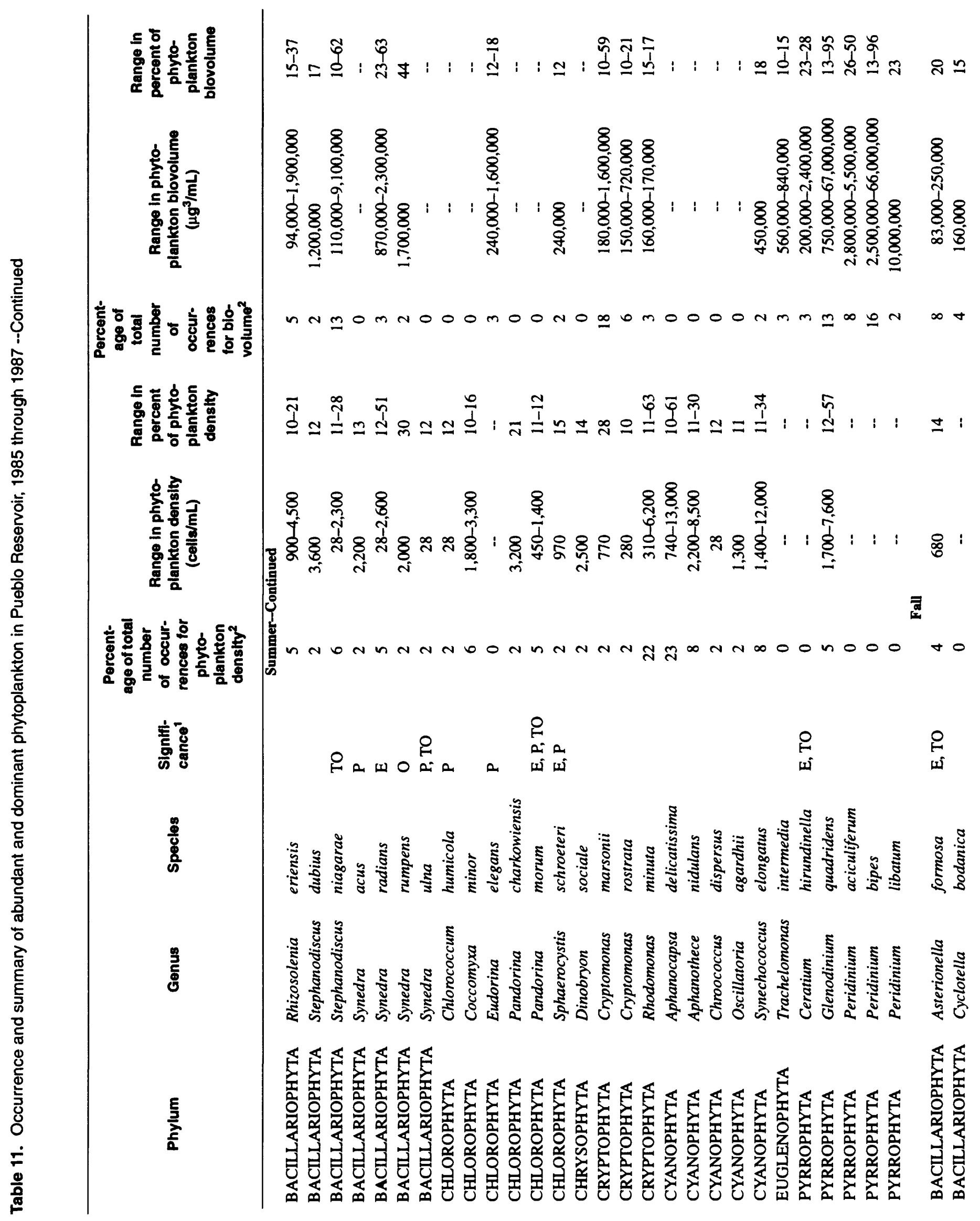




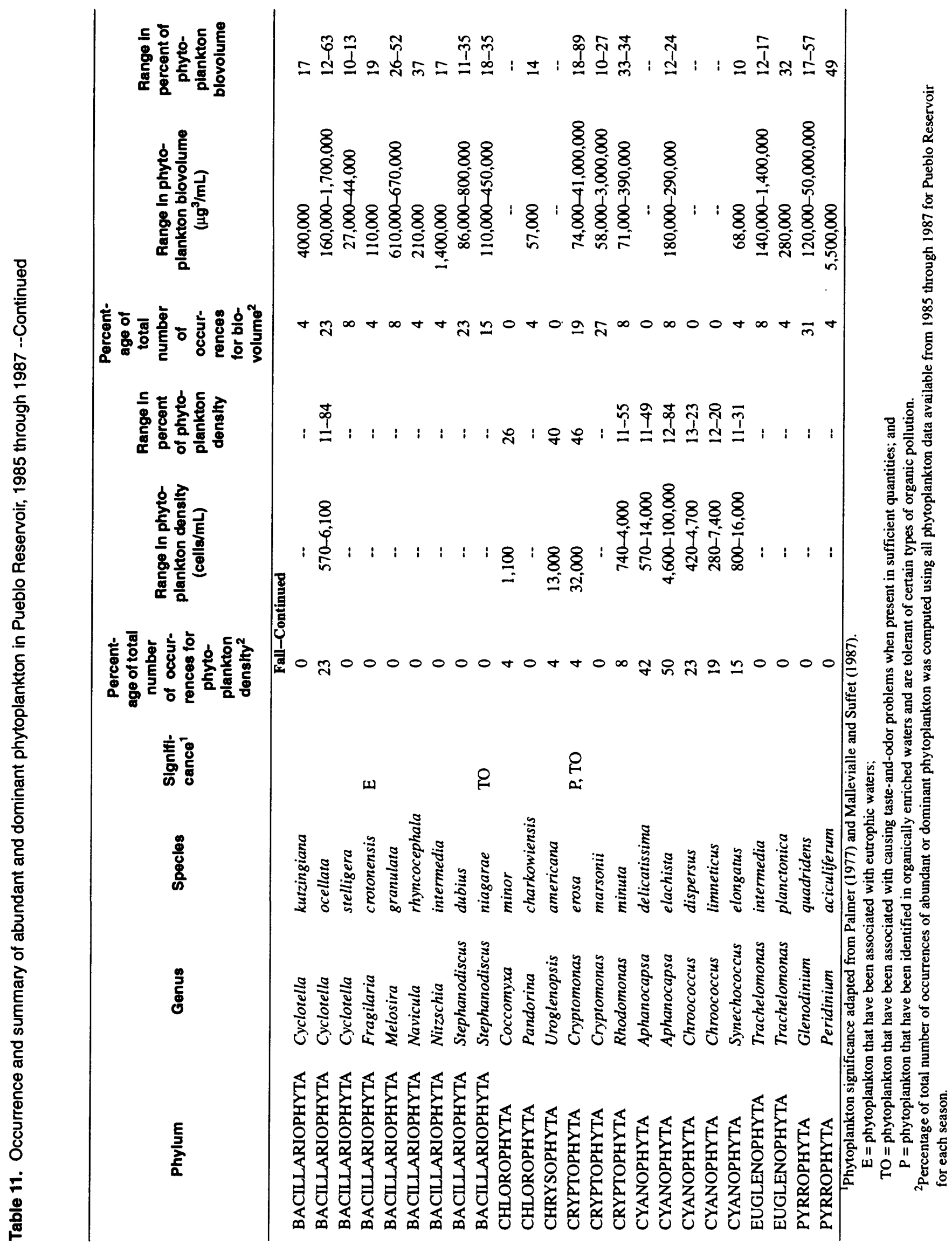



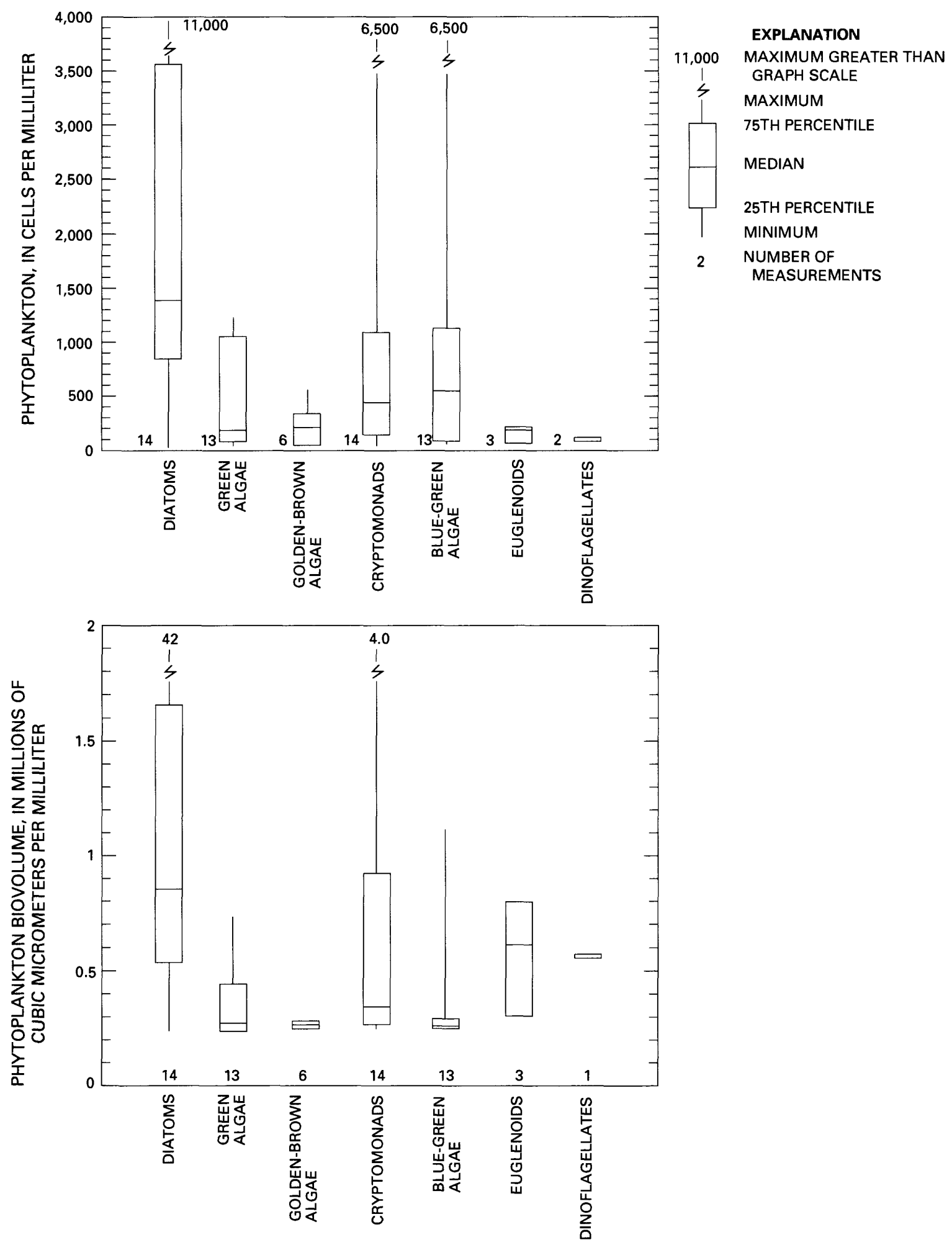

Figure 19. Major phytoplankton group densities and biovolumes in Pueblo Reservoir, spring 1986 and 1987. 

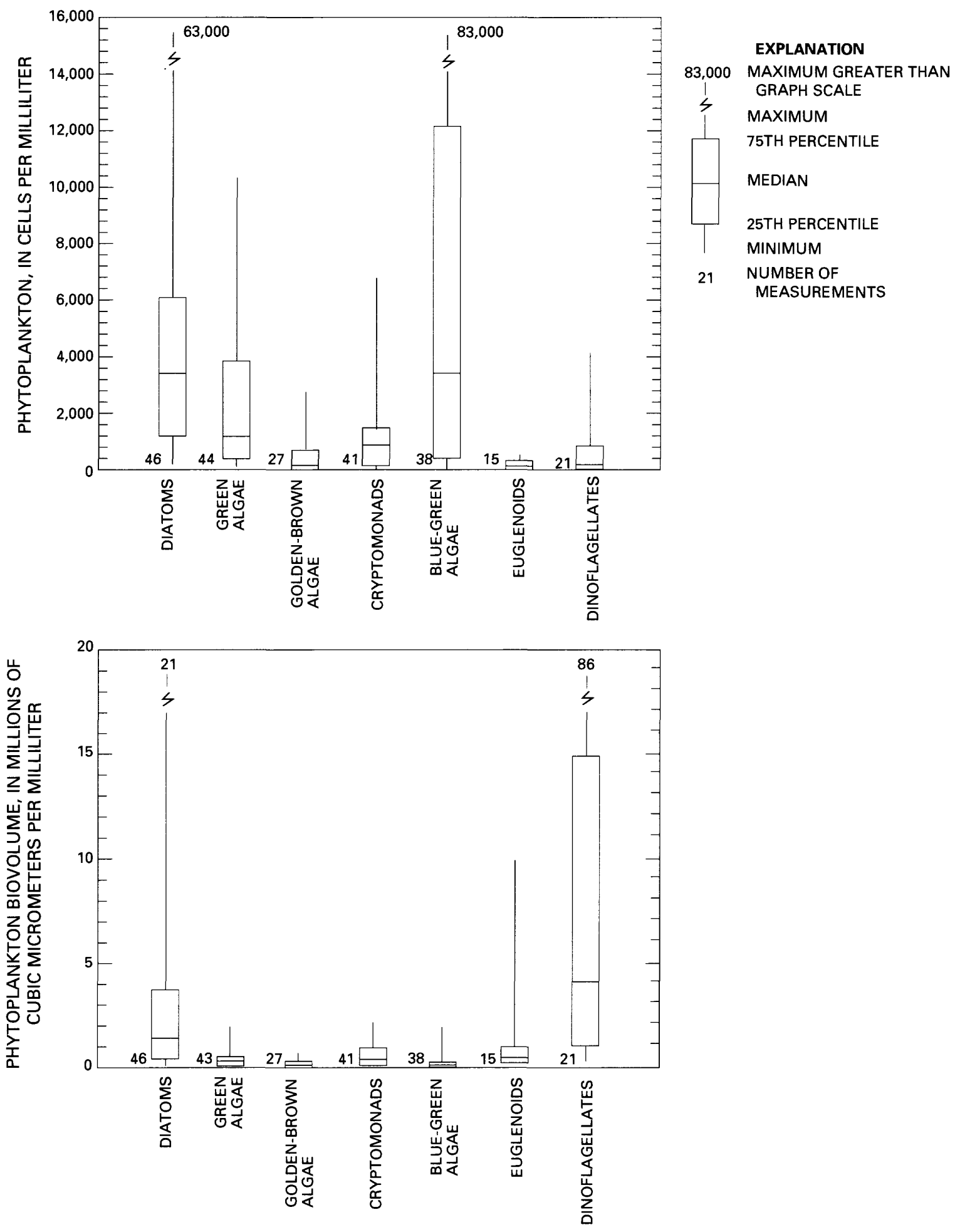

Figure 20. Major phytoplankton group densities and biovolumes in Pueblo Reservoir, summer 1985 through 1987. 
their very small cell size, the blue-green algae seldom comprised more than a few percent of the biovolume. Other phyla generally comprised less than 15 percent of the phytoplankton density and less than 10 percent of phytoplankton biovolume. However, there were occasions where green algae, cryptomonads, and euglenoids were abundant.

In many reservoirs, spring diatom blooms frequently are followed by a suppression of diatoms during the summer because of decreasing concentrations of silica (Wetzel, 1983)-silica is necessary for development of the cell walls of the diatoms. However, a constant supply of silica, typically ranging from 9 to $12 \mathrm{mg} / \mathrm{L}$ (Edelmann, 1988), from the Arkansas River to Pueblo Reservoir, may be the reason why a large diatom population is maintained in Pueblo Reservoir throughout the summer. The dominant algae identified in Pueblo Reservoir during the summer are summarized in table 11 and include the diatoms, Asterionella formosa, Fragilaria crotonensis, Stephanodiscus niagarae, and Synedra radians; the blue-green algae, Aphanocapsa delicatissima; the dinoflagellates, Glenodinium quadridens, Peridinium aciculiferum, and Peridinium bipes; and the cryptomonads, Cryptomonas marsonii and Rhodomonas minuta. Other algae that were abundant and contributed more than 10 percent of the biomass of a sample collected during the summer are summarized in table 11 .

During the fall, blue-green algae generally were the most abundant phylum (fig. 21). However, dinoflagellates generally contributed the largest biomass (fig. 21). As during the other seasons, their small cell size resulted in the blue-green algae seldom comprising more than a few percent of the biovolume. Diatoms generally comprised about 40 percent of the phytoplankton biovolume. Other phyla generally comprised less than 15 percent of the phytoplankton density and biovolume. However, there were occasions when green algae, golden-brown algae, cryptomonads, and euglenoids were abundant or contributed more than 10 percent of the phytoplankton biomass.

The dominant algae identified in Pueblo Reservoir during the fall are summarized in table 11 and include the blue-green alga, Aphanocapsa elachista; the dinoflagellate, Glenodinium quadridens; the diatoms, Cyclotella ocellata and Melosira granulata; and the cryptomonads, Cryptomonas erosa and Rhodomonas minuta. Other algae that were abundant during the fall and contributed more than 10 percent of the biomass are summarized in table 11 .

\section{Comparison of Phytoplankton Data for 1988 and 1989 with 1985 to 1987}

During 1988 and 1989, storage volumes were considerably smaller than during 1985 through 1987 (fig. 2). Phytoplankton data collected during 1988 and 1989 were compared empirically to phytoplankton data collected during 1985 through 1987. The limited phytoplankton data collected during 1988 and 1989 indicate the abundant phylum were similar to the phylum that generally were the most abundant from 1985 through 1987. The data collected during the summer of 1988 and 1989 indicate that diatoms and blue-green algae generally were the most abundant, and diatoms and dinoflagellates generally had the largest biovolumes. There also was an abundance of green algae, golden-brown algae, and cryptomonads. The phytoplankton densities and biovolume measured during the summer of 1988 and 1989 generally were comparable to those measured during the summer from 1985 through 1987. However, phytoplankton densities measured during August 1988 were considerably larger than those measured during August of the other years. During August 1988, the phytoplankton density measured at site 3B was 72,000 cells $/ \mathrm{mL}$, and at site $7 \mathrm{~B}$, the density was 75,000 cells $/ \mathrm{mL}$. Phytoplankton densities measured during August 1985-87 averaged about 20,000 cells $/ \mathrm{mL}$. This apparent anomaly may be, at least in part, due to a 30 to 35 percent decrease in the theoretical flushing rate during the summer of 1988 as compared to the theoretical flushing rates during the summers of 1985, 1986, and 1989.

The dominant algae identified during the summer of 1988 and 1989 included the diatoms, Asterionella formosa and Fragilaria crotonensis; the bluegreen alga, Aphanocapsa elachista; and the dinoflagellates, Glenodinium quadridens and Peridinium inconspicuum. During the fall of 1989 , diatoms, cryptomonads and blue-green algae were the phyla that generally were the most abundant. Diatoms, cryptomonads, and dinoflagellates had the largest biovolumes. No taxa were dominant in terms of cell density, and the only taxa that comprised more than 50 percent of the phytoplankton biomass in terms of biovolume was the cryptomonad, Cryptomonas erosa.

\section{Relations of Phytoplankton to Water-Quality Conditions}

Several limnological investigations have been devoted to describing the associations of algae to various water-quality conditions. The diversity of algae is large, and most algae have a wide tolerance to a broad range of environmental conditions (Greeson, 1982; 

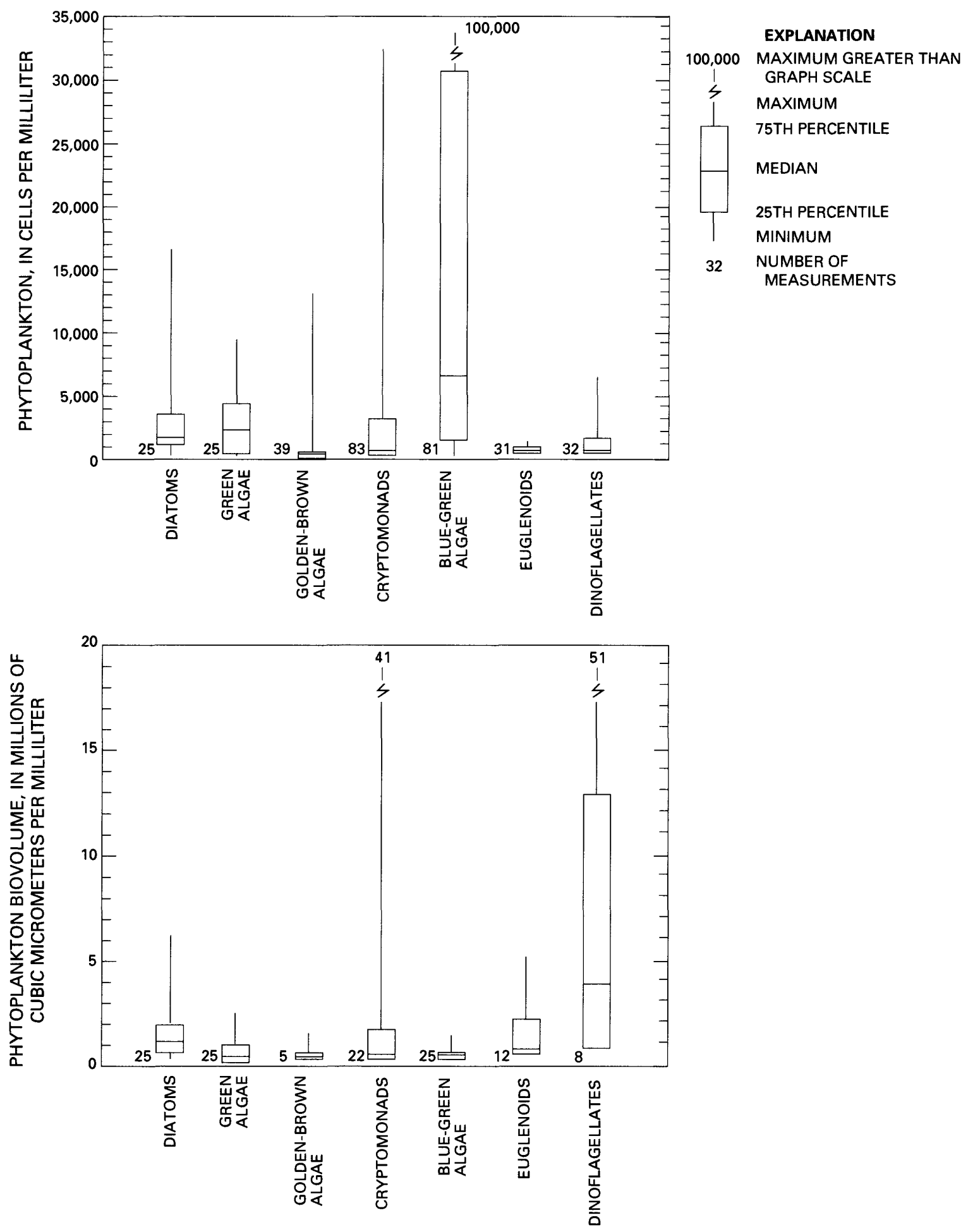

Figure 21. Major phytoplankton group densities and biovolumes in Pueblo Reservoir, fall 1985 through 1987. 
Wetzel, 1983). Therefore, the presence of certain algae does not mean that a water-quality problem exists, or that these algae will cause a particular water-quality problem. However, an abundance or dominance of certain algae are characteristic and occur repeatedly in lakes of increasing nutrient enrichment. Therefore, certain characteristic algal associations can provide a qualitative understanding of the availability of nutrients. There were several algae that were in abundance in Pueblo Reservoir that predominate in eutrophic waters (table 11). These include: the diatoms, Asterionella formosa, Fragilaria crotonensis, and Synedra radians; the green algae, Pandorina morum and Sphaerocystis schroeteri; and the dinoflagellate, Ceratium hirundinella. Asterionella formosa was abundant in all four seasons. Fragilariacrotonensis was abundant during the spring, summer, and fall. Synedra radians, Sphaerocystis schroeteri, and Ceratium hirundinella were abundant only during the summer. Pandorina morum was abundant during the spring and summer.

An analyses of the phytoplankton associated with taste-and-odor problems was made because the reservoir is used as a drinking-water supply, and potential odor problems can adversely affect the aesthetic use of the reservoir for recreational purposes. For a particular species to cause taste-and-odor problems, it generally must be present in sufficient quantities to produce taste-and-odor compounds in large enough quantities to produce an offensive taste or odor, or both. Palmer (1977), which Mallevialle and Suffet (1987) considered to be one of the most comprehensive references on algal tastes and odors, related the presence of taste and odors to the occurrence of either a moderate quantity or abundance of a particular genus and species. However, Palmer did not quantify the terms "moderate quantity" or "abundance".

Mallevialle and Suffet (1987) provided a tabulation, originally prepared by Seppovaara (1971), of critical threshold densities of selected genera of algae that produce odorous metabolites. By using this information, a comparison was made of the critical threshold concentrations provided in Mallevialle and Suffet (1987) to the concentrations measured for the corresponding genera identified in Pueblo Reservoir. The results of this comparison indicate that there were 78 occurrences among the phytoplankton samples collected from Pueblo Reservoir from 1985 through 1989 that exceeded the critical threshold concentrations (table 12). In addition, exceedances occurred during each season, which indicates nuisance algae can occur in large enough numbers during each season in Pueblo Reservoir to produce taste-and-odor metabolites. During the winter, the green algae, Eudorina and Pando- rina; and the cryptomonad, Cryptomonas, were the genera that exceeded the critical threshold concentrations. During the spring, the genera that exceeded the critical threshold concentrations included the green alga, Pandorina, and the cryptomonad, Cryptomonas. During the summer, the genus that exceeded the critical threshold concentrations most frequently was the green alga, Pandorina; other genera exceeding the critical threshold concentrations during the summer included the green algae, Eudorina and Scenedesmus; the golden-brown algae, Mallomonas and Synura; and the diatoms, Asterionella and Cyclotella. During the fall, the genus that exceeded the critical threshold concentrations most frequently was, again, the green alga, Pandorina; other genera exceeding the critical threshold concentrations during the fall included the diatoms, Cyclotella and Melosira; and the cryptomonad, Cryptomonas. Several of the genera that were identified as having critical taste-and-odor threshold concentrations include species that have not been associated with taste-and-odor problems. Therefore, it is important to assess which species among the above mentioned genera were present in Pueblo Reservoir in sufficient quantities to cause taste-and-odor problems. Three species specifically associated with causing taste-and-odor problems were present in quantities that exceeded the critical threshold concentrations; these algae were present in 63 percent of the occurrences exceeding taste-and-odor threshold concentrations and include the diatom, Asterionella formosa; the green alga, Pandorina morum; and the cryptomonad, Cryptomonas erosa.

Asterionella has been described as producing a spicy and Geranium odor when present in moderate quantities and a fishy odor when present in large quantities. Pandorina has been described as producing a fishy odor when present in large quantities. Cryptomonas has been described as producing a Violet odor when present in moderate quantities and producing a Violet or fishy odor when present in large quantities. During the winter of 1986, Cryptomonas erosa concentrations exceeded the critical concentration at sites 2B and 5C. During the spring of 1987, Pandorina morum exceeded the critical concentration at multiple sites. During the summers of 1985-89, Pandorina morum exceeded the critical concentration at various sites; in addition, Asterionella formosa exceeded the critical concentration at various reservoir sites during the summers of 1986-88. During the fall of 1986 and 1987, Cryptomonas erosa exceeded the critical concentration at site 2B; additionally, Pandorina morum exceeded the critical concentration at sites $2 \mathrm{~B}, 3 \mathrm{~B}$, and $5 \mathrm{C}$ during the fall of 1987 and, during the fall of 1989, Pandorina morum exceeded the critical concentration at site $3 \mathrm{~B}$. 
Table 12. Occurrence of phytoplankton in Pueblo Reservoir that exceed the critical taste-and-odor threshold concentrations, $1985-89$

[cells/mL, cells per milliliter; sp., species are distinguishable but not identifiable]

\begin{tabular}{|c|c|c|c|c|c|c|}
\hline $\begin{array}{l}\text { Sampling } \\
\text { site }^{1}\end{array}$ & $\begin{array}{l}\text { Date of } \\
\text { sample }\end{array}$ & Phylum & Genus & Species & $\begin{array}{c}\text { Phytoplankton } \\
\text { density } \\
\text { (cells/mL) }\end{array}$ & $\begin{array}{c}\text { Percent } \\
\text { of } \\
\text { threshold }{ }^{2}\end{array}$ \\
\hline \multicolumn{7}{|c|}{ Winter } \\
\hline $2 B$ & $12 / 02 / 86$ & CRYPTOPHYTA & Cryptomonas & erosa & 4,100 & 340 \\
\hline $5 \mathrm{C}$ & $12 / 03 / 86$ & CHLOROPHYTA & Pandorina & sp. & 230 & 110 \\
\hline $5 C$ & $12 / 03 / 86$ & CRYPTOPHYTA & Cryptomonas & erosa & 2,000 & 170 \\
\hline $6 \mathrm{C}$ & $12 / 04 / 86$ & CHLOROPHYTA & $\begin{array}{c}\text { Eudorina } \\
\text { Spring }\end{array}$ & elegans & 230 & 280 \\
\hline $2 B$ & $03 / 11 / 87$ & CHLOROPHYTA & Pandorina & morum & 710 & 360 \\
\hline $3 B$ & $03 / 24 / 86$ & CRYPTOPHYTA & Cryptomonas & reflexa & 2,900 & 240 \\
\hline 3B & $03 / 12 / 87$ & CHLOROPHYTA & Pandorina & morum & 260 & 130 \\
\hline $5 C$ & $03 / 26 / 86$ & CRYPTOPHYTA & Cryptomonas & reflexa & 2,300 & 190 \\
\hline $5 \mathrm{C}$ & $04 / 16 / 87$ & CHLOROPHYTA & Pandorina & morum & 970 & 480 \\
\hline $6 C$ & $04 / 16 / 87$ & CHLOROPHYTA & $\begin{array}{l}\text { Pandorina } \\
\text { Summer }\end{array}$ & morum & 740 & 370 \\
\hline $2 B$ & $07 / 15 / 85$ & BACILLARIOPHYTA & Cyclotella & stelligera & 4,300 & 200 \\
\hline $2 B$ & $07 / 15 / 85$ & CHRYSOPHYTA & Mallomonas & sp. & 570 & 130 \\
\hline $2 B$ & $08 / 15 / 85$ & CHRYSOPHYTA & Synura & sp. & 450 & 4,500 \\
\hline $2 B$ & $08 / 20 / 86$ & BACILLARIOPHYTA & Cyclotella & stelligera & 4,300 & 190 \\
\hline $2 B$ & $08 / 20 / 86$ & CHLOROPHYTA & Pandorina & charkowiensis & 3,200 & 1,600 \\
\hline $3 B$ & $07 / 16 / 85$ & BACILLARIOPHYTA & Cyclotella & stelligera & 7,300 & 330 \\
\hline $3 B$ & $07 / 16 / 85$ & CHLOROPHYTA & Pandorina & morum & 680 & 340 \\
\hline $3 B$ & $08 / 19 / 85$ & CHLOROPHYTA & Pandorina & morum & 680 & 340 \\
\hline $3 B$ & $08 / 19 / 85$ & CHLOROPHYTA & Scenedesmus & serratus & 1,900 & 130 \\
\hline $3 B$ & $06 / 24 / 86$ & CHLOROPHYTA & Eudorina & elegans & 1,800 & 2,300 \\
\hline $3 B$ & $06 / 24 / 86$ & CHLOROPHYTA & Pandorina & charkowiensis & 910 & 460 \\
\hline $3 B$ & $06 / 24 / 86$ & CHLOROPHYTA & Pandorina & morum & 680 & 340 \\
\hline $3 B$ & $08 / 22 / 86$ & CHLOROPHYTA & Pandorina & charkowiensis & 570 & 290 \\
\hline $3 B$ & $05 / 12 / 87$ & CHLOROPHYTA & Pandorina & morum & 570 & 280 \\
\hline $3 B$ & $05 / 12 / 87$ & CHLOROPHYTA & Pandorina & morum & 230 & 110 \\
\hline $3 B$ & $06 / 10 / 87$ & BACILLARIOPHYTA & Asterionella & formosa & 3,100 & 100 \\
\hline $3 B$ & $06 / 10 / 87$ & CHLOROPHYTA & Pandorina & morum & 970 & 480 \\
\hline $3 B$ & $07 / 15 / 87$ & CHLOROPHYTA & Eudorina & elegans & 110 & 140 \\
\hline $3 B$ & $07 / 15 / 87$ & CHLOROPHYTA & Pandorina & morum & 910 & 460 \\
\hline $3 B$ & $07 / 15 / 87$ & CHLOROPHYTA & Pandorina & morum & 430 & 210 \\
\hline $3 B$ & $08 / 11 / 87$ & CHLOROPHYTA & Pandorina & morum & 340 & 170 \\
\hline $3 B$ & $08 / 11 / 87$ & CHLOROPHYTA & Pandorina & morum & 450 & 230 \\
\hline $3 B$ & $06 / 27 / 89$ & CHLOROPHYTA & Pandorina & morum & 620 & 310 \\
\hline $5 C$ & $06 / 25 / 86$ & CHLOROPHYTA & Eudorina & elegans & 280 & 360 \\
\hline $5 C$ & $05 / 15 / 87$ & CHLOROPHYTA & Pandorina & morum & 620 & 310 \\
\hline $5 C$ & $06 / 11 / 87$ & BACILLARIOPHYTA & Asterionella & formosa & 11,000 & 370 \\
\hline $5 C$ & $07 / 16 / 87$ & CHLOROPHYTA & Eudorina & elegans & 230 & 280 \\
\hline $5 C$ & $07 / 16 / 87$ & CHLOROPHYTA & Pandorina & morum & 330 & 160 \\
\hline $5 C$ & $07 / 16 / 87$ & CHLOROPHYTA & Pandorina & morum & 910 & 460 \\
\hline $5 C$ & $08 / 13 / 87$ & CHLOROPHYTA & Pandorina & morum & 680 & 340 \\
\hline
\end{tabular}


Table 12. Occurrence of phytoplankton in Pueblo Reservoir that exceed the critical taste-and-odor threshold concentrations, 1985-89 --Continued

\begin{tabular}{|c|c|c|c|c|c|c|}
\hline $\begin{array}{l}\text { Sampling } \\
\text { site }^{1}\end{array}$ & $\begin{array}{l}\text { Date of } \\
\text { sample }\end{array}$ & Phylum & Gonus & Species & $\begin{array}{l}\text { Phytoplankton } \\
\text { density } \\
\text { (celis/mL) }\end{array}$ & $\begin{array}{c}\text { Percent } \\
\text { of } \\
\text { threshold }\end{array}$ \\
\hline \multicolumn{7}{|c|}{ Summer-Continued } \\
\hline $6 C$ & $05 / 22 / 86$ & BACILLARIOPHYTA & Asterionella & formosa & 3,500 & 120 \\
\hline $6 C$ & $07 / 11 / 86$ & BACILLARIOPHYTA & Asterionella & formosa & 3,200 & 110 \\
\hline $6 \mathrm{C}$ & $07 / 11 / 86$ & CHLOROPHYTA & Pandorina & charkowiensis & 680 & 340 \\
\hline $6 C$ & $05 / 18 / 87$ & CHLOROPHYTA & Pandorina & morum & 510 & 260 \\
\hline $6 C$ & $06 / 11 / 87$ & BACILLARIOPHYTA & Asterionella & formosa & 15,000 & 500 \\
\hline $6 C$ & $07 / 16 / 87$ & CHLOROPHYTA & Pandorina & morum & 450 & 230 \\
\hline $7 \mathrm{~B}$ & $08 / 25 / 86$ & CHLOROPHYTA & Pandorina & charkowiensis & 230 & 110 \\
\hline $7 \mathrm{~B}$ & $05 / 19 / 87$ & CHLOROPHYTA & Pandorina & morum & 1,400 & 720 \\
\hline $7 \mathrm{~B}$ & $06 / 12 / 87$ & BACILLARIOPHYTA & Asterionella & formosa & 18,000 & 580 \\
\hline $7 \mathrm{~B}$ & $07 / 13 / 88$ & BACILLARIOPHYTA & Asterionella & formosa & 5,300 & 180 \\
\hline 7B & $07 / 13 / 88$ & CHLOROPHYTA & Pandorina & morum & 410 & 200 \\
\hline $7 \mathrm{~B}$ & $06 / 12 / 87$ & BACILLARIOPHYTA & Asterionella & formosa & 22,000 & 730 \\
\hline $7 \mathrm{~B}$ & $06 / 12 / 87$ & BACILLARIOPHYTA & Asterionella & formosa & 22,000 & 740 \\
\hline $7 \mathrm{~B}$ & $06 / 12 / 87$ & BACILLARIOPHYTA & Asterionella & formosa & 8,500 & 280 \\
\hline $7 \mathrm{~B}$ & $07 / 17 / 87$ & CHLOROPHYTA & Eudorina & elegans & 170 & 210 \\
\hline $7 \mathrm{~B}$ & $07 / 17 / 87$ & CHLOROPHYTA & Pandorina & morum & 450 & 230 \\
\hline $7 \mathrm{~B}$ & $07 / 17 / 87$ & CHLOROPHYTA & Pandorina & morum & 1,200 & 620 \\
\hline $7 \mathrm{~B}$ & $07 / 17 / 87$ & CHLOROPHYTA & Pandorina & morum & 2,700 & 1,400 \\
\hline $7 \mathrm{~B}$ & $07 / 17 / 87$ & CHLOROPHYTA & $\begin{array}{c}\text { Pandorina } \\
\text { Fall }\end{array}$ & morum & 230 & 110 \\
\hline 2B & $09 / 24 / 85$ & BACILLARIOPHYTA & Cyclotella & ocellata & 6,100 & 280 \\
\hline $2 B$ & $09 / 24 / 85$ & BACILLARIOPHYTA & Melosira & sp. & 3,900 & 150 \\
\hline $2 B$ & $10 / 23 / 85$ & BACILLARIOPHYTA & Melosira & sp. & 8,600 & 340 \\
\hline $2 B$ & $10 / 22 / 86$ & CHLOROPHYTA & Pandorina & charkowiensis & 910 & 460 \\
\hline $2 B$ & $10 / 22 / 86$ & CRYPTOPHYTA & Cryptomonas & erosa & 2,300 & 190 \\
\hline $2 B$ & $09 / 15 / 87$ & BACILLARIOPHYTA & Melosira & sp. & 2,600 & 100 \\
\hline 2B & $09 / 15 / 87$ & CHLOROPHYTA & Pandorina & morum & 1,800 & 910 \\
\hline 2B & $09 / 15 / 87$ & CRYPTOPHYTA & Cryptomonas & marsonii & 1,500 & 120 \\
\hline $2 B$ & $10 / 20 / 87$ & CRYPTOPHYTA & Cryptomonas & erosa & 32,000 & 2,600 \\
\hline 3B & $09 / 24 / 85$ & CHLOROPHYTA & Pandorina & charkowiensis & 1,400 & 680 \\
\hline 3B & $10 / 23 / 85$ & BACILLARIOPHYTA & Melosira & sp. & 11,000 & 450 \\
\hline 3B & $09 / 15 / 87$ & CHLOROPHYTA & Pandorina & morum & 1,500 & 740 \\
\hline 3B & $09 / 15 / 87$ & CHLOROPHYTA & Pandorina & morum & 3,600 & 1,800 \\
\hline 3B & $09 / 15 / 87$ & CHLOROPHYTA & Pandorina & morum & 1,400 & 680 \\
\hline $3 B$ & $09 / 15 / 87$ & CHLOROPHYTA & Pandorina & morum & 450 & 230 \\
\hline 3B & $10 / 21 / 87$ & CHLOROPHYTA & Pandorina & morum & 910 & 460 \\
\hline 3B & $09 / 27 / 89$ & CHLOROPHYTA & Pandorina & morum & 390 & 200 \\
\hline $5 \mathrm{C}$ & $10 / 23 / 86$ & CHLOROPHYTA & Pandorina & charkowiensis & 280 & 140 \\
\hline $5 \mathrm{C}$ & $09 / 16 / 87$ & CHLOROPHYTA & Pandorina & morum & 230 & 110 \\
\hline
\end{tabular}


Other potential biological sources of taste-andodor problems in Pueblo Reservoir could include periphyton (algae that are attached to the reservoir walls), decomposition of algae that can cause taste and odors by cell lysis and by providing dead biomass to support bacterial growth, actinomycetes (a bacteria), protozoans, and fungi (Mallevialle and Suffet, 1987).

\section{WATER QUALITY AND RESERVOIR- OPERATION CONSIDERATIONS}

Maintaining the quality of water in Pueblo Reservoir is important in maximizing the various uses of the reservoir. The quality of water in the reservoir is the result of the quality of inflowing water and the physical, chemical, and biological processes in the reservoir. In addition, reservoir operations and hydrodynamics can substantially affect processes that affect reservoir water quality. Active management of the reservoir for water-quality purposes requires an understanding of how reservoir operations and hydrodynamics and changes in the watershed may affect water quality. This section of the report provides a conceptualization of how residence times, stratification, underflow, hypolimnetic withdrawals, and changes in nutrient, metal, and sediment inputs to the reservoir may affect the quality of water in the reservoir.

Historically, the annual volume of water that passes through Pueblo Reservoir has been greater than the volume of water stored in the reservoir, which results in relatively short residence times. On the average between 1985 and 1989 , the reservoir volume has been exchanged once between September through April. Additionally, large reservoir releases, thermal stratification, and predominant underflow of the Arkansas River inflow during the summer have resulted in residence times for portions of water in the reservoir to be as short as a month. Between May and August, an average volume equivalent to two reservoir volumes have been exchanged, which indicates large flushing rates during the summer in Pueblo Reservoir.

Because of mixing, the quality of water throughout almost the entire reservoir is similar from October through March. However, stratification, underflow, and hypolimnetic withdrawals affect concentrations of dissolved solids, availability of nutrients, and concentrations of metals in the reservoir from May through August. Stratification impedes the mixing of the epilimnetic and hypolimnetic waters, and the prevalent underflow that occurs during the summer results in a decrease in potential dilution of inflowing river water with reservoir water. Underflow decreases the maximum available nutrient load to the euphotic zone that can, in turn, offset the maximum algal growth potential.
As summer progresses, concentrations of dissolved solids, nutrients, and selected metals increase in the hypolimnion because of their higher concentrations in the inflowing river water and because of releases of substances from the oxygen-deficient bottom sediments. The increase in dissolved solids, nutrients, and metals in the hypolimnion during the summer partially is offset by hypolimnetic withdrawals. During the summer, the large withdrawals from the river outlets, which are located in the hypolimnion, result in the flushing of dissolved solids, nutrients, and metals from much of the hypolimnion. The large hypolimnetic withdrawals also can result in a diminished nutrient load from the hypolimnetic waters to the euphotic zone during fall turnover and assist reservoir mixing at the dam in late August to mid-September.

Potential in-basin contaminants include dissolved solids, major nutrients, and trace elements that are associated primarily with land and water use and hydrogeological processes in the watershed. Changes to the watershed that result in changes in dissolvedsolids concentrations and nutrient, metal, and sediment inputs to Pueblo Reservoir could affect the reservoir and its long-term usability.

The dissolved-solids concentrations of water at station 07099400, Arkansas River above Pueblo, has exceeded the Secondary Maximum Contaminant Level of $500 \mathrm{mg} / \mathrm{L}$ about 10 percent of the time (Cain, 1987). Doug Cain (U.S. Geological Survey, written commun., 1987) also estimated that an average increase in dissolved-solids concentrations of about $100 \mathrm{mg} / \mathrm{L}$ would cause this standard to be exceeded from 30 to 40 percent of the time. Increases in wastewater discharges, irrigation-return flows, saline ground-water inflows, decreases in streamflow, or increases in evaporation could result in more frequent occurrences of concentrations in excess of $500 \mathrm{mg} / \mathrm{L}$, which could impair the use of the reservoir as a water supply.

Currently, nitrogen and phosphorus inputs to the reservoir generally are large enough to sustain a small to moderate algal biomass during the winter, spring, and fall; during the summer, sufficient nutrients are available to sustain a moderate to large algal biomass. Additionally, excessive algal biomass periodically has been measured during the spring, summer, and fall. A decrease in nutrient inputs, especially phosphorus, could: (1) decrease algal biomass and productivity; (2) decrease the availability of organic matter for decomposition, resulting in a decrease in the occurrence and extent of the oxygen deficit in the hypolimnion; and (3) minimize reducing conditions at the reservoir water-sediment interface, resulting in diminished releases of nutrients and metals from bottom sediments. Conversely, an increase in nutrient inputs, 
especially phosphorus, could: (1) increase algal biomass and productivity; (2) increase the availability of organic matter for decomposition, resulting in an increase in the occurrence and extent of the oxygen deficit in the hypolimnion; and (3) increase reducing conditions at the reservoir water-sediment interface, resulting in increased releases of nutrients and metals from bottom sediments.

Several Federal and State agencies expect the remediation of metal-mine discharges in the Leadville area to result in substantially reduced metal concentrations and loads in the upper basin. However, because substantial concentrations of selected metals are present now in the bottom sediments of Pueblo Reservoir, remediation of mine drainage would not be expected to result in a change in metal releases from bottom sediments. The metal fluxes from the reservoir sediments will be affected mostly by reducing conditions and sedimentation (burial) rates of new sediments.

Effective watershed management also can decrease the disturbance of soil and subsequent erosion and transport of sediments to the reservoir. Maintaining good vegetative cover in the basin and around the reservoir helps to prevent excessive erosion of the watershed. The Bureau of Land Management and other Federal, State, and private entities have been implementing erosional control measures in areas of the upper Arkansas River Basin. Efforts such as these to offset the overgrazing that has occurred in the basin might result in decreasing sediment inputs to the reservoir which could: (1) increase the aesthetic value of the reservoir; (2) increase light availability for algal growth and, in turn, increase algal biomass; and (3) decrease sedimentation rates within the reservoir which, in turn, could increase the diffusion rate of substances being released from the bottom sediments. Conversely, increases in sedimentation rates could: (1) decrease the available storage volume in the reservoir, and (2) decrease the diffusion rate of substances being released from bottom sediments.

The occurrence and abundance of taste-andodor-causing algae, the large algal biomass in the reservoir, and the dissolved-oxygen depletion in the hypolimnion of the reservoir during the summer indicate that active reservoir-basin planning, management, and water-quality control is important in continuing to maximize the various uses of the reservoir. Although it is not possible to quantitatively predict the benefits of various management plans on the quality of water in the reservoir, it is important to be aware of the benefits of maintaining short residence times, maximizing flushing rates, and minimizing phosphorus inputs to the reservoir. It is also important to continue to monitor the water quality of the reservoir and its inflow and outflow because the effects of changes in reservoir operations or watershed conditions cannot be quantitatively predicted.

\section{SUMMARY}

Pueblo Reservoir is a multipurpose, main-stem reservoir constructed on the Arkansas River about $6 \mathrm{mi}$ west of Pueblo. The reservoir is a municipal water supply to the cities of Pueblo and Pueblo West, the primary water supply to St. Charles Mesa, and supplements the water supplies of Colorado Springs, Stratmoor Hills, Security, Widefield, and Fountain. At the top of the conservation pool, the reservoir surface elevation is about $4,880 \mathrm{ft}$, the reservoir is more than $9 \mathrm{mi}$ long and ranges in depth from a few feet at the inflow to about $155 \mathrm{ft}$ at the dam. Pueblo Reservoir derives almost all of its contents from the Arkansas River, which comprises native and transmountain flow.

During 1985 through 1989, a consistent annual pattern of thermal stratification and mixing was observed in Pueblo Reservoir. The reservoir typically was well mixed in the early spring and gradually became strongly stratified by May. Strong thermal stratification persisted in the reservoir before being disrupted by surface cooling and the subsequent fall turnover in August and September. During May through September, inflow from the Arkansas River entered primarily as interflow and underflow. Weak thermal stratification to well-mixed conditions were observed from late fall through the winter and into early spring.

Hydraulic residence times ranged from several weeks to several months. Residence times were as short as about 30 days during periods of strong thermal stratification and large streamflows from the Arkansas River. This condition typically occurred in June and July and resulted from underflow of the Arkansas River short-circuiting parts of the reservoir before being discharged at the dam.

Water transparency, as measured with a Secchi disk, varied spatially and seasonally. Secchi-disk depths increased in a downstream direction from the reservoir inflow. The increase probably was a result of much of the inflow sediment load settling from the water column in the upstream part of the reservoir. Secchi-disk depths were largest from December through April, when inflow sediment loads and reservoir biomass levels were at a minimum. The maximum Secchi-disk depth of $9.75 \mathrm{~m}$ occurred in March 1986 at transect 7. Secchi-disk depths decreased between May through August as inflow sediment loads and reservoir biomass increased. During this period, Secchi-disk depths ranged from 2 to $4 \mathrm{~m}$. In the fall, Secchi-disk depths remained small $(2-3 \mathrm{~m})$; possibly as a result of 
the resuspension of sediment and detritus within the water column during fall turnover.

Turbidity measurements were used as a semiquantitative method of evaluating the distribution and transport of particulate matter that is input from the river into the reservoir. Turbidity measurements indicate most of the particulate matter settles from the reservoir water column within $5 \mathrm{mi}$ of the point where the Arkansas River enters the reservoir. Some particulate matter was transported through the entire reservoir during the summer when the reservoir was strongly stratified and streamflow in the Arkansas River was large and entering the reservoir as underflow.

Dissolved-oxygen concentrations near the reservoir surface generally were near saturation or supersaturated throughout the year. During the summer, dissolved-oxygen concentrations decreased with increasing depth. Anoxic conditions were measured on four occasions in 1986 through 1989. The most extensive period of anoxia was in August 1988 and occurred at sites nearest the dam, when the bottom $12 \mathrm{ft}$ of site $6 \mathrm{C}$ and the bottom 30 feet of site 7B were completely anoxic. Fall turnover typically redistributed dissolved oxygen throughout the water column and resulted in well-oxygenated conditions throughout the reservoir from September or October through the spring. The $\mathrm{pH}$ of water in the reservoir typically ranged from 7.5 to 9.0. Values of $\mathrm{pH}$ vary in the reservoir because of photosynthesis by phytoplankton in the epilimnion and plant and animal respiration in the metalimnion and hypolimnion. Generally, $\mathrm{pH}$ values were largest near the reservoir surface and decreased with increasing depth.

Calcium, sulfate, and bicarbonate are the major dissolved constituents in Pueblo Reservoir. Dissolvedsolids concentrations in the reservoir primarily are affected by dissolved-solids concentrations in the inflow from the Arkansas River. Concentrations in the reservoir are smallest in May through August, when streamflows are large and concentrations are small in the Arkansas River. Concentrations in the reservoir increase in September through April, as streamflows decrease and concentrations in the Arkansas River increase. During 1986 through 1987, the median dissolved-solids concentrations at the reservoir inflow and outflow were 224 and $262 \mathrm{mg} / \mathrm{L}$, respectively. A statistical analysis of dissolved-solids concentrations indicated the apparent increase in dissolved-solids concentrations between the inflow and outflow was not significantly different.

Concentrations of the major nutrients, nitrogen and phosphorus, varied within the reservoir. The processes that most likely affect nutrient distribution are uptake by phytoplankton near the surface, sedimenta- tion of particulate matter, and nutrient flux from the bottom sediments to the water column. In 1986 through 1989, the median dissolved inorganic nitrogen concentration ranged from 0.07 to $0.30 \mathrm{mg} / \mathrm{L}$ in May through September and from 0.17 to $0.24 \mathrm{mg} / \mathrm{L}$ in October through April. Concentrations were smaller near the surface than near the bottom in May through September, but in October through April, concentrations did not vary much between the surface and bottom. Concentrations varied only slightly between the reservoir inflow and outflow. The median concentration of total phosphorus ranged from 0.015 to $0.053 \mathrm{mg} / \mathrm{L}$ in May through September and from 0.012 to $0.039 \mathrm{mg} / \mathrm{L}$ in October through April. Total phosphorus concentrations typically were larger near the reservoir bottom than near the reservoir surface, probably because of settling of particulate matter, underflow of the Arkansas River inflow, and releases from the bottom sediments. A substantial decrease in dissolved-orthophosphorus concentrations near the reservoir surface between the inflow and outflow indicates phosphorus uptake by phytoplankton may contribute substantially to the overall decrease in total phosphorus concentrations in the reservoir. An analysis of nutrient loads in the reservoir inflow and outflow indicates the reservoir retained about 35 percent (359 tons) of the total nitrogen load and about 83 percent (203 tons) of the total phosphorus load for 1986 and 1987. An analysis of nutrient flux rates from the reservoir bottom sediments to the water column indicates nutrient flux may contribute significant nitrogen and phosphorus loads to the reservoir. The mean flux rate for inorganic nitrogen was about $30 \mathrm{mg} / \mathrm{m}^{2} /$ day. The mean flux rate for inorganic phosphorus was about $0.44 \mathrm{mg} / \mathrm{m}^{2} /$ day. Absolute concentrations of biologically available nitrogen and phosphorus near the reservoir surface and their mass ratios were evaluated to determine which nutrient, if any, was present at growth-limiting levels for phytoplankton. None of the 32 samples analyzed for dissolved inorganic nitrogen had concentrations less than the growth-limiting level for phytoplankton $(0.020 \mathrm{mg} / \mathrm{L})$. Of the samples collected and analyzed for dissolved orthophosphorus, 36 percent of the samples at site $3 B$ in the upstream and of the reservoir, 73 percent of the samples at site $5 \mathrm{C}$ near the middle of the reservoir, and 64 percent of the samples at site 7B near the dam had concentrations less than or equal to that which limits phytoplankton growth $(0.010 \mathrm{mg} / \mathrm{L})$. Twenty-eight of the 32 samples collected and analyzed for mass ratios of biologically available nitrogen and phosphorus $(\mathrm{N}: \mathrm{P})$ had $\mathrm{N}: \mathrm{P}$ values greater than 8 , a level that indicates phosphorus may be a limiting nutrient to phytoplankton growth. 
Barium, iron, manganese, and zinc are the trace elements that occurred in the largest concentrations in water samples collected from Pueblo Reservoir. Traceelement concentrations in Pueblo Reservoir vary primarily because of: (1) seasonality of trace-element concentrations in the Arkansas River, (2) settling of particulate matter, and (3) flux of trace elements from the reservoir bottom sediments. The flux of iron and manganese from bottom sediments can contribute substantial loads to the reservoir. Flux rates for iron and manganese were estimated to equal about 18,700 and $19,700 \mu \mathrm{g} / \mathrm{m}^{2} /$ day, respectively, during periods of low dissolved-oxygen concentrations. Depending on the stratification and mixing conditions present at the time, the trace elements released from the bottom sediments may be released at the dam, distributed throughout the water column, or resettle to the bottom sediments. The recommended aquatic-life criteria for total-recoverable iron $(1,000 \mu \mathrm{g} / \mathrm{L})$ and the public water-supply standard for dissolved-manganese concentrations $(50 \mu \mathrm{g} / \mathrm{L})$ were exceeded on several occasions during the summer. Elevated concentrations of total-recoverable iron and dissolved manganese in the Arkansas River during summer runoff contributed to the exceedances in the upper part of the reservoir, and flux of manganese from bottom sediments during periods of low or depleted dissolved-oxygen concentrations contributed to exceedances in the deeper, downstream part of the reservoir. Bottom-sediment samples analyzed for trace elements indicate lead, mercury, and zinc concentrations in the bottom sediments are elevated relative to geochemical baselines for soils in the Western United States. Lead, mercury, and zinc are common constituents in mine drainage and may have been transported from mined areas in the upper Arkansas River Basin and concentrated in the bottom sediments.

In Pueblo Reservoir, median concentrations of total organic carbon (TOC) ranged from 3.1 to $4.5 \mathrm{mg} / \mathrm{L}$ in May through September and from 2.5 to $3.5 \mathrm{mg} / \mathrm{L}$ in October through April. Concentrations typically decreased downstream from the reservoir inflow because of settling of particulate organic carbon (POC). The seasonal variability is caused by larger TOC concentrations in the Arkansas River inflow during spring and summer runoff and increased rates of primary productivity within the reservoir during the summer.

Seven of the 31 water samples collected from Pueblo Reservoir and analyzed for gross-alpha radioactivity of dissolved solids exceeded $5 \mathrm{pCi} / \mathrm{L}$ (as natural uranium), the level at which additional radionuclide analyses are recommended for drinking-water supplies. Median gross-alpha radioactivity of dissolved solids increased from $5.2 \mu \mathrm{g} / \mathrm{L}$ (as natural uranium) at site 1B in the upstream end of the reservoir to $6.9 \mu \mathrm{g} / \mathrm{L}$ near the surface and $7.9 \mu \mathrm{g} / \mathrm{L}$ near the bottom at site $7 \mathrm{~B}$ nearest the dam. Gross-alpha radioactivity of the suspended solids decreased from $4.5 \mu \mathrm{g} / \mathrm{L}$ (as natural uranium) at site $1 \mathrm{~B}$ in the upstream end of the reservoir to less than $0.4 \mu \mathrm{g} / \mathrm{L}$ at site $7 \mathrm{~B}$ nearest the dam. Settling of particulate matter probably contributed to the decrease in suspended gross-alpha radiation. Potential sources of gross-alpha radiation in Pueblo Reservoir include the weathering of exposed uranium ore deposits in the upper Arkansas River Basin and uranium milling operations near Canon City.

Biological data collected from Pueblo Reservoir, which included chlorophyll $a$ and phytoplankton densities and biovolumes, indicate phytoplankton distribution varies seasonally and spatially. During the winter, the median chlorophyll $a$ concentrations decreased from about $4 \mu \mathrm{g} / \mathrm{L}$ in the upstream part of the reservoir to about $1 \mu \mathrm{g} / \mathrm{L}$ in the downstream part of the reservoir. During the spring, the median chlorophyll $a$ concentrations decreased from about $6 \mu \mathrm{g} / \mathrm{L}$ in the upstream part of the reservoir to about $1.5 \mu \mathrm{g} / \mathrm{L}$ in the downstream part of the reservoir. During the summer, the median chlorophyll $a$ concentrations were similar (about $4 \mu \mathrm{g} / \mathrm{L}$ ) throughout the reservoir. During the fall, the median chlorophyll $a$ concentrations decreased from about $9 \mu \mathrm{g} / \mathrm{L}$ in the upstream part of the reservoir to about $2.5 \mu \mathrm{g} / \mathrm{L}$ in the downstream part of the reservoir. Although chlorophyll $a$ concentrations tended to be larger in the upstream part of the reservoir during the winter, spring, and fall, a statistically significant longitudinal difference was detected only during the fall.

Phytoplankton densities and biovolumes measured during the winter, spring, and fall generally were indicative of a small to moderate algal biomass. Phytoplankton production tended to be largest during the summer. During the summer, phytoplankton densities and biovolumes generally were indicative of a moderate to large algal biomass. However, excessive algal production and biomass periodically occurred during the spring, summer, and fall. Three species of phytoplankton that are specifically associated with tasteand-odor problems in drinking water were identified on several occasions in water samples collected from Pueblo Reservoir.

Reservoir operations and hydrodynamics can substantially affect processes that affect reservoir water quality. Stratification, underflow, and hypolimnetic withdrawals affect concentrations of dissolved solids, availability of nutrients, and concentrations of metals in the reservoir. Stratification impedes the mixing of epilimnetic and hypolimnetic waters, and the prevalent underflow that occurs during the summer results in a 
decrease in the potential dilution of inflowing river water with reservoir water. The underflow also decreases the maximum available nutrient load to the euphotic zone that can, in turn, offset the maximum algal growth potential. Increased dissolved-solids, nutrient, and metal concentrations that occur in the hypolimnion during the summer are partially offset by hypolimnetic withdrawals.

\section{SELECTED REFERENCES}

American Public Health Association, American Water Works Association, and Water Pollution Control Federation, 1985, Standard methods for examination of water and wastewater (16th ed.): Washington, D.C., American Public Health Association, 1,268 p.

Ball, J.W., and Nordstrom, D.K., 1991, User's manual for WATEQ4F, with revised thermodynamic data base and test cases for calculating speciation of major, trace, and redox elements in natural waters: U.S. Geological Survey Open-File Report 91-183, 193 p.

Britton, L.J., Averett, R.C., and Ferreira, R.F., 1975, An introduction to the processes, problems, and management of urban lakes: U.S. Geological Survey Circular 601-K, 22 p.

Britton, L.J., and Gaggiani, N.G., 1987, Water-quality assessment of Arvada Reservoir, Denver metropolitan area, Colorado: U.S. Geological Survey WaterResources Investigations Report 87-4107, 66 p.

Britton, L.J., and Greeson, P.E., eds., 1989, Methods for collection and analysis of aquatic biological and microbiological samples: U.S. Geological Survey Techniques of Water-Resources Investigations, book 5, chap. A4, $363 \mathrm{p}$.

Cain, Doug, 1987, Relations of specific conductance to streamflow and selected water-quality characteristics of the Arkansas River basin, Colorado: U.S. Geological Survey Water-Resources Investigations Report 87-4041, 93 p.

Callender, Edward, Ficklin, W.H., Kimball, B.A., and Edelmann, P.R., 1988, Heavy-metal geochemistry of sediments in the Pueblo Reservoir, Colorado, 1988, in Mallard, G.E., ed., U.S. Geological Survey Toxic Substances Hydrology Program-proceedings of the technical meeting, Phoenix, Ariz., September 26-30, 1988: U.S. Geological Survey Water-Resources Investigations Report 88-4220, p. 81-91.

Carlson, R.E., 1977, A trophic state index for lakes: Limnology and Oceanography, v. 22, no. 2, p. 361-369.

Clark, J.W., Viessman, W., Jr., and M.J. Hammer, 1977, Water supply and pollution control (3rd ed.): New York, Harper and Row, 857 p.
Cole, T.M., and Hannan, H.H., 1990, Dissolved-oxygen dynamics, in Reservoir limnology: ecological perspectives: New York, John Wiley \& Sons, Inc., p 71-108.

Colorado Department of Health, 1990, Classifications and numeric standards for the entire Arkansas River basin: Denver, Colorado Department of Health, Water Quality Control Commission, 92 p.

Cooke, G.D., Welch, E.B., Peterson, S.A., and Newroth, P.R., 1986, Lake and reservoir restoration: Boston, Ann Arbor Science, 392 p.

Crouch, T.M., Cain, Doug, Abbott, P.O., Penley, R.D., and Hurr, R.T., 1984, Water-resources appraisal of the Upper Arkansas River basin from Leadville to Pueblo, Colorado: U.S. Geological Survey Water-Resources Investigations Report 82-4114, 123 p.

Edelmann, Patrick, 1988, Reconnaissance of water quality of Pueblo Reservoir, Colorado-May through December 1985: U.S. Geological Survey Water-Resources Investigations Report 88-4118, 53 p.

Edelmann, Patrick, Scaplo, J.A., Colalancia, D.A., and Elson, B.B., 1991, Compilation of water-quality data for Pueblo Reservoir and the upper Arkansas River basin, Colorado, 1985-87: U.S. Geological Survey Open-File Report 91-506, 409 p.

Elder, J.F., 1988, Metal biogeochemistry in surface-water systems-a review of principles and concepts: U.S. Geological Survey Circular 1013, 43 p.

Federal Water Pollution Control Administration, 1968, Water-quality control study - the Fryingpan Arkansas project-Arkansas River subbasin, Colorado: U.S. Bureau of Reclamation, I-1 through C-20.

Feltz, H.F., Duncan, S.S., and Zepp, A., eds., 1985, National Water Quality Laboratory Services Catalog: U.S. Geological Survey Open-File Report 86-232.

Ford, D.E., 1990, Reservoir transport processes, in Reservoir Limnology: ecological perspectives: New York, John Wiley \& Sons, Inc., p 15-42.

Fishman, M.J., and Friedman, L.C., 1985, Methods for determination of inorganic substances in water and fluvial sediments: U.S. Geological Survey Open-File Report 85-0495, 709 p.

Goldman, C.R., and Horne, A.J., 1983, Limnology: New York, McGraw-Hill, $463 \mathrm{p}$.

Gordon, J.A., and Skelton, B.A., 1977, Reservoir metalimnion oxygen demands: Proceedings at the American Society of Civil Engineers, v. 103, no. EE6, p. 1001-1011.

Greeson, P.E., 1982, An annotated key to the identification of commonly occurring and dominant genera of algae observed in the phytoplankton of the United States: U.S. Geological Survey Water-Supply Paper 2079, $138 \mathrm{p}$. 
Helsel, Dennis, and Cohn, Tim, 1988, Estimation of descriptive statistics for multiply-censored water-quality data: Water Resources Research: v. 24, p. 1997-2004.

Hem, J.D., 1985, Study and interpretation of the chemical characteristics of natural water (3rd ed.): U.S. Geological Survey Water-Supply Paper 2254, 263 p.

Horowitz, A.J., Elrick, K.A., von Guerard, Paul, Young, N.O., Buell, G.R., and Miller, T.L., 1992, The use of automatically collected point samples to estimate suspended-sediment and associated trace-element concentrations for determining annual mass transport, in Bogan, J., Walling, D.E., and Day, T., eds., Erosion and monitoring programmes in river basins, IAHS Publication 210, p. 209-218.

Hutchinson, G.E., 1957, A treatise on limnology, v. 1Geography, physics, and chemistry: New York, John Wiley, $1,1015 \mathrm{p}$.

Iman, R.L., and Conover, W.J., 1983, A modern approach to statistics: New York, John Wiley and Sons, 497 p.

Kimball, B.A., Bencala, K.E., and McKnight, D.M., 1988, Research on metals in acid mine drainage in the Leadville, Colorado, area, in Mallard, G.E., ed., U.S. Geological Survey Toxic Substances Hydrology Programproceedings of the technical meeting, Phoenix, Ariz., September 26-30, 1988: U.S. Geological Survey Water-Resources Investigations Report 88-4220, p. 65-70.

La Bounty, J.F., Sartoris, J.J., Klein, L.D., Monk, E.F., and Salman, H.A., 1975, Assessment of heavy-metals pollution of the upper Arkansas River of Colorado: U.S. Bureau of Reclamation, REC-ERC-75-5, 123 p.

Mallevialle, Joel, and I.H. Suffet, eds., 1987, Identification and treatment of tastes and odors in drinking water: Denver, Colo., American Water Works Association, $292 \mathrm{p}$.

Miles, D.L., 1977, Salinity in the Arkansas Valley of Colorado: Denver, Colo., U.S. Environmental Protection Agency, Region 8, 80 p.

Moss, Brian, 1980, Ecology of fresh waters: New York, John Wiley, $332 \mathrm{p}$.

Moran, R.E., and Wentz, D.A., 1974, Effects of metal-mine drainage on water quality in selected areas of Colorado, 1972-73: Denver, Colorado Board Water Resources Circular no. 25, 250 p.

Mueller, D.K., DeWeese, L.R., Garner, A.J., and Spruill, T.B., 1991, Reconnaissance investigation of water quality, bottom sediment, and biota associated with irrigation drainage in the middle Arkansas River basin, Colorado and Kansas, 1988-89: U.S. Geological Survey Water-Resources Investigations Report 91-4060, $84 \mathrm{p}$.

Organisation for Economic Co-operation and Development, 1982, Eutrophication of waters-monitoring, assessment and control: Paris, $154 \mathrm{p}$.
Palmer, C.M., 1977, Algae and water pollution-an illustrated manual on the identification, significance, and control of algae in water supplies and in polluted water: U.S. Environmental Protection Agency, EPA-600/977-036, $124 \mathrm{p}$.

Redfield, A.C., Ketchum, B.H., and Richards, F.A., 1963, The influence of organisms on the composition of sea water, in Hill, M.N., ed., The Sea, v. 2, WileyInterscience, New York, p. 26-77.

Roline, R.A., and Boehmke, J.R., 1981, Heavy metals pollution of the upper Arkansas River, Colorado, and its effects on the distribution of the aquatic microfauna: U.S. Bureau of Reclamation, REC-ERC-81-15, 71 p.

Ryding, S.O., and Rast, Walter, 1989, Control of eutrophication of lakes and reservoirs, v. 1, United Nations Educational, Scientific, and Cultural Organization (UNESCO) Programme on Man and the Biosphere (MAB): United Kingdom, Parthenon Press, 314 p.

SAS Institute Inc., 1985, SAS user's guide-statistics (version 5 edition): Cary, N.C., SAS Institute Inc., 956 p.

Shacklette, H.T., and Boerngen, J.G., 1984, Element concentration in soils and other surficial materials of the conterminous United States: U.S. Geological Survey Professional Paper 1270, $105 \mathrm{p}$.

Seppovaara, A., 1971, The effect on fish of the mass development of brackish water plankton: Aqua Fennica, p. 118-129.

Thatcher, L.L., Janzer, V.J., and Edwards, K.W., eds., 1977, Methods for determination of radioactive substances in water and fluvial sediments: U.S. Geological Survey Techniques of Water-Resources Investigations, book 5, chap. A5, $95 \mathrm{p}$.

Thibodeaux, L.J., 1979, Chemodynamics: New York, John Wiley, $510 \mathrm{p}$.

Thurman, E.M., 1986, Organic geochemistry of natural waters: Dordrecht, The Netherlands, Martinus Nijhoff/ Dr. W. Junk Publishers, 497 p.

Ugland, R.C., Cochran, B.J., Ebling, J.L., and Steger, R.D., 1989, Water-resources data, Colorado, water year 1988-v. 1, Missouri River basin, Arkansas River basin, and Rio Grande basin: U.S. Geological Survey Water-Data Report CO-88-1, 411 p.

Ugland, R.C., Cochran, B.J., Hiner, M.M., and Steger, R.D., 1991, Water-resources data, Colorado, water year 1990 — v. 1, Missouri River basin, Arkansas River basin, and Rio Grande basin: U.S. Geological Survey Water-Data Report CO-90-1, 489 p.

U.S. Bureau of Reclamation, 1972, Pueblo Dam and Reservoir final environmental impact statement: Denver, Final Environmental Statement FES-72-16, 81 p.

U.S. Environmental Protection Agency, 1986, Advance notice of proposed rulemaking, national primary drinking water regulations; radionuclides (section 141.50 of 
part 141): U.S. Federal Register, v. 51, no. 189, September 30, 1986, p. 34,836-34,846.

1986, Quality criteria for water: EPA 440/5-86-001, $256 \mathrm{p}$.

Walker, W.W. Jr., 1983, Significance of eutrophication in water supply reservoirs: American Water Works Association, p. 38-42.

Wentz, D.A., 1974, Effect of mine drainage on the quality of streams in Colorado, 1971-72: Denver, Colorado Water Conservation Board Water Resources Circular $21,117 \mathrm{p}$.
Wershaw, R.L., Fishman, M.J., Grabbe, R.R., and Lowe, L.E., eds., 1983, Methods for the determination of organic substances in water and fluvial sediments: U.S. Geological Survey Techniques of WaterResources Investigations, book 5, chap. A3, 173 p.

Wetzel, R.G., 1983, Limnology: Philadelphia, W.B. Saunders, $767 \mathrm{p}$.

Wunderlich, W.O., 1971, The dynamics of density-stratified reservoirs in Reservoir Fisheries and Limnology:

American Fisheries Society, Special Publication no. 8, p. 219-230. 